九州大学学術情報リポジトリ

Kyushu University Institutional Repository

\title{
Studies On The Crab-Shaped Anomura Of Nippon And Adjacent Waters
}

Miyake, Sadayoshi

Zoological Laboratory, Kyusyu Imperial University

https://doi.org/10.5109/22596

出版情報 : 九州大学大学院農学研究院紀要. 7 (3)，pp.49-158，1943-05. Kyushu Imperial University バージョン：

権利関係 : 
Journal of the Department of Agriculture, Kyüsyü Imperial University, Vol. 7, No. 3, May 5th, 1943

\title{
STUDIES ON THE CRAB-SHAPED ANOMURA OF NIPPON AND ADJACENT WATERS ${ }^{1}$
}

\author{
Sadayoshi MIYAKE
}

\section{INTRODUCTION}

The present paper comprises the crab-shaped Anomura of Nippon and adjacent waters. While the Nipponese Porcellanid fauna does not seem to have been investigated thoroughly, a number of fragmental accounts on the Porcellanidae were reported by a few authors in the past.

In 1849, DE HAAN described Petrolisthes japonicus, under the name of Porcellana japonica from Nippon. This is the first record of the family as occurring in Nippon.

STIMPSON may be called the pioneer worker on the Porcellanidae; he described the following six species. 1. Petrolisthes lamarckii (as Petrolisthes speciosus), 2. Petrolisthes tomentosus (as Petrolisthes pubescens), 3. Petrolisthes hastatus, 4. Petrolisthes japonicus, 5. Pachycheles stevensii, 6. Porcellana armata (as Porcellana latifrons).

Miers (1879) mentioned one species, Porcellana spinulifrons from Strait of Tyōsen, but this seems to me to be merely a young form of Porcellana serratifrons.

In 1892, ORTMANN reported the following five more species from Nippon: 1. Petrolisthes militaris, 2. Pisosoma sculptum, 3. Raphidopus ciliatus, 4. Porcellana pulchra, 5. Polyonyx carinatus. The last mentioned species is at present indeterminable.

1) Contributions from the Zoological Laboratory, Kyūsyū Imperial University, No. 161 
Three more species were described by BaLss (1913), namely, 1. Petrolisthes boscii, 2. Petrolisthes coccineus (as Petrolisthes pubescens), 3. Pachycheles balssi (as Pachycheles pubescens).

Yокоча (1933) recorded one species Porcellanella picta from Ise Bay.

In 1939, Melin described three more species from Ogasawara Islands: 1. Petrolisthes inermis (as Petrolisthes teres), 2. Petrolisthes indicus (as Petrolisthes securiger), 3. Pisosoma fronto (as Pachycheles fronto).

Recently (1937-'42) the writer described 11 more species and one variety in the series of five papers. 1. Petrolisthes penicillatus, 2. Petrolisthes fimbriatus, 3. Petrolisthes moluccensis, 4. Neopetrolisthes ohshimai, 5. Porcellana ornata, 6. Porcellana nitida, 7. Porcellana murakamii, 8. Porcellana melissa, 9. Porcellanella triloba, 10. Polyonyx utinomii (as Polyonyx asiaticus), 11. Polyonyx biunguiculatus and Petrolisthes lamarckii var. rufescens.

Such is the present status of our knowledge concerning the Porcellanidae of Nippon. After examining the materials from various localities of our country, I have found 36 species and one variety of the family, of which one seems to be new to science and three new to the fauna. Further, there are some additional localities for known species.

The species of this family frequently show a good deal of variation, hence so many cases of misidentification as seen in the list given above. Difficulties as to species demarcation thus often arise, and I have felt it desirable of establishing some definite structures for the purpose, such as first peduncle of antennule, basal peduncles of antenna, merus and sternum of third maxilliped, armature or spinulation of cheliped and ambulatory legs and shape of telson.

The materials here dealt with came from the following sources: (i) the collections in the Zoological Laboratory and the Amakusa Marine Biological Laboratory of the Kyūsyü Imperial University, made from time to time by Prof. H. OHshima, Assist. Prof. H. Ikeda, Dr. K. Baba, Messrs. S. Murakami, T. Kawahara, K. YASUMOTO and the writer, (2) the collection of the Onomiti Marine Biological Laboratory made by Assist. Prof. I. TAKI, (3) some typical specimens from the Misaki Marine Biological Station col- 
lected by Assist. Prof. M. YERI, (4) the collection of the Kominato Marine Laboratory attached to the Imperial Fisheries Bureau, (5) the collection of the Tōkyō Science Museum, (6) the collection in the Saito Hō-on Kai Museum submitted for study by Dr. S. OfuchI, (7) some specimens from the Asamusi Marine Biological Laboratory through the courtesy of Dr. N. ABE, (8) a private collection from Micronesia made by Prof. T. EsAKI of the Kyüsyū Imperial University, (9) some specimens from Australia, New Zealand and New Guinea collected by Mr. M. WARD of the Australian Museum, Sydney, (10) a rich material from Isigaki Island collected by Messrs. T. SENAHA and T. MASAKI, (11) collection from Palau Islands made by Messrs. S. Murakami, R. WADA, K. TAKahasi and the writer, (12) the material from Taiwan collected by Prof. H. OHshima, Assist. Prof. H. SATO, Messrs. N. Sasaki and H. Utinomi, (13) the material from Kōti collected by Mr. Z. IsıKAwA and (14) the material from Amami-Ösima collected by Mr. I. TAKEsITA.

I take this opportunity to express my gratitude for those gentlemen who have kindly assisted me in preparing this report. First, I wish to thank the Nippon Society for the Promotion of Scientific Research for a grant-in-aid. I am especially indebted to Professor Hiroshi OHshima who has provided me with facilities required for the pursuit of this work, and kindly looked through the manuscript. I express my hearty thanks to above-mentioned gentlemen, for placing their materials at my disposal. Acknowledgement is also due to Miss A. ZYōzimA, for drawing of some text-figures.

List of the species described in this paper

Page

1. Petrolisthes militaris (HELLER) .................... 56

2. Petrolisthes coccineus (OwEN) ........................ 59

3. Petrolisthes hastatus (STIMPSON) ..................... 62

4. Petrolisthes unilobatus Henderson ..................... 66

5. Petrolisthes indicus DE MAN ........................ 69

6. Petrolisthes japonicus (DE HAAN).................... 72

6.' Petrolisthes elongatus (H. Milne-Edwards) .......... 77

7. Petrolisthes inermis HASWELL ........................ 80

8. Petrolisthes penicillatus (HELLER) …............... 83

9. Petrolisthes tomentosus (DANA) .................... 85 
10. Petrolisthes fimbriatus BORRADAILE ................. 89

11. Petrolisthes boscii (Audouin et SAvignY) .............. 90

12. Petrolisthes masakii sp. nov. ........................ 93

13. Petrolisthes asiaticus (LEACH) ......................... 95

14. Petrolisthes moluccensis (DE MAN) .................. 97

15. Petrolisthes lamarckii (LEACH) ....................... 98

15a. Petrolisthes lamarckii var. rufescens (Heller)........ 100

16. Neopetrolisthes ohshimai MrYake .................... 101

17. Pachycheles stevensii STIMPSON ...................... 103

18. Pachycheles balssi nom. nov. ....................... 106

19. Pisosoma sculptum (H. MILNE-EDWARDS) ............. 110

20. Pisosoma pisum (H. MiLnE-EDWARDs) ............... 112

21. Pisosoma fronto (MELIN) ............................ 113

22. Porcellana orna STIMPSON ............................ 118

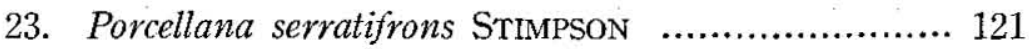

24. Porcellana pulchra STIMPSON ......................... 124

25. Porcellana armata DANA ............................ 127

26. Porcellana suluensis DANA .......................... 128

27. Porcellana nitida HASwELL ........................... 129

28. Porcellana murakamii MIYAKE ..................... 129

29. Porcellana melissa MrYAkE ........................... 131

30. Porcellanella triloba WHITE .............................. 134

31. Porcellanella picta STIMPSON ........................... 134

32. Polymyx sinensis STIMPSON ........................... 138

33. Polyonyx utinomii nom. nov. ........................ 141

34. Polyonyx carinatus ORTMANN ......................... 144

35. Polyonyx biunguiculatus STrMPSON ..................... 144

36. Raphidopus ciliatus Stimpson ....................... 146

\section{SYSTEMATIC}

Order Decapoda LATREILle 1806

Suborder Reptantia BoAs 1880

Tribe Anomura H. MILnE-EDwards 1832

Subtribe Galatheidea BoAs 1880

Superfamily Porcellanidea DE HAAN 1850

Family Porcellanidae DANA 1852

Body crab-like, carapace broadly ovate; the front usually trilobed, and the processes never of great length; first pair of legs 
chelate, broad and often flattened; fifth pair small and elevated, resting on the carapace; abdomen bent under and folded against the carapace; tail-fan well developed; female with two (or three) pairs of slender uniramous appendages borne on the fourth, fifth (and third) segments; male with a single pair on the second segment.

Key to the genera of the Porcellanidae

A) First peduncle of antenna short, not reaching the upper margin of carapace

B) Epimera entire, telson seven-jointed

C) Carapace rather depressed, eyes moderate in size, wrist more or less elongated, ambulatory legs a little compressed, propodus and dactylus spinulose on posterior margin ........... Petrolisthes

CC) Carapace strongly convex, eyes rather small, wrist very short, ambulatory legs subcylindrical, propodus and dactylus unarmed Neopetrolisthes

BB) Epimera separated from the larger anterior portion by a membranous interspace, telson five-jointed

C) Frontal margin concealed by pubescence, anterior margin of first peduncle of antennule spinulose, laminate crest of merus of third maxilliped slightly narrow, central plate of telson a little longer than that of Pisosoma.............. Pachycheles

CC) Frontal margin smooth, not pubescent, anterior margin of first peduncle of antennule undulated, laminate crest of merus of third maxiliped rather broad, central plate of telson broad .......

Pisosoma

AA) First peduncle of antenna much produced, and jointed to the margin of carapace, second peduncle placed at a distance from the orbit

B) Front prominent, trilobed or dentate, wrist very short

C) Carapace not longer than broad ........... Porcellana

CC) Carapace much longer than broad, with lateral margins almost parallel to each other...Porcellanella

BB) Frontal margin almost straight from above, carapace broader than long, wrist remarkably elongated 
C) Carapace subquadrate, cheliped rather thick, ambulatory legs short but robust, dactylus with unguicles Polyonyx

CC) Carapace subhexagonal, cheliped flattened, ambulatory legs slender, ciliated, dactylus almost straight with apex acute

Raphidopus

\section{Genus Petrolisthes STIMPSON}

Petrolisthes Stimpson 1858, p. 65; 1907, p. 181; Haswell 1882, p. 145; Henderson 1888, p. 104; ORTMANN 1897, p. 275 ; Schmitt 1921 , p. 178 ; MIYAKE 1942 , p. 333

Carapace depressed, subovate, front triangular, margin more or less undulated, toothed or entire; epimera (pleural, subbranchial, or lateral portions of carapace) entire; eyes rather large; first (basal or coxal) peduncle of antenna remarkably short, not reaching the upper margin of carapace; second or movable peduncle of antenna flattened and more or less cristate; chelipeds equal or subequal, broad and flattened; wrist or carpus more or less elongated and often provided with the teeth on inner (or anterior) margin; ambulatory legs with the dactylus short and robust, terminating in a single claw.

Type: Petrolisthes violaceus (GuÉRIN)

The species of Petrolisthes are very numerous, inhabiting the tropical and temperate zones in both oceans. They are strictly littoral inhabitants, and commonly found under rocks or in coral reef between tide-marks, in Nippon and adjacent waters.

Key to the species of Petrolisthes

A) Supra-ocular spine present

1. Lateral margin of carapace with two or three spines at the middle......................................... militaris

- Lateral margin of carapace without spine......... coccineus

AA) Supra-ocular spine wanting

B) Epibranchial spine wanting

C) Posterior margin of wrist prolonged at distal end into an acute spine

1. Anterior margin of wrist with three teeth... 
- Anterior margin of wrist with a single tooth at proximal end ................................. 2

2. The surfaces of carapace and legs smooth unilobatus

- Carapace and legs uneven or granulated indicus

CC) Posterior margin of wrist with two or three teeth; anterior margin of wrist with one tooth at proximal end

1. Carpus with one spinule above; propodus with five spinules below, and without hair on cutting margins of cheliped ............... 2

- Carpus without spinule above; propodus with four spinules below; fingers of cheliped with hairs along cutting margins inermis

2. Attains a large size, having rather broad chelipeds and legs; and inhabits only the Sea of New Zealand .................... elongatus

- Of a smaller size, having narrow cheliped; and commonly found in Nippon and adjacent waters..................................... japonicus

BB) Epibranchial spine present (excepting masakii and lamarckii var. rufescens)

C) Cheliped with long, fine hairs on outer margin of palm

1. Carapace covered with velvety tomentum, furnished with tufts of hair especially on hepatic, gastric and branchial regions...

penicillatus

- Carapace pubescent; outer margin of palm serrated proximally ..................... tomentosus

- Carapace pubescent sparsely; outer margin of palm simply crenulated fimbriatus

CC) Cheliped without hair on outer margin of palm

1. Carapace and cheliped with transverse, squamiform lines; wrist with three or more teeth on anterior margin $\ldots \ldots \ldots \ldots \ldots \ldots \ldots . . .2$

- Carapace almost smooth, wrist usually with three teeth 
2. Epibranchial spine present...................boscii

- Epibranchial spine wanting ................masakii

3. Merus spinulose on anterior margin ........ 4

- Merus without spinule on anterior margin... 5

4. With a single spinule at subdistal end of anterior margin .............................asiaticus

- With $3 \sim 6$ spinules on anterior margin .......................................... moluccensis

5. Epibranchial spine present ............. lamarckii

- Epibranchial spine wanting ....................

lamarckii var. rufescens

1. Petrolisthes militaris (HELLER)

Text-figs. 1-2.

Porcellana militaris Heller 1862, p. 523-Nicobars (Type-locality). .............. Heller 1865, p. 75-No new locality.

Porcellana (Petrolisthes) militaris DE M MN 1887, p. 410-Edam I., West coast of Java.

Petrolisthes militaris ORTMANN 1892, p. 523-Amami-Ösima.

........ ........ Henderson 1893, p. 427-Indian Ocean: Muttuwartu Par; Cheval Par; Rameswaram.

............... ORTMANN 1897, p. 289-No new locality.

........ ....... RATHBUN 1924, p. 29--North Australia: Cape Jaub.

............... LAỤRIE 1926, p. 142-Indian Ocean: Cargados

Carajos; Chagos.

............... Yokoya 1933, p. 70-Tanega-sima.

Petrolisthes annulipes Miers 1884, p. 270, P1. 29, fig. B, b; p. 558-

Seychelles; N. E. Australia.

Carapace slightly convex in both directions and a little longer than broad. Anterior margin of front furnished with microscopical teeth closely. A supra-ocular spine present, but lateral frontal margins simply crenulated and not spinulose. Posto-ocular lobe produced laterally and dentate as in anterior margin of front. Lateral margin of carapace ornamented with three spines behind two epibranchial spines, one of them on normal position, the other on the branchial region; dorsal surface ornamented with transverse striae bordering microcospical hairs anteriorly.

First peduncle of antennule longer than broad, dorsal surface smooth; its anterior margin dentate, a notch present near the 
flagellum. First peduncle of antenna longer than broad, anterior margin provided with a laminate crest; the anterior margin of

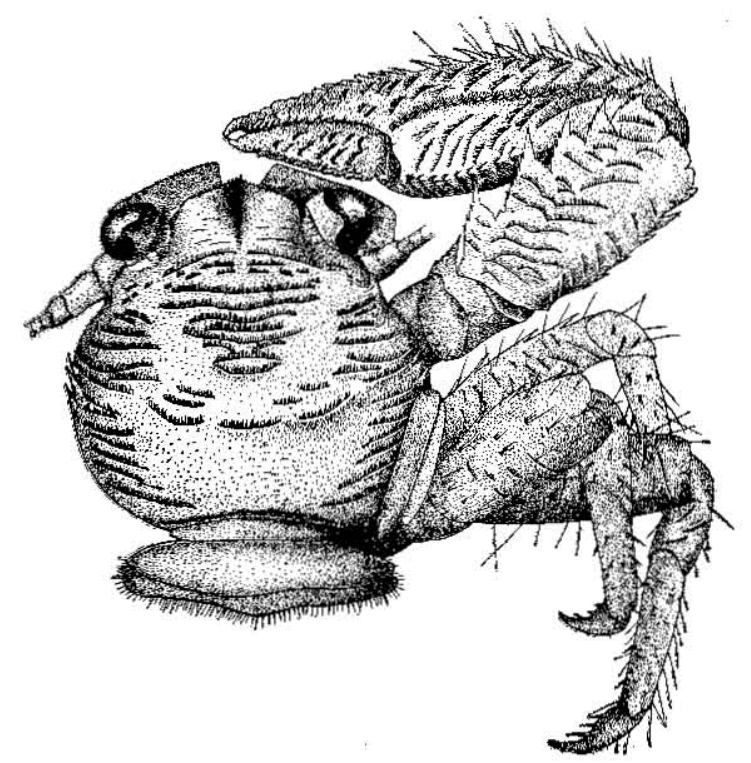

Fig. 1. Petrolisthes militaris (HrLLfe), male, $\times 7.5$.

second peduncle furnished with granules and hairs. Third maxilliped: Merus triangular, furnished with short transverse ridges on ventral surface, distal margin undulated; inner margin of carpus not produced, the ventral surface furnished with a granulated line along the submarginal border, which is ornamented with microscopical hairs.

Chelipeds unequal, ornamented with transverse ridges on dorsal surface; arm (or merus) has a long tooth at the distal end of anterior margin; wrist (or carpus) measures nearly three-fourths the carapace, its length is greater than twice of breadth, the anterior margin armed with four or five teeth in our collection, the posterior margin with two or three teeth distally; palm a little longer than wrist, and furnished with two longitudinal ridges in addition to the transverse ridges, one is near the inner margin, the other is at the middle, its outer margin armed with spinules which gradually pass into microscopical granules. There is no gap between fingers. 
Ambulatory legs a little hairy; merus provided with spines on the anterior margin; the posterior margin of first two pairs armed with an acute spine at distal end of posterior margin; the corresponding part of third pair unarmed; propodus of first two pairs provided with three spinules along the logitudinal axis and two similar at the distal end of the posterior margin; that of third pair provided with two spinules along the longitudinal axis and two spinules at the corresponding position; dactylus of first three pairs armed with three spinules on the posterior margin. Telson of abdomen five-jointed.

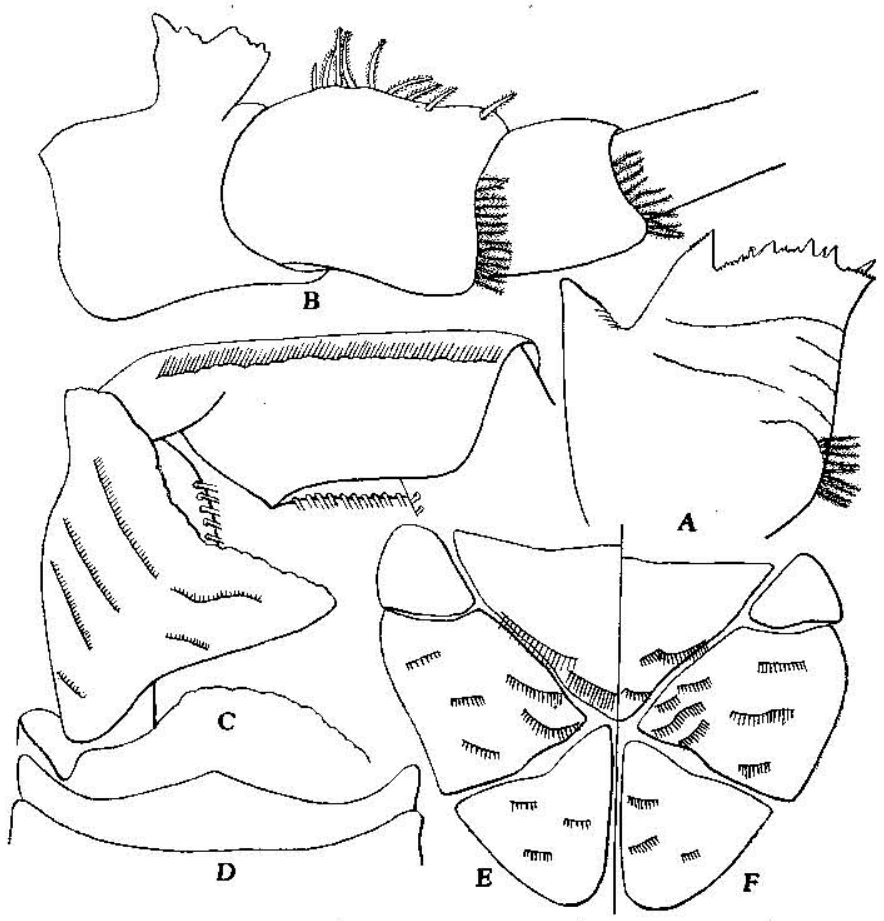

Fig. 2. Petrolisthes militaris (H:LLER).

A First peduncle of left antennule, ventral view, $\times 40$, B Basal peduncles of right antenna, ventral view, $\times 40, \quad \mathrm{C}$ Merus and carpus of third maxilliped of right side, ventral view, $\times 23$, D Sternum of third maxilliped of female, $x 25$, E Telson of male, $\times 25, F$ Same of female, $\times 25$.

Habitat: Found in coral reefs.

Material examined: 
Arafura Sea: West of Bathurst I., 1 ô, 3 ovig. \&; Aug. 1939 (collected by Mr. S. WADA).

Papua, New Guinea; 1 ovig. \& (sent by Mr. M. WARD).

Dimensions (in $\mathrm{mm}$ ):

Length of carapace

\begin{tabular}{|c|c|c|c|}
\hline \multicolumn{2}{|c|}{$\begin{array}{c}\hat{\delta} \\
5.6 \\
5.3\end{array}$} & \multicolumn{2}{|c|}{$\begin{array}{c}\text { ovig. ㅇ } \\
6.0 \\
5.8\end{array}$} \\
\hline Left & Right & Left & Right \\
\hline 4.2 & 4.6 & missing & 4.5 \\
\hline 2.5 & 2.3 & $\ldots \ldots$ & 2.5 \\
\hline 5.7 & 7.0 & $\ldots .$. & 5.1 \\
\hline 3.0 & 3.5 & $\ldots \ldots$ & 3.0 \\
\hline 2.3 & 2.2 & $\ldots \ldots$ & 3.0 \\
\hline
\end{tabular}

Breadth of carapace

Length of wrist

Breadth of wrist

Length of palm

Breadth of palm

Length of movable finger

2.3

2.2

3.0

Distribution: Indian Ocean, Nicobars, Seychelles, Java, Philippines, North Australia, Amami-Ōsima, Tanegasima I.

\section{Petrolisthes coccineus (OWEN) \\ Text-figs. $3-4$.}

Porcellana coccinea OwEN 1839, p. 87, Pl. 26, figs. 1-2-Paumotu Is. Petrolisthes coccineus ORTMANN 1897, p. 288-Tahiti Is.

.............. Calman 1909, p. 706-Christmas Is.

............... LAURIE 1926, p. 143-Seychelles.

Porcellana barbata HeLleR 1862, p. 523-Nicobars.

Heller 1865 , p. 80 , Pl. 6, fig. 8-No new locality.

Petrolisthes barbatus DE MAN 1893, p. 196, Pl. 7, figs. 4, 4a-Flores.

Petrolisthes pubescens BALss 1913, p. 30, Pl. 1, fig. 2-Tusima I.; Kominato.

Petrolisthes nipponensis Mryake 1937, p. 213, text-figs. 2a-c; PI. 12,

fig. 1-Seto, Prov. Kii; Okinosima I., Hukuoka-ken; Tomioka, Amakusa; Kagosima-ken.

Carapace depressed, a little broader than long; upper surface pubescent, being furnished with squamiform granules in anterior half. Front triangular, with apex rounded, concave above and separated from the gastric region by a slightly elevated, transverse crest which is interrupted in the middle by the median frontal furrow. The supra-ocular spine present above the eye. The lateral margin very much expanded, and broadest at the middle. The epibranchial spine prominent above the second peduncle of antenna. 
The epimera ornamented with a longitudinal line of granules, and furnished with long hairs.

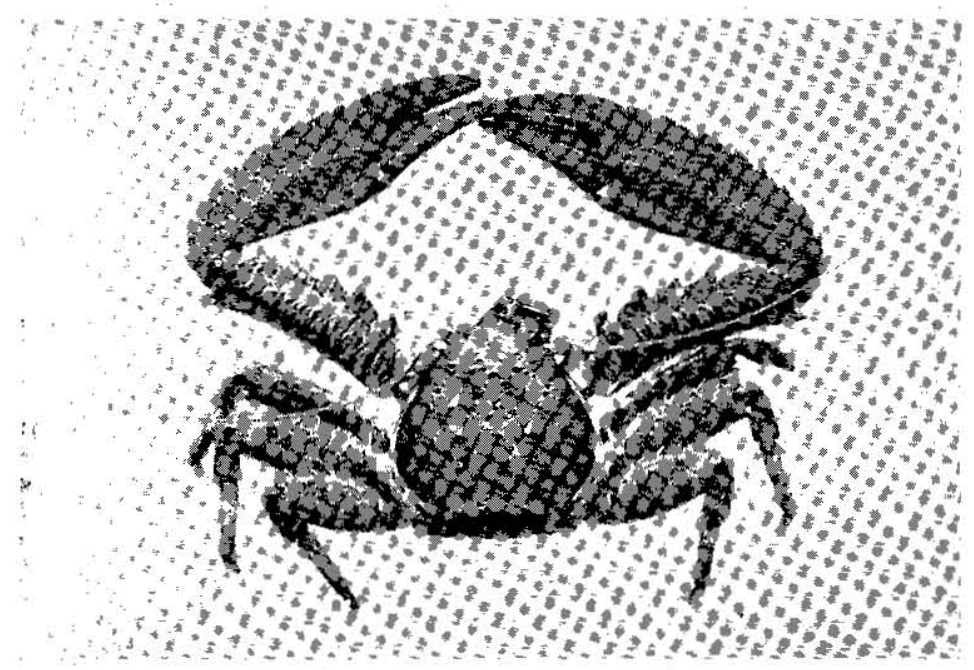

Fig. 3. Petrolisthes coccineus (OWEN), male, slightly enlarged.

First peduncle of antennule longer than broad; upper margin furnished usually with seven spinules, two of which on both lateral ends being very large and much produced, and separated from the other five spinules by a notch. The crest of second peduncle of antenna furnished with acuminate angle on the proximal end, with the margin undulated; third peduncle provided with a conical spine on anterior margin, its ventral surface furnished with two longitudinal ridges, while its dorsal surface with a few short transverse ridges. Merus and carpus of third maxilliped similar in shape to those in P. tomentosus. Ventral surface of merus with transverse striae, but here in this species carpus bears short longitudinal striae on ventral surface instead of having short setae as in $P$. tomentosus. Sternum of third maxilliped as figured (4E).

Chelipeds unequal; ischium prolonged in an acute tooth at its anterior extremity; arm has a long, prominent tooth at the anterior extremity, the posterior one prolonged in an acute tooth as in the ischium; there are two small but acute spines on the distal margin of arm, and moreover one spine before the named spines on upper side; wrist provided with three or four stout and acuminate teeth on anterior margin, the rugose posterior margin armed with two 
or three teeth at distal part; the anterior half of the upper surface of the wrist covered with flattened granules beneath short, soft hairs, which gradually pass into transverse, squamiform lines in the posterior half; the upper surface of palm covered with similar flattened granules beneath the hairs, palm armed with about ten spines on outer margin, and two spines on distal part of inner margin; fingers much shorter than palm, their tips crossing each other; movable finger ornamented with a longitudinal line of squamiform granules on upper surface.

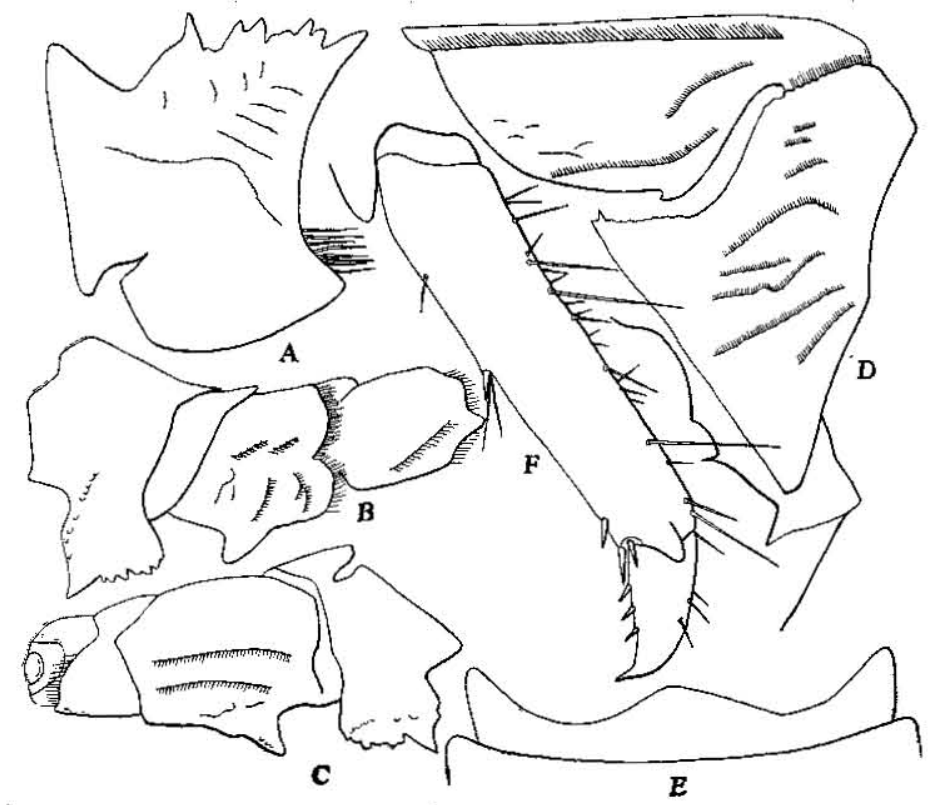

Fig. 4. Petrolisthes coccineus (Owlin).

A First peduncle of antennule, ventral view, $\times 12$, B Basal peduncles of left antenna, dorsal view, $\times 24$, C Ventral view of same, $\times 12, \quad \mathrm{D}$ Merus and carpus of third maxiliped of left side, $\times 12, \quad \mathrm{E}$ Sternum of third maxilliped of male, $\times 7.5, \quad$ F Distal part of ambulatory leg, $\times 7.5$.

Ambulatory legs are of a moderate length and are hairy; merus furnished with transverse, squamiform granules on upper surface beneath minute hairs, and armed with five to nine spines on anterior margin which is bordered with dense long hairs, posterior margin of merus of first two pairs armed with two spines at distal end, that of the third pair with a single spine; 
propodus armed with two spinules along the longitudinal axis and with two similar ones at the distal end of posterior margin; dactylus terminating in a black horny claw and provided with three spinules. Telson of abdomen seven-jointed, central plate rather broad.

Colour in life: Dorsal face reddish brown, ventral reddish, epimera greenish blue.

Habitat: Commonly found under rocks between tide-marks.

Material examined:

Seto, Prov. Kii, 2 命 ô, S. M. B. L., J. IX, Cat. No. 19, Apr. 3, 1936 (UTINOMI).

Prov. Tosa, 3 sิ ô, Oct. 8, 1941 (IsIKAWA).

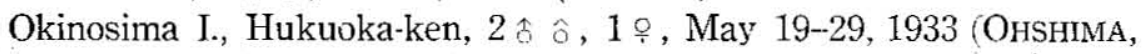
IKEDA and YASUMOTO).

Koura, Kagosima-ken, $1 \hat{o}$, May 1911, deposited in the Kagosima Museum.

Suō, Taiwan, 1 s , Nov. 4, 1932 (OHshima).

Dimensions (in $\mathrm{mm}$ ):

$$
\hat{\delta} \text { (Seto) }
$$

우 (Okinosima)

Length of carapace

Breadth of carapace

19.2

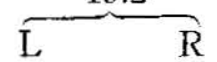

Length of chela

15.5

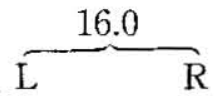

$24.5 \quad 25.5$

Breadth of palm

Length of wrist

18.0

$11.5 \quad 12.0$

Distribution : Seychelles, Nicobars, Christmas Is., Flores, Tahiti Is., Paumotu Is., Sandwich Is., Nippon: Kominato, Seto, Tosa,

Okinosima I., Amakusa, Kagosima, Taiwan.

\section{Petrolisthes hastatus StIMPson Text-figs. $5-6$.}

Petrolisthes hastatus StIMPSON 1858, p. 141; 1907, p. 184, P1. 22, fig. 4--Kikai-Zima; Amami-Ōsima.

............... ORTMANN 1892, p. 260-Amami-Ösima.

.............. LANCHES'TER 1900, p. 260-Pulau Satang, Malaysia.

............... MAKI and TutiYa 1923, p. 113, Pl. 11, fig. 3Suō, Taiwan.

GORDON 1935, p. 8-Sabong. 
Porcellana lamarckii H. MilnE-Edwards 1837, p. 251-Bismarck Is. Porcellana inermis HelleR 1865, p. 76, P1. 8, fig. 5-Nicobars. Porcellana (Petrolisthes) inermis DE MAN 1888a, p. 212-Owen I., Mergui Is.

$$
\text { DE MAN } 1888 \text { b, p. 409-Java. }
$$

Petrolisthes inermis DE MAN 1896, p. 373-Atjeh, North Sumatra. DE MAN 1902, p. 691, Pl. 23, fig. 36-Ternate, Moluccas.

\section{SendLer 1923, p. 41-Locality unknown.}

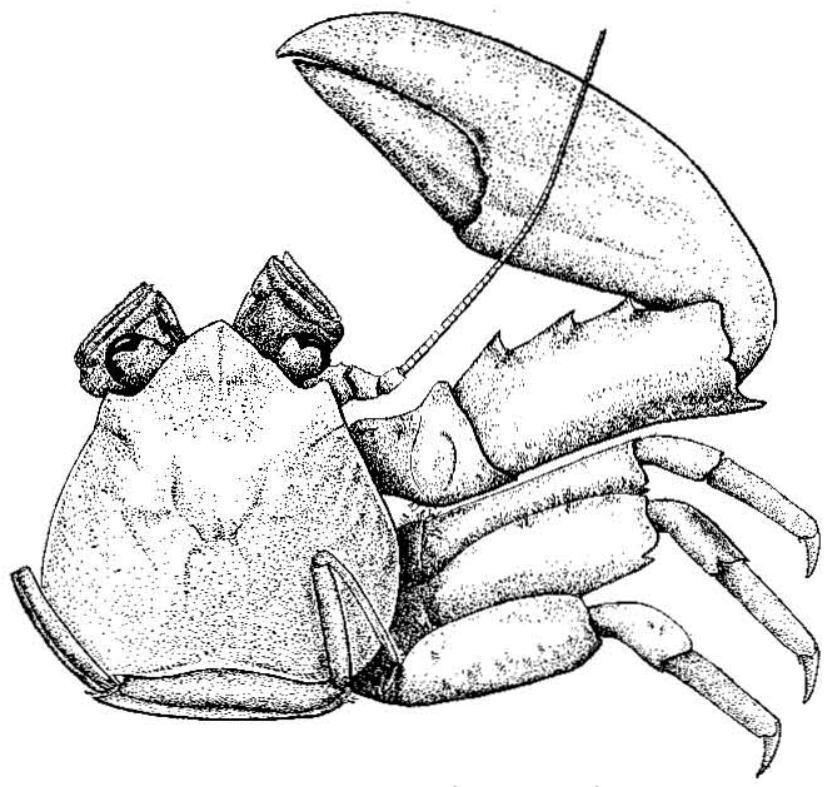

Fig. 5. Petrolisthes hastatus Strmpsnn, male, $\times 4$.

Carapace depressed, a little broader than long, sometimes quite as long as broad; upper surface smooth and marked with faint transverse striae on lateral portions. Front triangular, with apex rounded and concave above; the elevated transverse crest separating front from gastric region almost straight, interrupted in the middle by median frontal furrow. It presents a faint cervical groove towards lateral margins and cardio-branchial groove distinct. There is no epibranchial spine.

First peduncle of antennule broader than long, anterior margin 
divided into three lobes, median lobe much broader, rounded and undulated, lateral lobes narrow, rather acuminate; ventral surface ornamented with a few transverse, undulated striae; lateral margins furnished with long, feather-like hairs. Basal peduncles of antenna cylindrical, smooth; second peduncle furnished with a laminate crest and short setae on anterior margin; upper proximal angle of the crest somewhat acuminate, and upper distal angle rounded; anterior margin of third peduncle more or less granulated. The relative lengths of basal peduncles are II : III : IV $=4: 3: 3$. Merus of third maxilliped longer than broad with acuminate triangular crest which is asymmetrical, its ventral surface ornamented with

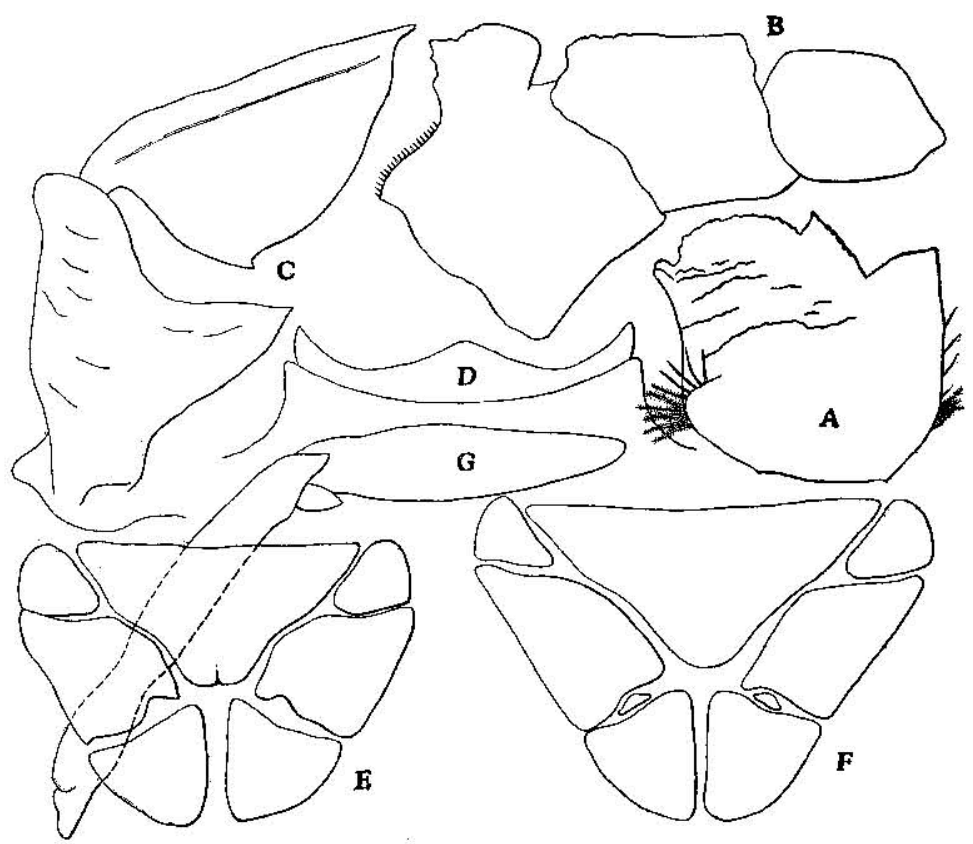

Fig. 6. Petrolisthes hastatus STIMPson.

A First peduncle of right antennule, ventral view, $\times 25, \quad$ B Basal peduncles of right antenna, ventral view, $\times 25, \mathrm{C}$ Carpus and merus of third maxilliped of right side, ventral view, $\times 19, \quad D$ Sternum of third maxilliped, $\times 12$, E Telson of female, $\times 12, \quad F$ Same of male, $\times 12$, G Abdominal appendage of male, $\times 25$.

short, transverse striae; carpus also longer than broad with a deep longitudinal furrow along outer margin; sternum of third maxilliped short and very broad. 
Chelipeds subequal in both sexes; arm provided with a blunt tooth at distal end of anterior margin; wrist slightly shorter than carapace and almost twice as long as broad; the anterior margin armed with three acute teeth; rugose posterior margin at distal end into a rather acute spine; upper surface of wrist covered with flattened granules which gradually pass into small, transverse, squamiform lines in posterior half; palm much depressed, and covered with similar granules and squamiform lines as wrist; inner margin of fingers ornamented with velvety tomentum along whole length and no gap between fingers.

Ambulatory legs sparsely hairy; anterior margins of merus of first three pairs armed with a few (from one to five) spinules; posterior margins of first two pairs armed with an acute spine at subdistal end, those of third pair unarmed; propodus of first three pairs provided with four spinules; two of them at distal end in pair, one before them, and the other at the middle of the segment; dactylus of first three pairs provided with three spinules. Telson of abdomen seven-jointed, median plate rather broad; distal lobe of abdominal appendage of male laminate, with apex rounded.

Colour in life: Dorsal face greenish black, ventral face reddish.

Habitat: Commonly found under rocks between tide-marks.

Material examined:

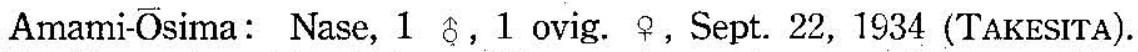
Ryūkyũ: Benoki, Okinawa-Hontō, 1 ô, 2 우 ㅇ, Feb. 9, 1937 (MTYAKE).

Arakawa, Isigaki I., $3 \hat{o} \hat{o}, 4$ 우, Feb. 22, 1937 (MTYAKE).

Maézato, Isigaki I., 8 令 1 , 3 우 우, May 25, 1940 (MrYAKE).

Taiwan: Suō, $1 \hat{\jmath}$, Nov. 4, 1932 (OHshima); 2 ovig. \& $\&$, May 30, 1938 (UTINOM).

Karenkō, 3 호 ô, 2 ㅇ , Mar. 15, 1936 (SAto and SASAKI).

Dimensions (in $\mathrm{mm}$ ):

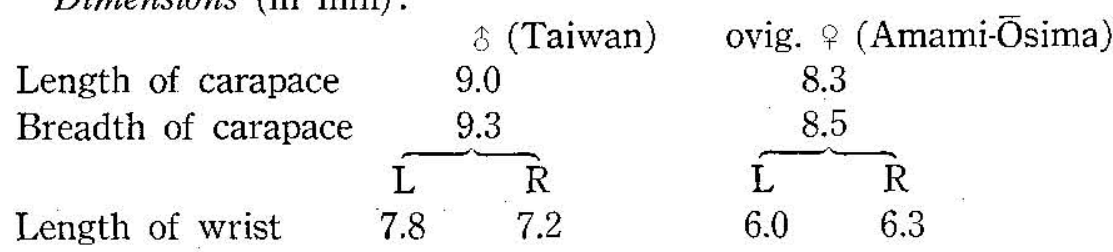




$\begin{array}{lrrrr}\text { Breadth of wrist } & 3.3 & 3.5 & 3.0 & 3.1 \\ \text { Length of palm } & 10.8 & 10.0 & 8.6 & 8.4 \\ \text { Breadth of paim } & 6.9 & 6.5 & 5.5 & 5.3 \\ \text { Length of finger } & 5.7 & 6.0 & 4.5 & 4.4\end{array}$

Distribution: Nicobars, Mergui Is., Sumatra, Java, Bismarck Is., Nippon: Kikai-Zima (northern limit), Amami-Ōsima, Ryūkyū (present paper), Taiwan.

\section{Petrolisthes unilobatus HENDERSON Text-figs. $7-8$.}

Petrolisthes unilobatus Henderson 1888, p. 106, Pl. 11, figs. 3, 3 aOff Nukalofa, Tongatabu Is. (Type-locality).

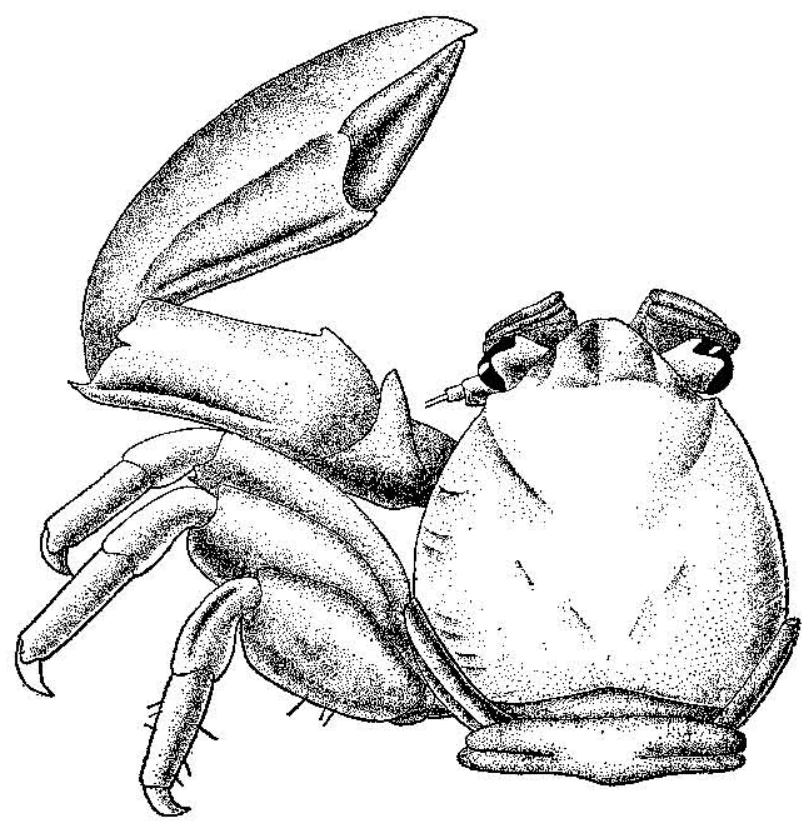

Fig. 7. Petrolisthes unilobatus Henderson, male, $\times 7$.

Carapace in our specimens a little broader than long, but it is said to be slightly longer than broad in HENDERSON's type specimens; upper surface of carapace smooth, polished, areolation as in $P$. japonicus.

First peduncle of antennule broader than long, anterior margin 
furnished with one obtuse tooth on each lateral angle; inner part of anterior margin more or less undulated; outer lateral margin armed with a few teeth, ventral surface ornamented with transverse striae. Antenna almost smooth, without spinule or teeth; first peduncle short, its anterior angle acuminate; second peduncle

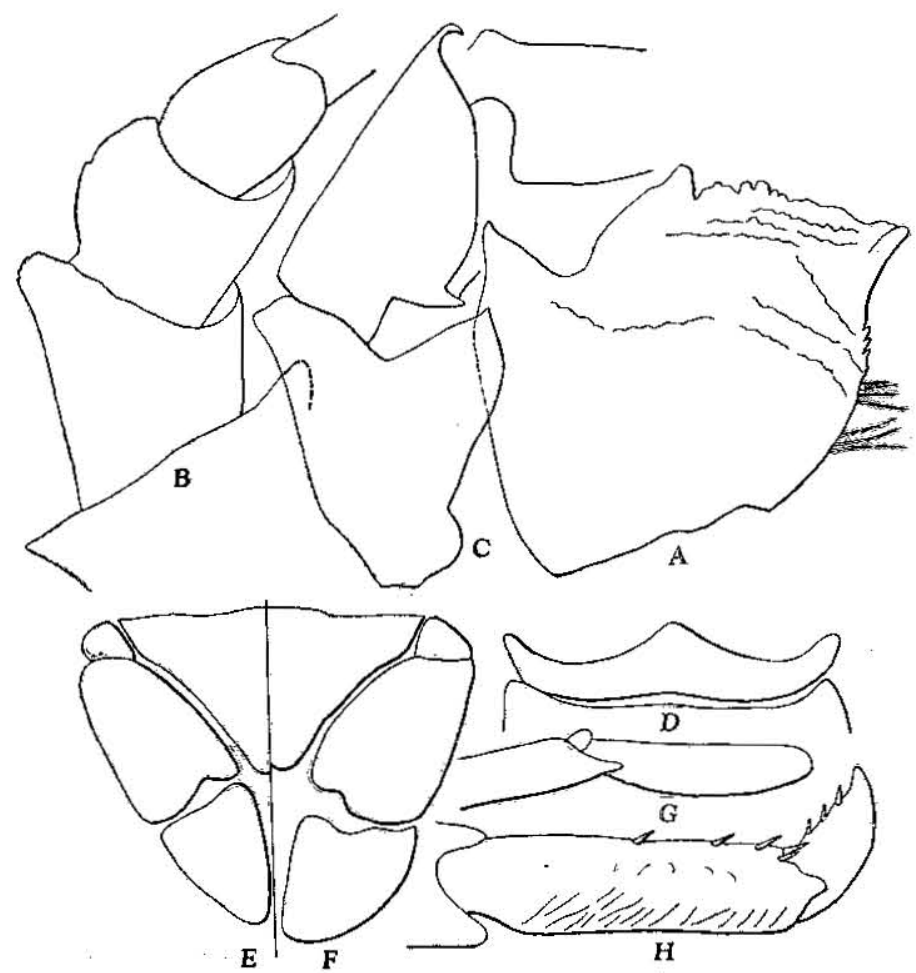

Fig. 8. Petrolisthes unilobatus Henderson.

A First peduncle of left antennule, ventral view, $x 40$, B Basal peduncles of right antenna, ventral view, $\times 40, \mathrm{C}$ Merus and carpus of third maxilliped of right side, ventral view, $\times 25, \quad \mathrm{D}$ Sternum of third maxilliped, $\times 12$, F Telson of male, $\times 12, \quad F$ Same of female, $\times 12, \quad$ G Distal part of abdominal appendage of male, $\times 40, \quad H$ Dactylus and propodus of second ambulatory leg, $\times 12$.

slightly produced on upper distal angle; upper margin of third peduncle much produced as in $P$. japonicus. Relative lengths of basal peduncles are II : III : IV $=1: 1: 1$. Merus of third maxilliped 
longer than broad; the laminate crest of merus rather broad, its upper inner angle acuminate. Anterior and posterior margins of the crest almost parallel to each other in $P$. japonicus, but much divergent proximally in $P$. japonicus; ventral surface ornamentened with transverse striae. Distal or anterior margin of carpus, which articulates with propodus, presents smooth curve in this species, but more or less angular curve in P. japonicus. Ornamentation of ventral surface of carpus as in $P$. japonicus, but short transverse striae occur in this species; sternum of third maxilliped broader than the corresponding part of $P$. japonicus or $P$. inermis; anterior border of sternum presents smooth, rounded curve as in $P$. inermis, but it is straight and angular in $P$. japonicus.

Chelipeds subequal in both sexes; wrist a little shorter than length of carapace, and more than twice as long as broad; the anterior margin armed with only one tooth in proximal part as in $P$. japonicus which is very small, almost rudimentary; the rugose posterior margin prolonged at its distal end into an acute spine as in $P$. hastatus, and unarmed; palm longer than wrist and a little less than twice as long as broad; wrist and palm of female broader than those of male in our collection; inner margins of fingers ornamented with velvety tomentum along whole length as in $P$. hastatus. As to the tomentum of fingers in $P$. japonicus it is complete in larger specimens, but in small specimens ornamented with short hairs very slightly. $P$. inermis ornamented with long hairs thickly on inner margin of fingers.

Ambulatory legs much compressed; merus of first pair armed with a tooth on distal end of posterior margin; unarmed in the two following pairs. P. japonicus armed in the same manner on first two pairs. Merus of the present species broader than that of $P$. japonicus; carpus without spine on upper distal angle in all the specimens of our collection, while $P$. japonicus armed with a spine at least on first pair; propodus provided with five spinules as in $P$. japonicus; dactylus provided with three spinules as in other members of the genus Petrolisthes. Telson of abdomen seven-jointed, in female slightly broader than in male; telson of $P$. japonicus broader than in this species.

Colour in alcohol: Whitish.

Habitat: Found in coral reefs between tide-marks. 
Material examined:

Ryūkyū: Benoki, Okinawa-Hontō, 2 소요, 2 우 우, Feb. 9-10, 1937 (OHShima and Mryake).

Taiwan: Kankau, near Garanbi, 1 ovig. 우, carapace broken, Jun., 1938 (UTINOMI).

Dimensions (in $\mathrm{mm}$ ):

\begin{tabular}{|c|c|c|c|c|c|c|c|c|c|c|}
\hline & & $\hat{o}$ & & & 우 & & & & \multicolumn{2}{|c|}{ ovig. 우 } \\
\hline Length of carapa & & 6.7 & & & 5.3 & & & & .. & \\
\hline Breadth of carapa & & 6.9 & & & 5.4 & & & & $\ldots$ & \\
\hline Breadth of front & & 3.5 & & & 2.7 & & & & & \\
\hline & $\mathrm{L}$ & $\mathrm{R}$ & $\mathrm{L}$ & $\mathrm{R}$ & $\mathrm{L}$ & $\mathrm{R}$ & $\mathrm{L}$ & $\mathrm{R}$ & $\hat{L}$ & $\mathrm{R}$ \\
\hline Length of wrist & $\ldots$ & 5.2 & 4.3 & 4.3 & 3.7 & 4.0 & 3.0 & 3.5 & 4.0 & . \\
\hline Breadth of wrist & $\ldots$ & 2.2 & 1.7 & 1.9 & 1.5 & 1.6 & 1.5 & 1.6 & 1.8 & ․ \\
\hline $\begin{array}{l}\text { Length of wrist } \\
\text { Breadth of wrist }\end{array}$ & $\cdots$ & 2.36 & 2.53 & 2.26 & 2.46 & 2.5 & 2.0 & 2.2 & 2.2 & $\cdots$ \\
\hline Length of palm & $\ldots$ & 7.0 & 5.4 & 6.5 & 5.0 & 5.5 & 4.1 & 4.5 & 5.0 & \\
\hline Breadth of palm & $\ldots$ & 3.9 & 3.0 & 3.6 & 2.8 & 3.0 & 2.5 & 2.7 & 3.0 & $\cdots$ \\
\hline $\begin{array}{l}\text { Length of palm } \\
\text { Breadth of palm }\end{array}$ & $\cdots$ & 1.8 & 1.8 & 1.8 & 1.78 & 1.8 & 1.6 & 1.6 & 1.6 & \\
\hline
\end{tabular}

Meri of left ambulatory legs

Length of first pair

Breadth of first pair

Length of first pair

Breadth of first pair

Length of second pair

Breadth of second pair

Length of second pair

Breadth of second pair

Length of third pair

Breadth of third pair

Length of third pair

Breadth of third pair
3.7

1.6

2.3

4.0

2.45

1.6

3.7

2.3

1.6

3.2

3.0

2.6

3.6

1.4
-1.4

1.4

1.2

1.7

2.1

2.6

2.14

2.1

4.0

3.4

3.0

2.8

2.4

1.7

1.6

1.6

1.6

$\begin{array}{ll}3.7 & 2.7 \\ - & \end{array}$

1.7

1.7

3.1

1.7

2.5

2.4

Distribution: Okinawa-Hontō, Ryūkyū; Taiwan; Tongatabu Is.

\section{Petrolisthes indicus DE MAN}

Text-figs. 9-10.

Petrolisthes indicus DE MAN 1893, p. 293, Pl. 7, figs. 3, 3a-Endeh, Flores (Type-locality). 
Petrolisthes securiger Melin 1939, p. 109, text-figs. 67-68-Ogasawara Is.

Carapace broader than long in female, a little convex in both directions, uneven on upper surface. Lateral margin of carapace cristatc, slightly divergent posteriorly. Front deflexed downwards, with three lobes, median lobe much deflexed, lateral lobes not so deflexed and separated by a deep sinus. Gastric region most elevated, subregions distinct; cervical groove deep; cardiac region slightly elevated; branchial regions covered with numerous granules or lobules above, without epibranchial spine.

First peduncle of antennule broader than long; anterior margin undulated, without tooth or spine; ventral surface covered with three transverse, undulated lines which are provided with microscopical hairs anteriorly; outer and inner angles of anterior margin furnished with a few feather-like hairs. First peduncle of antenna small, short, and provided with rounded obtuse process at the upper

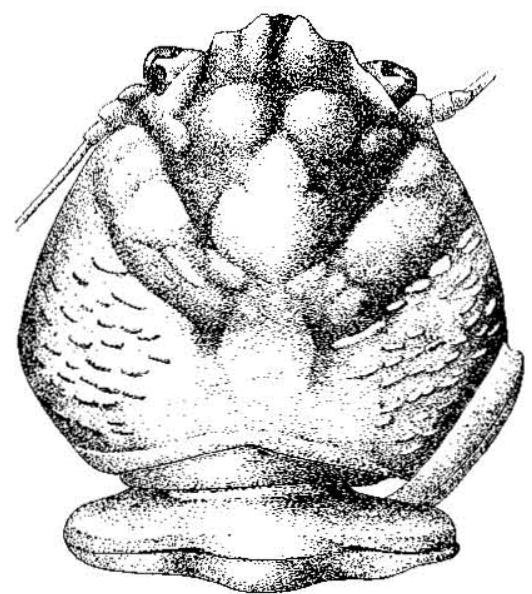

Fig. 9. Petrolisthes indicus de Max, Dorsal face of carapace of ovigerous female, $\times 12$. extremity, with apex more or less undulated; second peduncle provided with rather broad protuberance on anterior margin; anterior margin of third peduncle presents somewhat convexed curve; fourth peduncle cylindrical. Relative lengths of basal peduncles of antenna are II : III $: I V=6: 5: 5$. Merus of third maxilliped longer than broad, ornamented with short, transverse striae on ventral surface; the crest of merus rounded; carpus ornamented with granules on ventral surface, with the inner margin slightly rounded, smooth anteriorly.

Chelipeds subequal in both sexes; wrist shorter than carapace and more than twice as long as broad; edge of its anterior margin entire, and unarmed excepting proximal tooth which is small and 
stout as in $P$. japonicus or $P$. inermis; posterior margin prolonged at its distal end into a rather acute spine as in $P$. hastatus; the upper surface furnished with three longitudinal grooves and covered with short, transverse, squamiform lines; palm longer than broad and covered with similar squamiform lines on upper surface as in wrist; the inner margin prolonged at the distal end into a small tooth; the ventral surface smooth and ornamented with a longitudinal line of velvety tomentum at outer margin; fingers shorter than palm, ornamented with a similar tomentum along the cutting margins and no gap left between them.

Ambulatory legs sparsely hairy; merus trigonal, furnished with two longitudinal grooves on dorsal surface, and covered with fine granules in anterior half which pass into short, transverse, squamiform lines in posterior half; outer margin of carpus provided with a longitudinal crest along the whole length; propodus trigonal, its

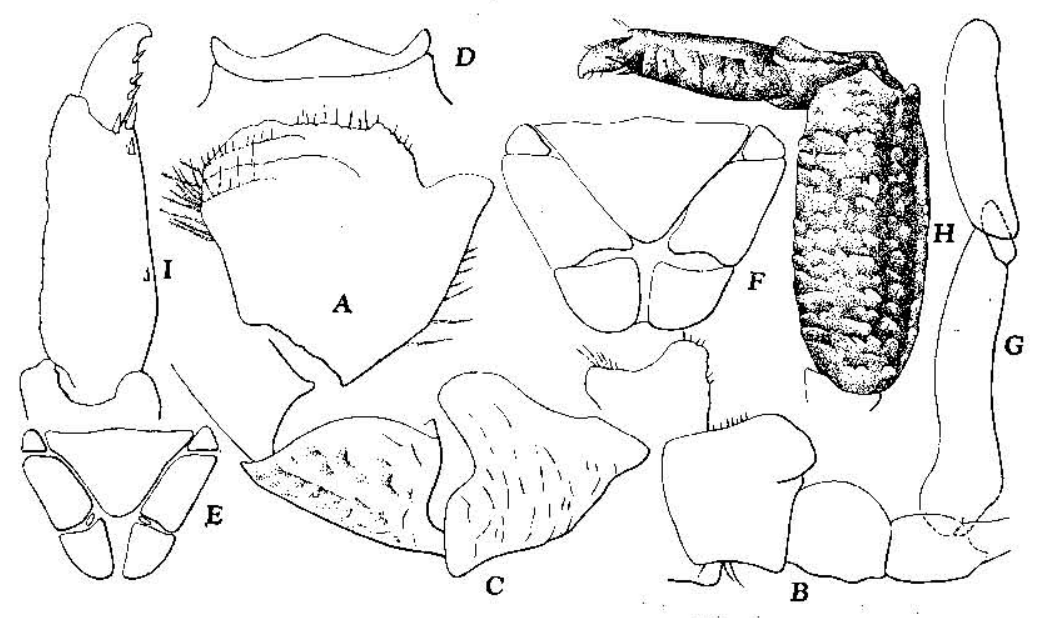

Fig. 10. Petrolisthes indicus DE MAN.

A First peduncle of right antennule, ventral view, $\times 32, \quad$ B Basal peduncles of right antenna, ventral view, $\times 32, \mathrm{C}$ Merus and carpus of third maxilliped of right side, ventral view, $\times 20, \quad$ D Sternum of third maxilliped, $\times 9.6$, E Telson of male, $\times 9.6, \quad F$ Same of female, $\times 9.6, \quad$ G Abdominal appendage of male, $\times 32, \quad H$ Left second ambulatory leg, dorsal view, $\times 9.6$.

dorsal surface ornamented with short, transverse striae, posterior margin armed with four spinules, of which two at distal end in pair, a little anteriorly occurs another spinule, while the remaining 
one stands at one-third from the proximal end of the segment; Melin described only one spinule at distal end of propodus, distal portion of propodus somewhat hairy; dactylus provided with three spinules along the posterior margin. Telson of abdomen sevenjointed; the distal lobe of abdominal appendage of male spatulashaped, with apex rounded as in P. japonicus.

Colour in alcohol: Whitish.

Habitat: Found under rocks between tide-marks.

Material examined:

Suō, Taiwan, $1 \hat{\jmath}, 1$ ovig. 우, May 30, 1938 (UTinomi).

Kankau, N. E. of Garanbi, Taiwan; 1 ovig. ㅇ, Jun. 15, 1938 (UTINOMI).

Dimensions (in $\mathrm{mm}$ ):

Length of carapace

ovig. \&

5.2

Breadth of carapace

Length of wrist

Breadth of wrist

Length of palm

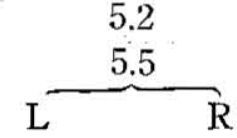

Breadth of palm

3.5

3.3

1.5

1.5

4.8

4.3

3.5

3.3

3.1

2.6

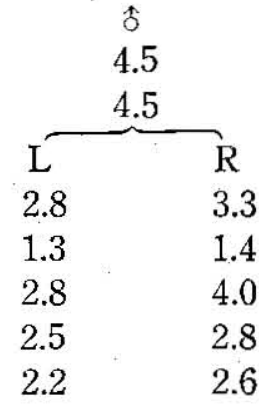

Distribution: Flores, Ogasawara Is., Taiwan (present paper). Remarks: The collection contains another ovigerous female from Kankau, Taiwan, with carapace detached. I refer it to this species by reason of the other important structures, but the following characters differ from the above description. Antero-outer angle of first peduncle of antennule more or less angular; second peduncle of antenna cylindrical, with a small protuberance at the antero-distal end; antero-inner angle of merus of third maxilliped pointed, not rounded; ventral surface of palm of cheliped smooth, without velvety tomentum.

6. Petrolisthes japonicus (DE HAAN)

Text-figs. 11-13.

Porcellana japonica DE HAAN 1849, p. 199, P1. 50, fig. 5--Nippon (Type-locality). 
Porcellana (Petrolisthes) japonica DE MAN 1888a, p. 255-Elphinstone Island Bay, Mergui Is.

Petrolisthes japonicus STIMPSON 1858, p. 214 ; 1907, p. 184-Simoda; Kikai-Zima ; Amakirrima Is. (=Kerama Is.); Ogasawara Is. ; Hongkong.

ORTMANN 1892, p. 261-Kadsiyama (=Katuyama, Sagami Bay); Kagosima; Amami-Ōsima.

\section{Malacca.}

DE MAN 1896, p. 373-West coast of Borneo;

.......... BALSS 1913, p. 30--Hukuura; Katuyama; Nagasaki; Ogasawara Is.

KiкUсHI 1932, p. 7-Toyama Bay.

MiYAKE 1937 d, p. 210, Pl. 12, fig. 5-Tanabe Bay.

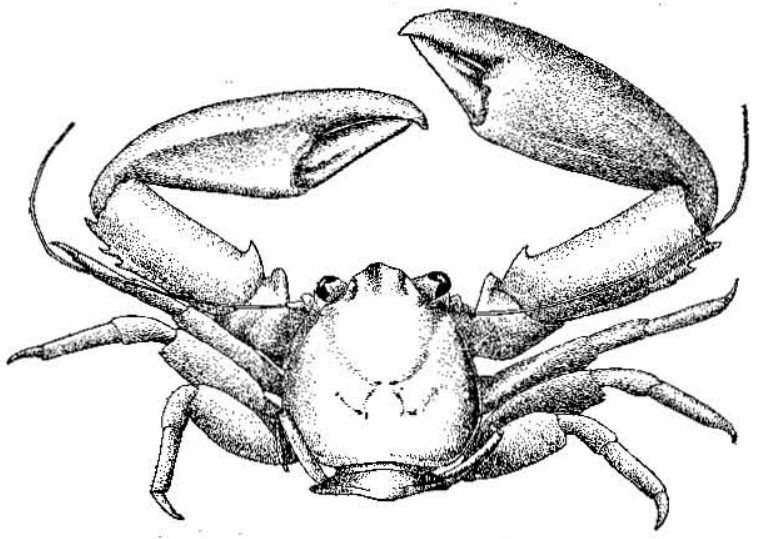

Fig. 11. Petrolisthes japonicus (Dr. HAsN), male, $\times 3$.

Carapace depressed, a little longer than broad, upper surface smooth, furnished with delicate transverse striae on lateral portions in larger specimens. Front triangular, with apex rounded and concave above. There is no transverse crest to separate front from gastric region. Neither is there any epibranchial spine. Lateral margins of carapace more or less divergent posteriorly. Epimera ornamented with a few longitudinal grooves. Cervical groove more or less distinct.

First peduncle of antennule a little broader than long, its anterior margin provided with three spines, two of them on inner 
ancle rather acuminate, the remaining one on the outer angle, and more or less obtuse; ventral surface ornamented with a few transverse striae in anterior half; first peduncle of antenna very short, and inner distal angle projecting into an acuminate tooth; second peduncle broader than long, anterior margin prolonged at distal end into a rather acute spine, third peduncle much produced at the middle of anterior margin; fourth peduncle cylindrical, smooth. The relative lengths of basal peduncles of antenna are II : III : IV $=9: 9: 11$. Merus of third maxilliped longer than broad, with quadrate crest; ventral surface of merus ornamented with transverse striae; carpus ornamented with longitudinal striae. Anterolateral margin of sternum of third maxilliped straight and their lateral process oblong with apex rounded.

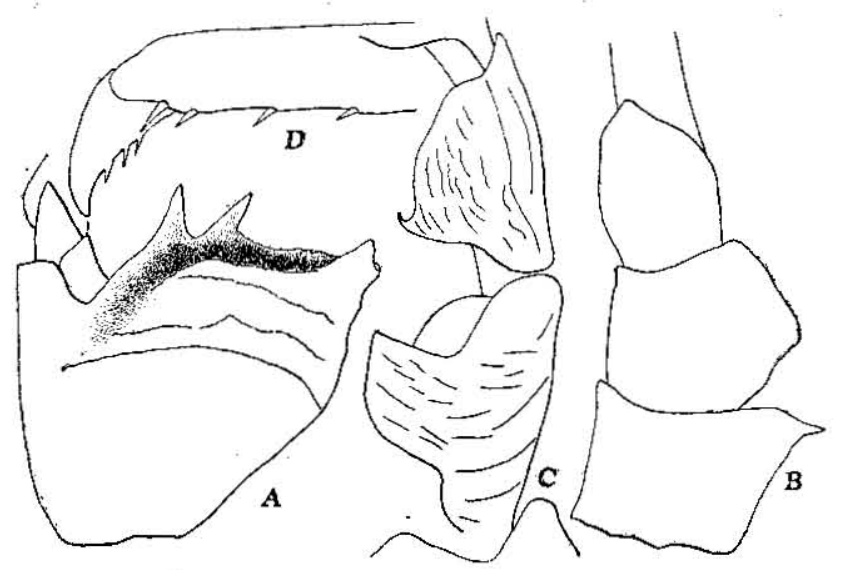

Fig. 12. Petrolisthes japonicus (DE HAAN).

A First peduncle of left antennule, ventral view, $\times 25$,

B Basal peduncles of right antenna, ventral view, $\times 25$,

C Merus and carpus of third maxilliped of left side, ventral view, $\times 12$, D Distal part of ambulatory leg, $\times 12$.

Chelipeds unequal, smooth, glabrous; arm provided with a blunt tooth at distal end of anterior margin; wrist of larger cheliped nearly as long. as the length of carapace and more than twice as long as broad, upper surface of wrist covered with fine granules sparsely in anterior half, which gradually pass into small squamiform lines in posterior half, and the anterior margin armed 
with an acuminate spine at proximal end, but sometimes two spines, as a second small spine occurs before the middle of the segment; the rugose posterior margin armed with two to four spines, the distal one of them largest; upper surface of palm rather convex and covered with fine granules; fingers very short, immovable finger a little longer than movable one; inner margins of both fingers without hairs, smooth; there is no gap between them.

Ambulatory legs sparsely hairy; merus of first two pairs armed with a small tooth at distal end of posterior margin, that of third pair unarmed; carpus of first pair armed with an acute spine at distal end of anterior margin, but unarmed in two follow-

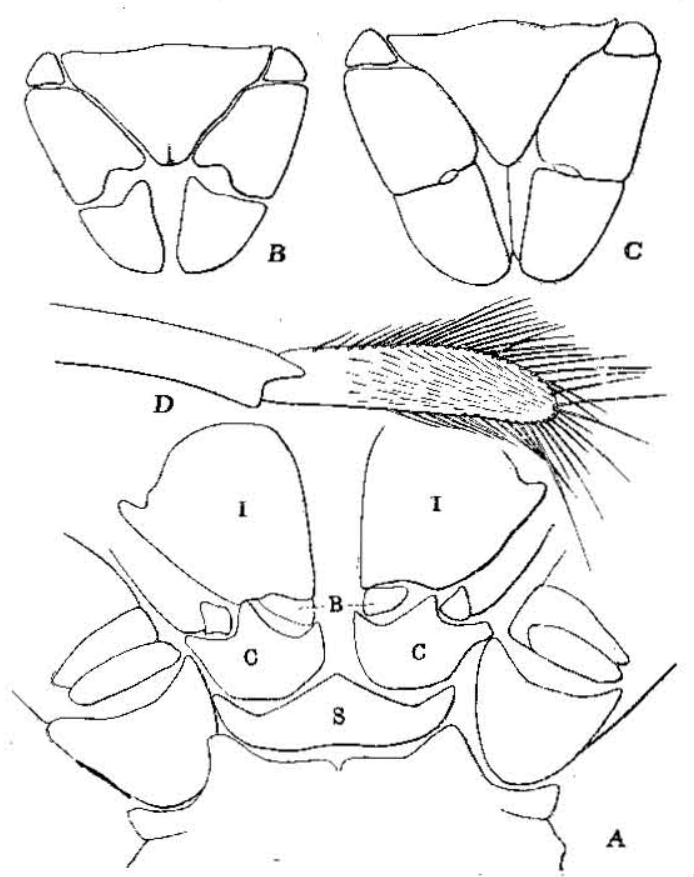

Fig. 13. Petrolisthes japonicus (DE HAAN).

A Basal segments of third maxilliped (S- sternum of third maxilliped, C- coxa, B- basis, I- ischium), $\times 7.5, \quad B$ Telson of male, $\times 7.5, \quad C$ Same of ovigerous female, $\times 7.5, \quad$ D Distal part of abdominal appendage, $\times 25$.

ing pairs; propodus of first three pairs as a rule armed with five spinules on postrior margin, usually three of them along the longi- 
tudinal axis, but sometimes two or four spinules occur in their place on the axis, and remaining two spinules at distal end in pair; dactylus of first three pairs armed with three spinules on posterior margin. Telson or last segment of abdomen seven-jointed, rather narrow in both sexes; distal lobe of abdominal appendage of male spatulashaped, with apex rounded. brown.

Colour in life: Dorsal face greenish black, ventral face reddish

Habitat : Commonly found under rocks between tide-marks.

Material examined:

Kominato, 5 of $\{$, July 1937 (KuBo).

Simoda, 1 s, March 1940 (Murakami).

Hatake-zima, Prov. Kii, $1 \hat{\delta}, 2$ q $q$, in the Seto Marine Biological Laboratory, Jul. 7, 1922.

Sami, Okayama-ken, Inland Sea, 10 令, 8 우, Aug. 9, 1933 (MIYAKE).

Okinosima I., Hukuoka-ken, $2 \hat{\delta} \hat{o}, 1$ ? , May 19-29, 1933 (Ohshima, Ikeda and Yasumoto).

Hakata Bay, Hukuoka-ken, 5 송 ㅇ, 3 우 우, July 10, 1934 (Mryake).

Tomioka, Amakusa, Many specimens, May 8, 1940 (MrYAKe).

Ōsima Islet, off Akune, Kagosima-ken, 2 ô $\delta$, Sep. 10, 1934 (MiYAKE). Taniyama, Kagosima-ken, $1 \frac{d}{b}$, in the Kagosima Second Middle School, May, 1912 (URITA).

Okiko-zima, Kagosima Bay, $3 \hat{s} \hat{o}$, in the Kagosima College of Agriculture and Forestry.

Benoki, Okinawa-Hontō, Ryūkyū, 2 oิ ô, 2 우 우, Feb. 9-10, 1937 (OHSHIMA and MIXAKE).

Miyako I., Ryūkyū, $1 \hat{o}$, in the Miyako Middle School (NAKASONE).

Dimensions (in $\mathrm{mm}$ ):

\begin{tabular}{|c|c|c|c|c|}
\hline & 6 (Kominato) & f (Hakata Bay) & \multicolumn{2}{|c|}{ (Okinosima) } \\
\hline Length of carapace & 9.0 & 9.0 & & \\
\hline Breadth of carapace & 8.5 & 8.5 & & \\
\hline Breadth of front & 4.0 & 4.0 & & \\
\hline & $\mathrm{R}$ & $\mathrm{R}$ & $\mathrm{L}$ & $\mathrm{R}$ \\
\hline Length of wrist & 8.5 & 9.0 & 6.5 & 9.3 \\
\hline Breadth of wrist & 3.5 & 3.5 & 2.5 & 2.4 \\
\hline
\end{tabular}


Length of wrist

Breadth of wrist

$2.4 \quad 2.6$

$2.4 \quad 2.3$

2.6

2.4

Length of palm

$11.3 \quad 10.0$

$12.0 \quad 10.8$

$8.0 \quad 10.5$

Breadth of palm

$6.0 \quad 5.0$

$6.2 \quad 5.5$

$4.0 \quad 5.2$

Length of palm

Breadth of palm

$1.9 \div 2.0$

$1.93 \quad 1.96$

$2.0 \quad 2.0$

Meri of ambulatory legs

Length of first pair

5.4

2.0

2.7

5.0

2.5

2.0

4.0

2.5

1.6

Length of third pair

Breadth of third pair
5.4

2.0

2.7

5.3

2.5

2.1

4.3

2.5
5.3

1.8

2.9

5.0

2.4

2.0

4.5

2.2

2.0

Distribution: Mergui Is.; Malacca; Borneo; Nippon: Toyama Bay (northern limit on continental side); Okinosima, Hukuokaken; Hakata Bay; Nagasaki; Amakusa; Kagosima-ken; Inland Sea; Kominato (northern limit on pacific side); Sagami Bay; Simoda; Tanabe Bay; Kagosima; Amami-Ōsima; Ryūkyū ; Hongkong; Ogasawara Is.

\section{6'. Petrolisthes elongatus (H. MILNE-EDwARDS) \\ Text-figs. 14-15.}

Porcellana elongata H. MiLne-EDWARds 1837, p. 251-New Zealand (Type-locality).

.............. Miers, Zool. "Erebus and Terror," Crust., 1874, p. 3, Pl. 3, fig. 3-New Zealand.

........ ....... Miers, Cat. Crust. N. Z., 1876, p. 60-New Zealand.

This species is closely allied to $P$. japonicus, and inhabits only the Sea of New Zealand. I received one male specimen of New Zealand from Mr. WARD of the Australian Museum. 
Petrolisthes elongatus attains a large size, having rather broad chelipeds and ambulatory legs, and ornamentation of carapace and legs more distinct than those of Petrolisthes japonicus. It is easily distinguished by the following characters.

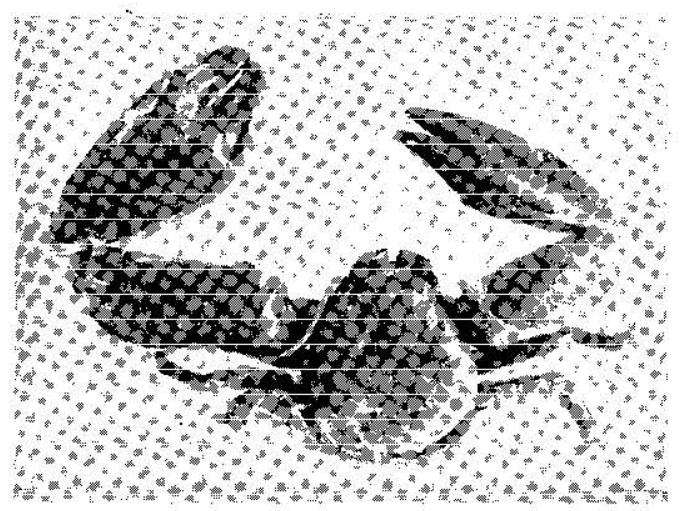

Fig. 14. Petrolisthes elongntus ( $\mathrm{H}$. Mrtone-Finwarts), maie, from New Zealand, natural size.

1) Front of $P$. elongatus is broader than that of $P$. japonicus. 2) Anterior teeth of the first peduncle of antennule are broader and shorter than those of the latter, and transverse striae of ventral surface are numerous in this species. 3) The laminate crest of third maxilliped is broader, and upper angle rounded in this species, but it is narrower, with acuminate upper angle. 4) Sternum of third maxilliped with a median groove distinct in this species, while such a groove is absent in $P$. japonicus. 5) The anterior tooth of wrist is broad, obtuse or rudimentary in this species, but it is narrow and acuminate in $P$. elongatus. 6) The rugose posterior margin of wrist armed with three spines on both sides, while in $P$. japonicus, there are two to four. 7) The tubercle of movable finger of the longer cheliped is prominent, but it is faint in $P$. japonicus. 8) The spines of merus and carpus are well developed, while they are not so distinct, sometimes even rudimentary in $P$. japonicus. 10) Propodus and carpus furnished with thick setae, but those of $P$. japonicus with sparse hairs.

Material examined: Porto Beloo, near Dunedin, South Island of New Zealand, 1 ô (sent by Mr. WARD). 


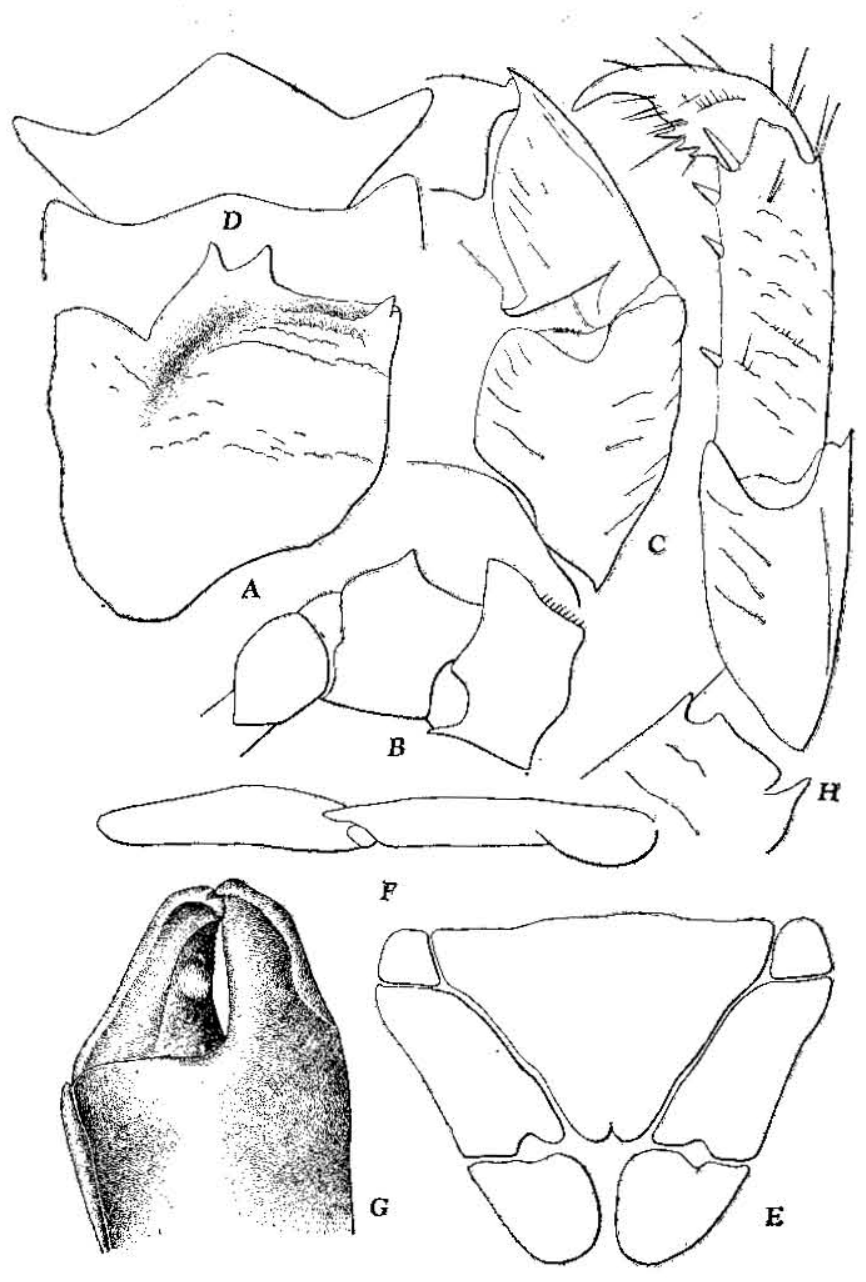

Fig. 15. Petrolisthes elongatus (H. MiLne-Edwaris).

A First peduncle of left antennule, ventral view, $\times 12$,

B Basal peduncles of left antenna, dorsal view, $\times 12$,

$\mathrm{C}$ Merus and carpus of third maxilliped, $\times 7.5, \mathrm{E}$ Telson of male, $\times 7.5, \quad F$ Abdominal appendage of male, $\times 12$, $\mathrm{G}$ Finger of larger chela $\times 2.5 \mathrm{H}$ Second ambulatory leg of left side, dorsal view, $\times 7.5$.

Dimensions (in $\mathrm{mm}$ ):

Length of carapace 
Length of wrist

Breadth of wrist

Length of wrist

Breadth of wrist

Length of palm

Breadth of palm

Length of palm
Breadth of front

Breadth of palm

$\begin{array}{rr}19.0 & \\ 19.0 & 7.8 \\ 9.5 & 2.4 \\ 2.0 & 17.4 \\ 21.0 & 10.8 \\ 14.0 & 1.5 \\ 1.5 & \end{array}$

Meri of ambulatory legs

Length of first pair

Breadth of first pair

4.3

Length of first pair

Breadth of first pair

2.1

Length of second pair

9.0

Breadth of second pair

5.0

Length of second pair

Breadth of second pair

1.8

Length of third pair

7.0

5.0

Length of third pair

1.4

Breadth of third pair

\section{Petrolisthes inermis HASWELL} Text-figs. 16-17.

Petrolisthes inermis HASWELL 1882, p. 142--Port Denison, Queensland (Type-locality).

Petrolisthes japonicus var. inermis MIERS 1884, p. 268-North Australia.

...................... Grant et MAC Culloch 1906, p. 38North Australia.

Petrolisthes teres MeLin 1939, p. 104, text-figs. 65-66--Ogasawara Is. not Porcellana inermis HeLler 1865 (=Petrolisthes hastatus STIMPSON).

Carapace smooth, a little longer than broad in both sexes. Front slightly broader than that of $P$. japonicus, maximum breadth of front quite as half of maximum breadth of carapace in this species, but it is a little shorter than half of maximum breadth 
of carapace in $P$. japonicus. Lateral margins of carapace slightly rounded, but not so divergent as in P. japonicus. Epimera and subbranchial regions ornamented with downy hairs thickly, but none in P. japonicus.

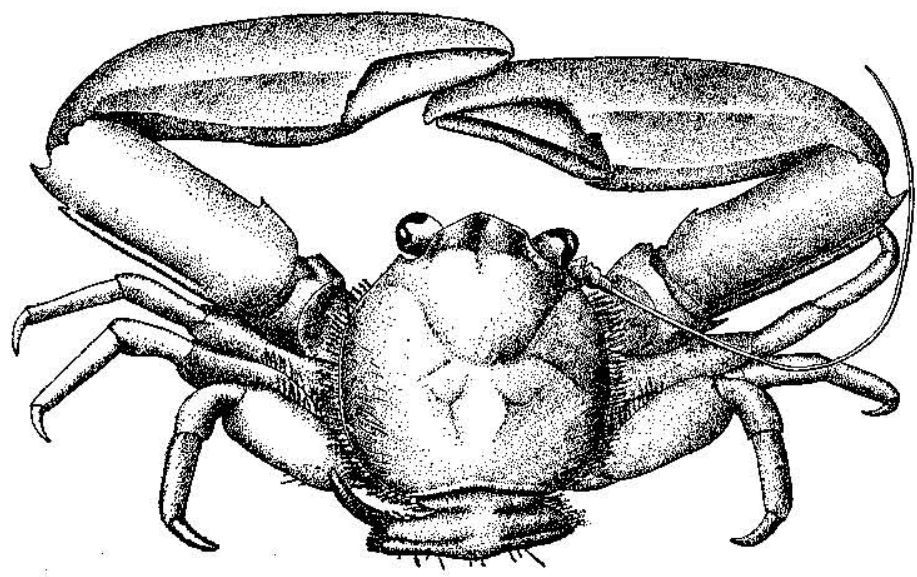

Fig. 16. Petrolisthes inermis HASwEL, male from Queensland, $\times 3.25$.

First peduncle of antennule furnished with three teeth on anterior margin, two of which on inner side much broader than the outer one, sometimes subdivided into small teeth. Third peduncle of antenna armed with one spinule instead of protuberance as present in $P$. japonicus. The relative lengths of basal peduncles of antenna are II $:$ III $:$ IV $=3: 3: 4$. Third maxilliped: Anterolateral angle of the crest of merus rounded. Anterior margin of sternum rounded; the lateral processes triangular with apex pointed.

Chelipeds subequal, smooth; arm provided with a blunt tooth at distal end of anterior margin, and in addition to it a minute tooth attached; wrist of larger cheliped nearly as long as length of carapace and more than twice as long as broad, as in P. japonicus the spine of proximal end on anterior margin of wrist rather smaller than that of $P$. japonicus; rugose posterior margin armed with only two spines in all specimens of our collection; upper surface of wrist smooth, polished, covered with a granulated longitudinal line at the middle of the segment; upper surface of palm smooth, glabrous; inner margin of palm sharply cristate; 
inner margin of fingers ornamented with feather-like hairs along the whole length.

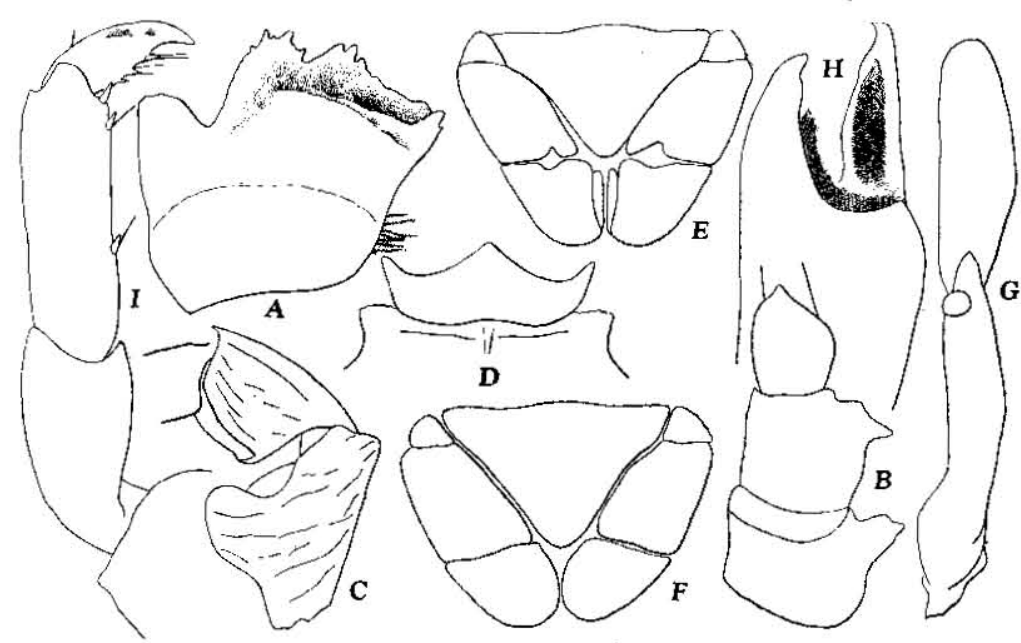

Fig. 17. Petrolisthes inermis Haswell.

A First penduncle of left antennule, ventral view, $\times 20, \quad$ B Basal peduncles of left antenna, dorsal view, $\times 20, \quad \mathrm{C}$ Merus and carpus of third maxilliped of left side, ventral view, $\times 10, \mathrm{D}$ Sternum of third maxilliped, $\times 10$, E Telson of male, $\times 6, \quad F$ Same of ovigerous female, $\times 6, \quad \mathrm{G}$ Abdominal appendage of male, $\times 20, \quad \mathrm{H}$ Fingers of chela, ventral view, $\times 4$, I Second ambulatory leg of right side, dorsal view, $\times 10$.

Ambulatory legs sparsely hairy; upper distal edge of carpus and merus unarmed; anterior margin of merus furnished with feather-like hairs thickly at the proximal parts; distal end of posterior margin of first two pairs angular, toothless; that of third pair rounded; propodus of first pair armed with five spinules on posterior margin: two at distal end in pair, the other two along the longitudinal axis; propodus of second and third pairs armed with four spinules: two at distal end in pair, the other two along the longitudinal axis; dactylus usually armed with three spinules, but sometimes with two or four. Telson of abdomen broader than that of P. japonicus.

Colour in alcohol: Dorsal face orange, ventral whitish.

Habitat: Commonly found under stones between tide-marks. 
Material examined: $2 \hat{\circ} \hat{\circ}, 1$ ovig. 우, Sandgate, Morton Bay, Queensland, Nov. 1937 (sent by Mr. WARD).

Dimensions (in $\mathrm{mm}$ ):

\begin{tabular}{|c|c|c|c|c|c|c|}
\hline & \multicolumn{2}{|c|}{$\jmath$} & \multicolumn{2}{|c|}{$\delta$} & \multicolumn{2}{|c|}{ ovig. 우 } \\
\hline Length of carapace & \multicolumn{2}{|c|}{8.5} & \multicolumn{2}{|c|}{8.0} & \multicolumn{2}{|c|}{8.5} \\
\hline Breadth of carapace & \multicolumn{2}{|c|}{8.3} & \multicolumn{2}{|c|}{7.8} & \multicolumn{2}{|c|}{8.5} \\
\hline Breadth of front & \multicolumn{2}{|c|}{4.5} & \multicolumn{2}{|c|}{4.2} & \multicolumn{2}{|c|}{4.0} \\
\hline & $\mathrm{L}$ & $\mathrm{R}$ & $\widetilde{L}$ & $\mathrm{R}$ & $\overline{\mathrm{L}}$ & $\mathrm{R}$ \\
\hline Length of wrist & 8.0 & 8.2 & 6.6 & 6.8 & 6.5 & 6.5 \\
\hline Breadth of wrist & 3.5 & 3.3 & 2.7 & 2.5 & 2.8 & 2.7 \\
\hline$\frac{\text { Length of wrist }}{\text { Breadth of wrist }}$ & 2.28 & 2.48 & 2.40 & 2.72 & 2.32 & 2.40 \\
\hline Length of palm & 11.0 & 10.8 & 8.5 & 8.0 & 8.0 & 9.0 \\
\hline Breadth of palm & 5.0 & 5.4 & 4.0 & 4.0 & 4.0 & 4.5 \\
\hline$\frac{\text { Length of palm }}{\text { Breadth of palm }}$ & 2.2 & 2.2 & 2.1 & 2.0 & 2.0 & 2.0 \\
\hline
\end{tabular}

Meri of left ambulatory legs

Length of first pair

4.6

4.5

Breadth of first pair

2.0

1.7

1.8

Length of first pair

Breadth of first pair

2.3

2.6

2.5

Length of second pair

4.6

4.5

4.6

Breadth of second pair

2.4

2.0

2.1

Length of second pair

Breadth of second pair

1.9

2.2

2.2

Length of third pair

4.2

4.0

4.2

Breadth of third pair

2.2

2.0

2.2

Length of third pair

Breadth of third pair

1.9

2.0

1.9

Distribution: Ogasawara Islands (northern limit); North East Australia.

\section{Petrolisthes penicillatus (HELLER) \\ Text-fig. 18.}

Porcellana penicillata Heller 1865, p. 79-Nicobars (Type-lacality).

Petrolisthes penicillatus ORTMANN 1897, p. 288-No new locality.

................ Mryake 1942, p. 347, text-figs. 11-12-Micronesia. 
Porcellana villosa Richters 1880 , p. 180, Pl. 17, figs. 11-12-Mauritius.

Petrolisthes villosus OrTwann 1892, p. 264-Fiii Is.

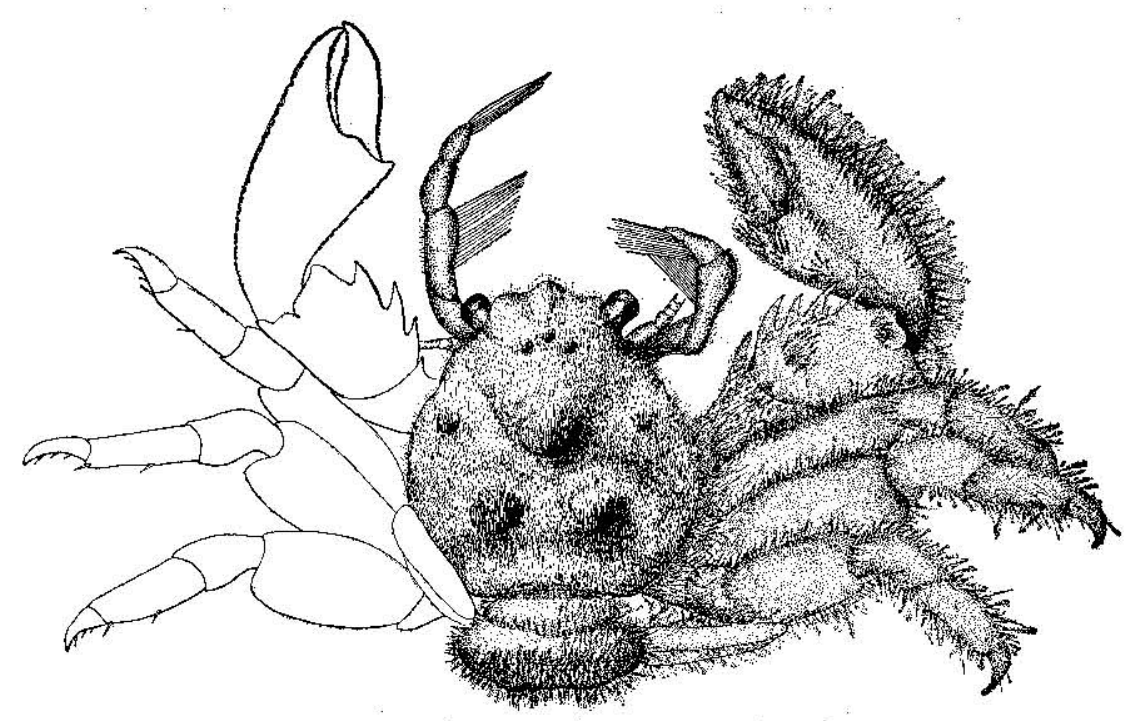

Fig. 18. Petrolisthes penicillatus (HF.LLFR),

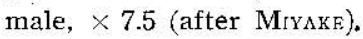

Material examined:

Ryūkyū: Isigaki I., $2 \hat{\jmath} \hat{0}, 4$ 우 우, May 17, 1937 (SenaHA).

Palau Is., $4 \hat{\delta} \hat{\delta}, 1$ q , 4 ovig. 우 우 (reported in my previous paper, 1942).

Dimensions (in $\mathrm{mm}$ ):

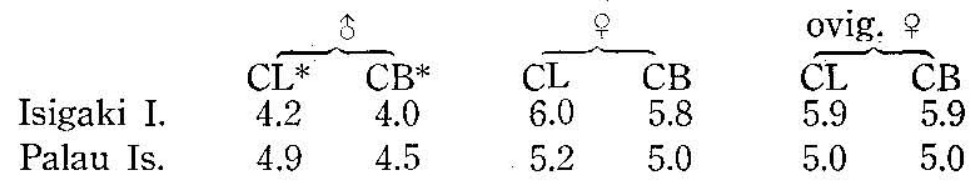

Distribution: Mauritius, Nicobars, Amirante Is., Fiji Is., Palau Is., Isigaki I., Ryūkyü (present paper).

\footnotetext{
* By these abbreviations are meant: CL. length of carapace; CB. breadth of carapace.
} 


\section{Petrolisthes tomentosus (DANA) \\ Text-fig. 19-21.}

Porcellana tomentosa DANA 1852 , p. $420 ; 1855$, Pl. 26, fig. $10-$

Raraka I., Paumotu Is. (Type-locality).

Petrolisthes tomentosus ORTMANn 1892, p. 264-South Sea.

....... ........ ORTMANN 1897, p. 288-Name only.

Petrolisthes pubescens STIMPSON 1858, p. 241; 1907, p. 183, P1. 22, fig. 3-Foukow Bay $(=$ Nase Bay), Amami-Ōsima.

not Petrolisthes pubescens Balss 1913, p. 30, Pl. 1, fig. 2 [Syn. Petrolisthes coccineus (OWEN)].

Petrolisthes carinipes MeLIN 1939, p. 97, text-figs. 62-64-Ogasawara

Is.

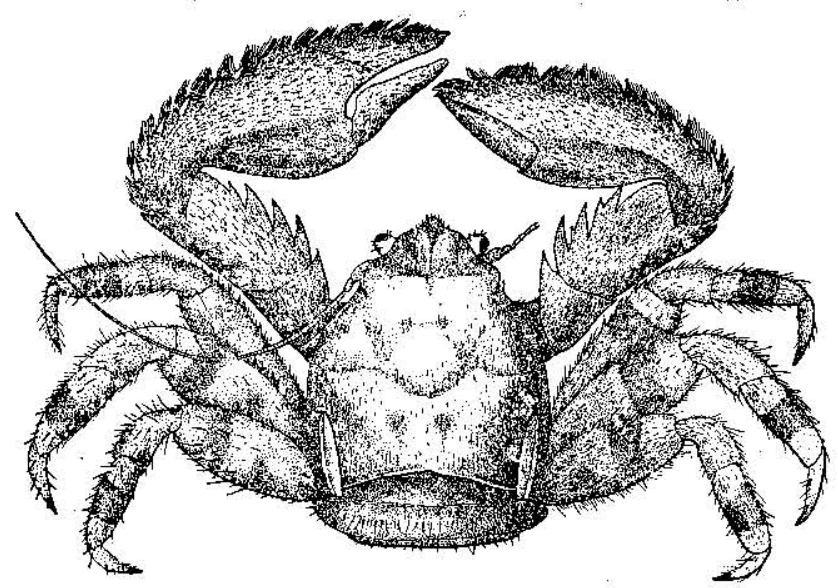

Fig. 19. Petrolisthes tomentosus (DANA), male, $\times 4$.

Carapace depressed, a little longer than broad. Carapace and legs all over pubescent above; upper surface almost smooth beneath pubescence, regional grooves rather distinct; lateral margins more or less rounded, posterior margin strongly curved forwards. Supraorbital spine absent in this species. A small epibranchial spine sharply produced.

First peduncle of antennule a little longer than broad, anterior margin hairy and denticulated, provided with five teeth, both lateral teeth larger than the median three; ventral surface ornamented with about four transverse, undulated striae; lateral margin orna- 
mented with a tuft of feather-like hair posteriorly on both sides. Basal peduncles of antenna ornamented with long hairs sparsely; the laminate crest of second peduncle much produced with apex undulated; dorsal surface of the crest ornamented with a few hairs; between second and third peduncles one stout, rather larger tubercle projects posteriorly; anterior margin of third peduncle very slightly rounded, ornamented with a few long hairs; fourth peduncle furnished with a tuft of hair on both distal and proximal ends. Outer distal angle of ischium of third maxilliped not produced; merus ornamented with short, transverse striae on ventral surface; its crest very narrow and much produced inwards with apex sharply pointed; anterior margin of the crest more or less undulated distally; carpus rather slender, furnished above with thick setae. Sternum of third maxilliped much broader, almost equal to the breadth of anterior margin of thoracic sternum.

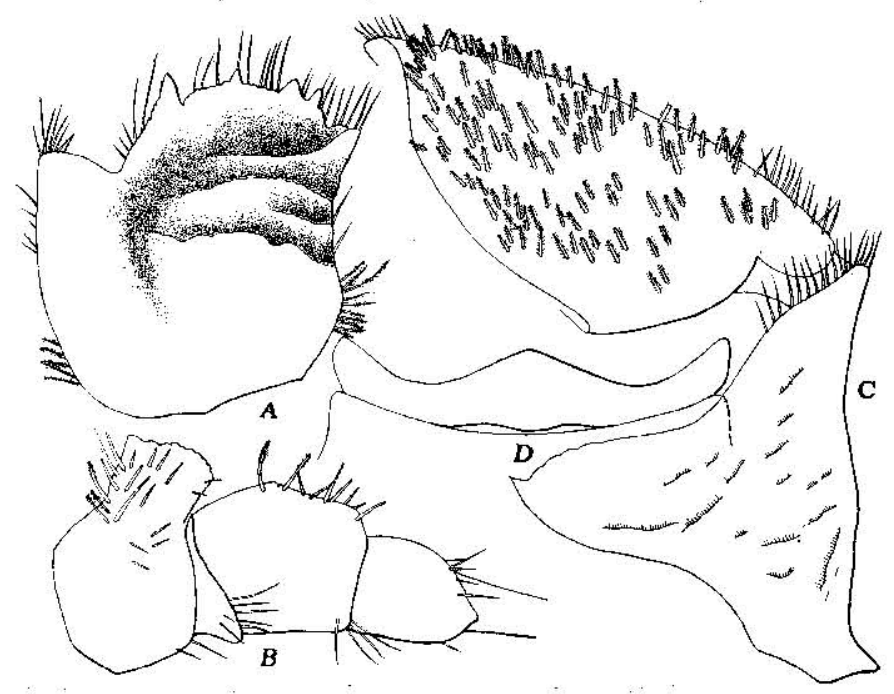

Fig. 20. Petrolisthes tomentosus (Dana).

A First peduncle of left antennule, ventral view, $\times 25, \quad$ B Basal peduncles of right antenna, dorsal view, $\times 25, C$ Merus and carpus of third maxilliped of left side, ventral view, $\times 19$, D Sternum of third maxilliped, $\times 12$.

Chelipeds subequal in both sexes, almost smooth beneath tomentum, but partly granulated; arm has an acuminate tooth at 
distal end of anterior margin, distal margin of upper surface, where it articulates with the wrist, armed with two acute spinules; distal margin of ventral surface armed with similar spinules near anterior margin, and posterior end prolonged into an acuminate tooth; wrist armed with sharply pointed teeth three to eight in number and alternately large and small, the large one sometimes being subdivided; rugose posterior margin prolonged into an acuminate tooth and provided with a few spinules or tubercles, distal margin of wrist armed with an acuminate tooth between the median sinus and the postero-distal tooth just named; outer margin of palm serrated and armed with about ten spinules beneath the marginal series of cilia, five or six of them in proximal part rather large, a few tubercles situated along the series of above-mentioned spinules; inner margin of palm armed with one acuminate tooth at distal end; upper surface of palm in inner

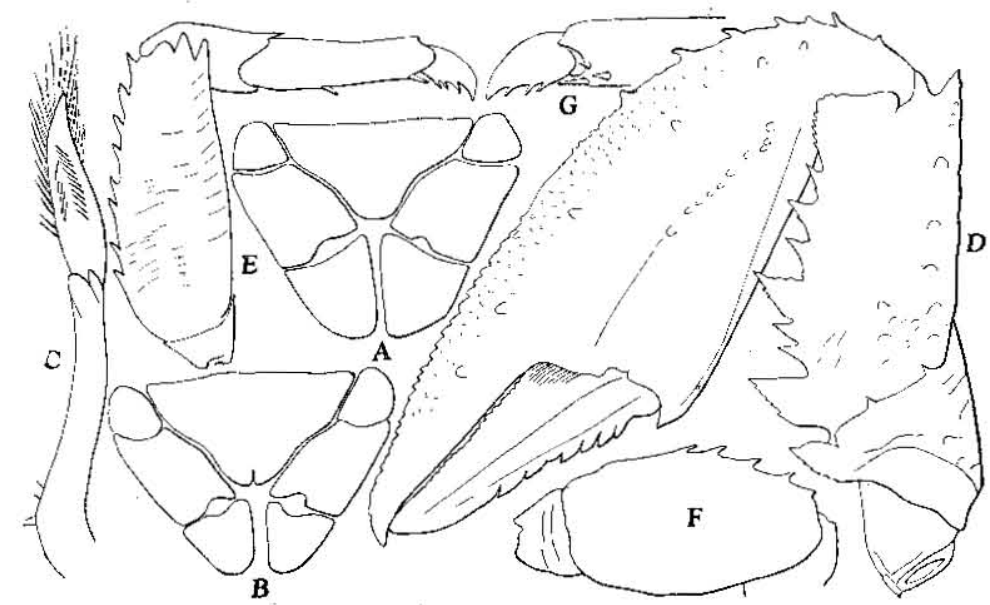

Fig. 21. Petrolisthes tomentosus (Dana).

A Telson of female, $\times 10, \quad B$ Same of male, $\times 10, \quad$ C Abdominal appendage of male, $\times 20, \quad \mathrm{D}$ Dorsal face of right cheliped of male, $\times 6, \quad \mathrm{E}$ First ambulatory leg of right side, dorsal view, $\times 6, \quad \mathrm{~F}$ Merus of third ambulatory leg, ventral view, $\times 6$.

half smooth, polished beneath tomentum, but ornamented with fine granules in outer half becoming gradually larger outwards, five to eight tubercles along the series of above-mentioned spinules; inner 
margin of immovable finger smooth, while that of movable finger minutely dentate; outer margin of movable finger serrate.

Ambulatory legs sparsely hairy; anterior margin of merus of first three pairs armed with a few spines; the posterior margin usually armed with two small teeth, sometimes three more teeth present at distal end; that of third pair unarmed; carpus of first pair armed with one spinule at distal end of outer margin; that of second and third pairs unarmed in our specimens; propodus armed with four spinules on inner margin: two of them at distal end, dorsal one of which being larger, one before them in usual position, the remaining one before the middle of the segment; dactlylus armed with three spinules which increase in size distally.

Telson of abdomen seven-jointed, the telson of male shorter than that of female, median plate of male longer than that of female, lateral plates of male smaller than those of female.

Colour in life: Colour above bluish-white, with purplish brown spots arranged with regular intervals, the carapace having four such spots about in the middle and others near the margin; legs with four or five spots; white beneath.

Colour in alcohol: Dorsal face yellowish white, ventral face white.

Habitat: Found under rocks near lower tide-marks or in coral reefs.

Material examined:

Mesima I., Danzyo-Group, Nagasaki-ken, 19, May 22, 1935 (H. HORI).

Kagosima, $1 \hat{\delta}$, in the Seventh High School, Kagosima.

Maézato Isigaki I., Yaéyama-Group, Ryūkȳū, 1ో, May 20, 1940

(MIYAKE).

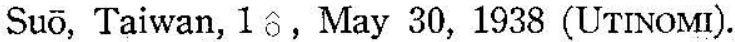

Dimensions (in mm):

Length of carapace

Breadth of carapace

Length of wrist Breadth of wrist o (Isigaki I.)

7.5

7.3

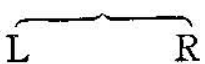

5.0

2.5
4.8

2.4
우 (Mesima I.)

6.5

6.4

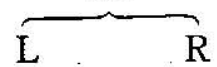

$4.0 \quad 3.0$

$1.5 \quad 1.5$ 
Length of wrist Breadth of wrist

$\begin{array}{llll}2.0 & 2.0 & 2.6 & 2.0 \\ 8.5 & 7.5 & 5.5 & 4.8 \\ 4.5 & 4.3 & 2.3 & 2.6 \\ 1.88 & 1.74 & 1.85 & 1.84 \\ 4.3 & 3.8 & 2.7 & 2.5\end{array}$

Length of palm

Breadth of palm

Length of palm

Breadth of palm

Length of finger

Distribution: Paumotu Is.; Nippon: Mesima I. (northern limit); Kagosima; Amami-Ōsima; Isigaki I.; Ogasawara Is.

10. Petrolisthes fimbriatus BoRRADAILE

Text-fig. 22 .

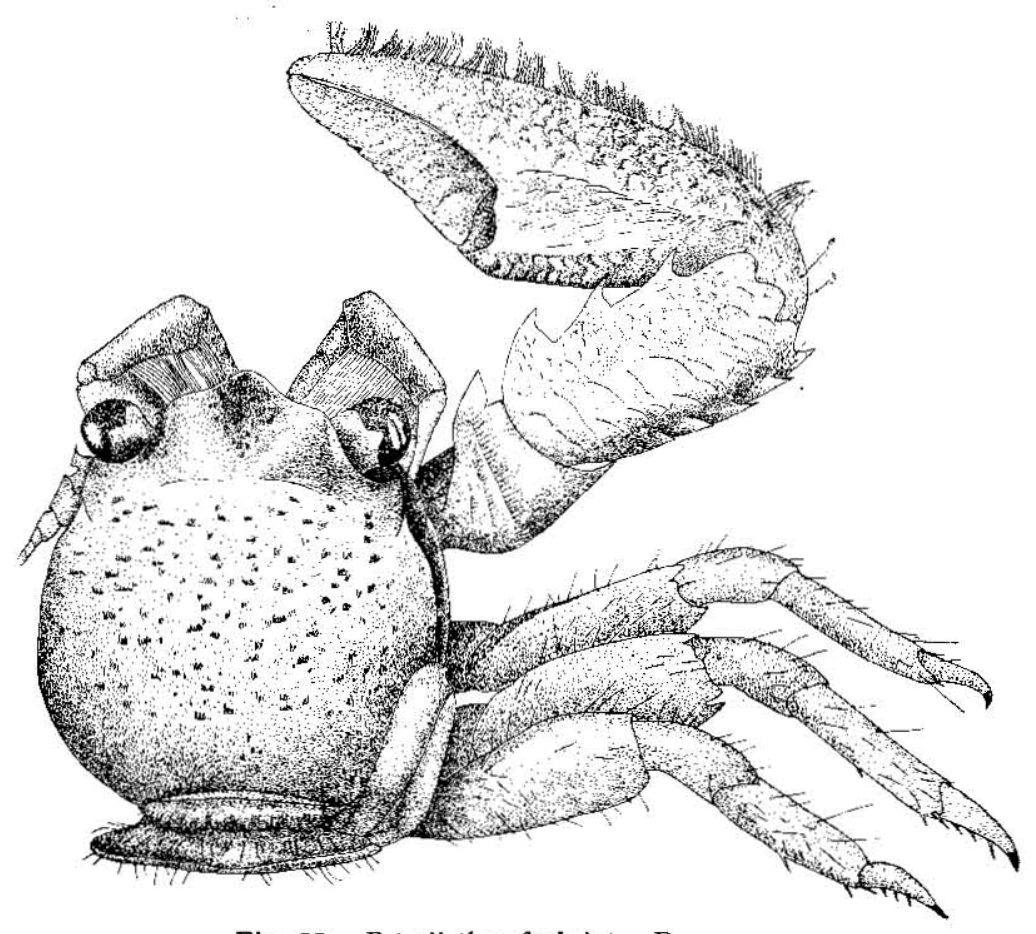

Fig. 22. Petrolisthes fimbriatus BorradaILE, male, $\times 10$ (after Mryake)

Petrolisthes lamarckii var. fimbriatus BoRRADAILE 1898, p. 466; p. 467, Pl. 36, fig. 2-Ellice Is.; Rotuma Is.

Petrolisthes fimbriatus MIYAKE 1942, p. 339, text-figs. 5-6-Micronesia:

Palau Is.; Kusaie. 
Material examined:

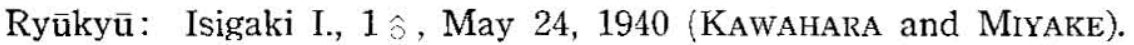
Micronesia: Palau and Kusaie Is., $9 \hat{b}$ 소, 3 우 우, 4 ovig. 우 우 (reported in my previous paper, 1942).

Dimensions (in $\mathrm{mm}$ ):

Isigaki $\mathrm{I}$.

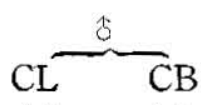

$\underset{\mathrm{CL}}{\stackrel{\text { ovig. }+9}{\mathrm{CB}}}$

Palau Is.

$\begin{array}{ll}4.5 & 4.5 \\ 6.0 & 6.1\end{array}$

5.3

5.3

6.0

5.3

5.6

Distribution: Ellice Is., Rotuma Is., Micronesia, Isigaki I., Ryūkyū (northern limit).

11. Petrolisthes boscii (Audouin et SAvigny)

Text-figs. $23-24$.

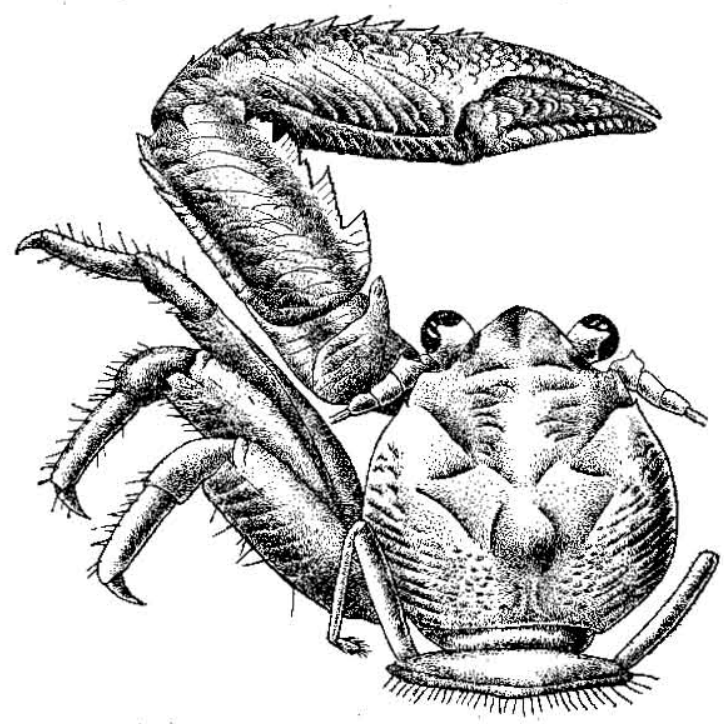

Fig. 23. Petrolisthes boscii (Audoun et Savigny), male, $\times 3$.

Porcellana boscii Audouin et SAvigny, Description de l'Egypte, Crust., Paris 2. Edit., 1826, Pl. 7, fig. 2-Red Sea (Typelocality).

Heller 1861, p. 256-Red Sea.

DE MAN 1881, p. 104-Red Sea. 
Porcellana (Petrolisthes) boscii DE MAN 1882, p. 217-Mergui Is. Petrolisthes boscii Kossman 1877, p. 74-Red Sea.

ralia.

HENDERSON 1893, p. 427-Kurachi; North Aust-

Ortmann 1897, p. 284-No new locality.

NoBiLi 1906, p. 130-Red Sea.

....... ........ BALSS 1913, p. 29, Pl. 1, fig. 4-Nippon: Satuma,

Suruga.

........ ........ Mryake 1937d, p. 211, text-fig. 1; Pl. 12, fig. 2Tanabe Bay.

Carapace depressed, as long as broad in larger specimen, but a little longer than broad in smaller specimen; upper surface almost smooth, gastric region ornamented with various forms of flattened granules and striae which are furnished with microscopical hairs anteriorly. Front triangular, with the apex deflexed downwards and concave above. Lateral margin distinct, rounded posteriorly; epibranchial spine acuminate. Epimera ornamented with longitudinal striae.

Antennule: First peduncle of antennule broader than long, its anterior margin toothed, and provided with two acuminate teeth on both extremities; ventral surface slightly punctate or striated. Antenna: Second peduncle furnished with a prominent crest anteriorly, its margin undulated and pointed at proximal end, a short joint present between the second and third peduncles; second peduncle granulated on ventral surface, and ornamented with microscopical hairs on subdistal margin; fourth peduncle covered with similar hairs distally. Their relative lengths are II : $\mathrm{III}: \mathrm{IV}=5: 6: 5$. Third maxilliped: Merus ornamented with transverse striae, its laminate crest almost symmetrical; carpus elongated, and provided with a groove near the outer margin; sternum of third maxilliped trilobed, the central process very broad, its margin straight; lateral process rounded.

Chelipeds almost equal; arm has a long tooth at the inner extremity, its distal margin provided with three spines, two of which situated above, the other below; wrist armed with five sawteeth on anterior margin, the rugose posterior margin with three spines at distal part, the upper surface of wrist ornamented with squamiform granules with minute or microscopical hairs; upper surface of palm furnished with similar granules which gradually 
pass into small ones becoming acute on the outer margin; fingers much shorter than palm and their tips cross each other, the inner margins furnished with hairs, and no gap between the fingers.

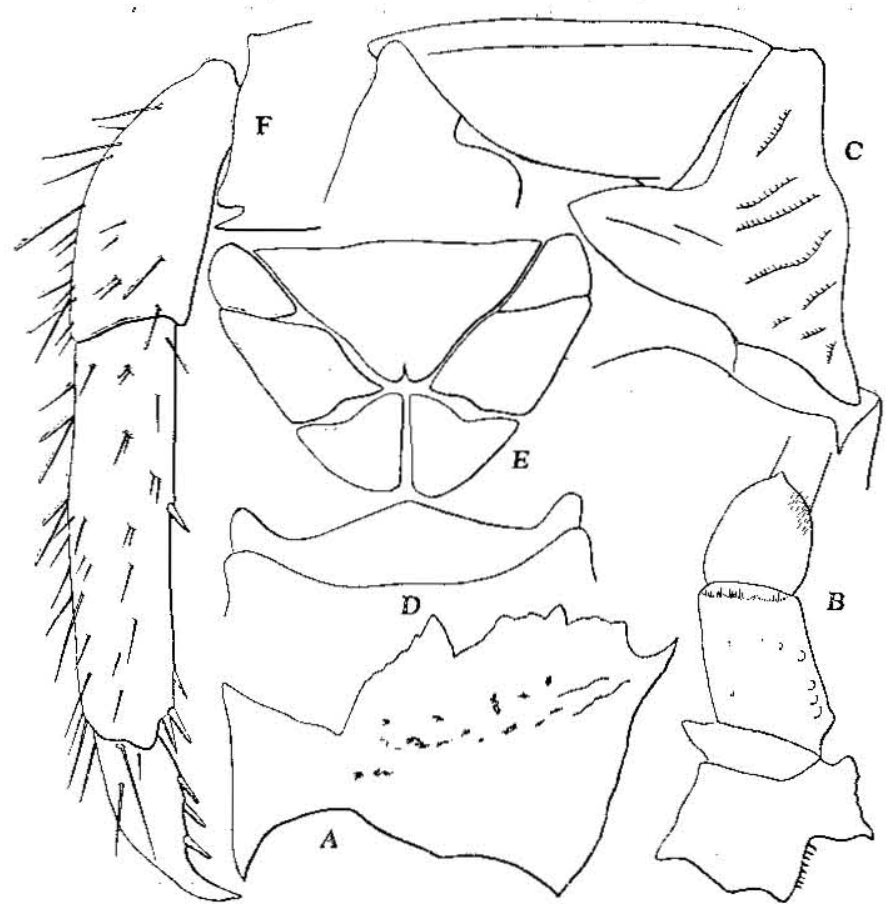

Fig. 24. Petrolisthes boscii (Audour et Savigny).

A First peduncle of left antennule, ventral view, $\times 25, \quad$ B Basal peduncles of left antenna, ventral view, $\times 12, \mathrm{C}$ Merus and carpus of third maxilliped of left side, ventral view, $\times 12, \quad \mathrm{D}$ Sternum of third maxilliped, $\times 7.5, \quad \mathrm{E}$ Telson of male, $\times 7.5$, $\mathrm{F}$. Second ambulatory leg of left, side, $\times 7.5$.

Ambulatory legs somewhat hairy; merus furnished with transverse, squamiform granules; the first two pairs armed with an acute spine at distal end of posterior margin; the third pair unarmed; propodus provided with four spinules on posterior margin; dactylus with three spinules. Telson of abdomen seven-jointed, central plate very broad.

Colour in alcohol: Whitish. 
Habitat: Found under rocks at low tide.

Material examined:

Seto, Prov. Kii ; 1 if, S. M. B. L., IX J. Cat. No. 17, Apr. 3., 1936 (UTINOMI).

Prov. Tosa, 1 s, Oct. 17, 1941 (IsIKawa).

Dimensions (in mm):

Length of carapace

$\begin{array}{cc}1 \text { (Kii) } & \text { (Tosa) } \\ 11.5 & 14.0 \\ 11.0 & 14.2\end{array}$

Distribution: Red Sea; Mergui Is.; North Australia; Nippon: Suruga Bay, Prov. Kii, Prov. Tosa, Prov. Satuma.

12. Petrolisthes masakii sp. nov.

Text-fig. 25-26.

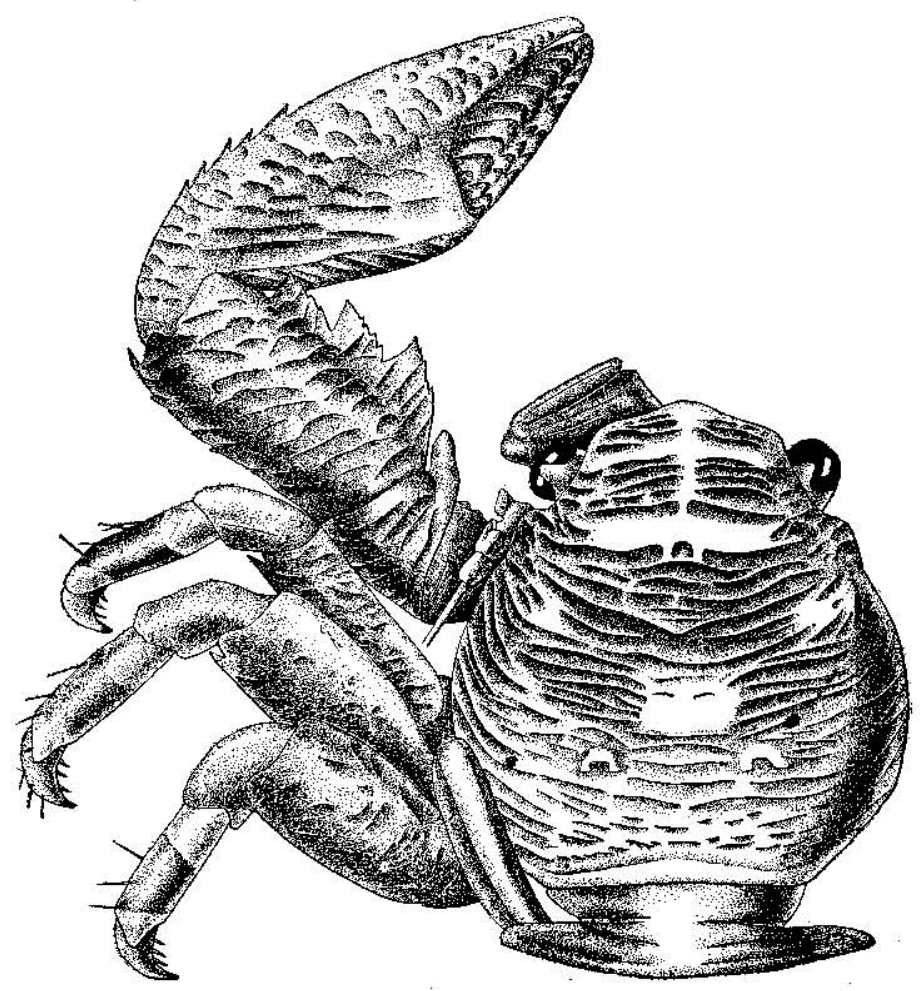

Fig. 25. Petrolisthes masakii sp. nov., male (holotype), $\times 12$. 
Carapace depressed, a little longer than broad; upper surface smooth, ornamented with transverse crests which are furnished with microscopical hairs anteriorly on all regions. Front rather broad, triangular, with apex very much deflexed downwards. Posto-ocular lobe much produced laterally; lateral margin expanded

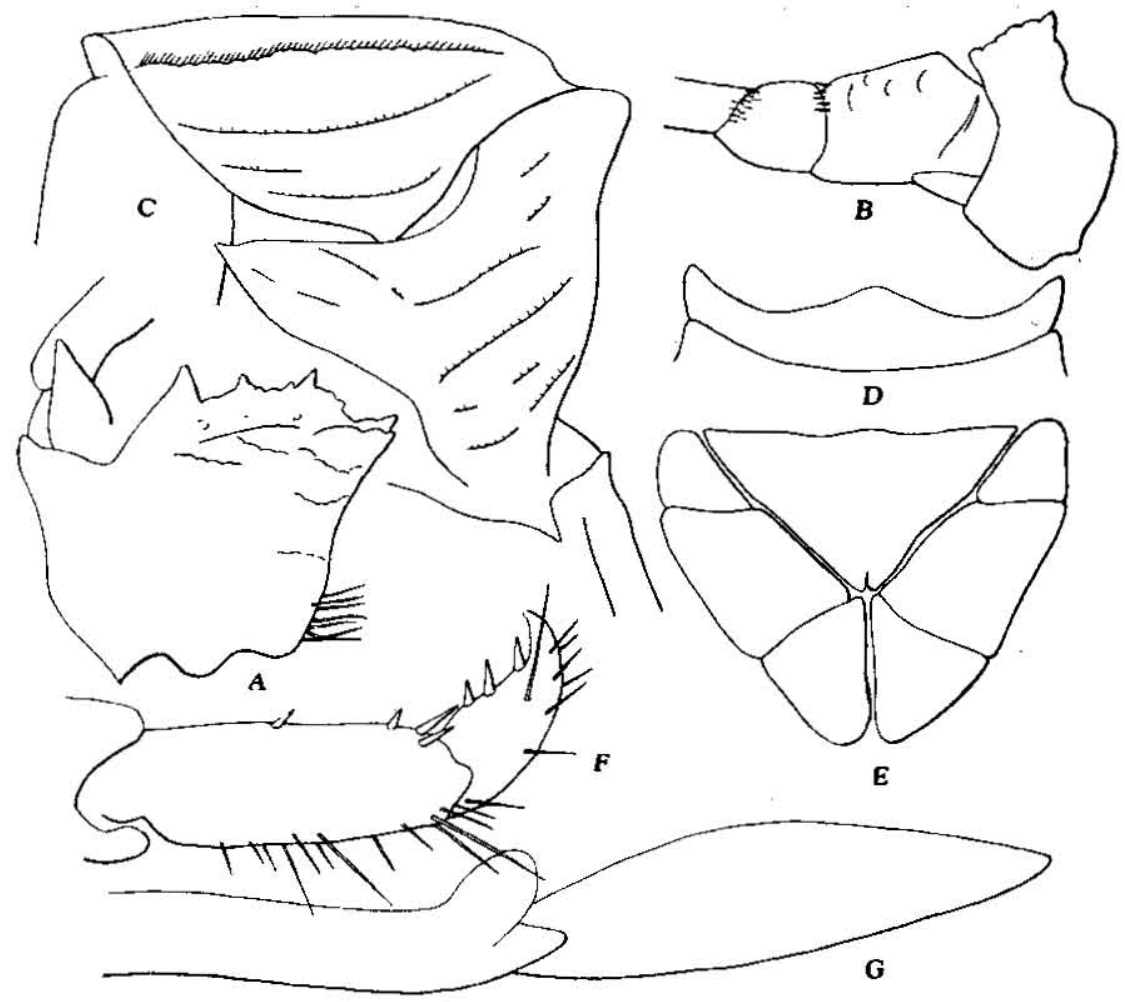

Fig. 26. Petrolisthes masakii sp. nov.

A First peduncle of left antennule, ventral view, $\times 53, \quad B$ Basal peduncles of left antenna, ventral view, $\times 53, \quad \mathrm{C}$ Merus and carpus of third maxilliped of left side, ventral view, $\times 53$, D Sternum of third maxilliped, $\times 33, \quad \mathrm{E}$ Telson of holotype, $\times 33, \quad F$ Dactylus and propodus of second ambulatory leg, ventral view, $\times 33, \quad \mathrm{G}$ Abdominal appendage of holotype, $\times 100$.

and rounded; there is no epibranchial spine. Antennule, antenna and third maxilliped are similar respectively to those of $P$. boscii. Chelipeds unequal; arm has a long tooth at the inner extremity, its distal margin unarmed; wrist armed with only three saw-teeth 
on anterior margin in both sides, the rugose posterior margin with two spines at distal part; outer margin of palm armed with five spines, while there are about twelve spines in P. boscii; ornamentation of upper surface of cheliped closely resembles that of $P$. boscii. Ambulatory legs broader than that of $P$. boscii.

This species appears to be closely allied to $P$. boscii, but it can be distinguished at first sight from $P$. boscii by the striking ornamentation of carapace, broader cheliped and ambulatory legs. This species is destitute of epibranchial spine which may be hardly of any specific importance. In regard to the absence or presence of epibranchial spine in P. lamarckii and P. lamarckii var. rufescens, BORRADAILE and LAURIE suggest that the absence of epibranchial spine has a strong tendency of associating with the presence of a larger number of anterior wrist-teeth. This new species, however, bears a smaller number of anterior wrist-teeth. Although the specimen is of small size, it probably is quite mature.

Colour in alcohol: Body of a yellowish white colour, and transverse crests reddish.

Material examined: Maézato, Isigaki I., Ryūkyū, 1 ô (holotype), deposited in the Zoological Laboratory, Kyūsyư Imperial University, May 20, 1940, collected by Mr. Tutomu MasákI.

Dimensions (in $\mathrm{mm}$ ):

\begin{tabular}{llc} 
Length of carapace & \multicolumn{2}{r}{$\begin{array}{l}4.1 \\
\text { Breadth of carapace }\end{array}$} \\
Length of wrist & 1.85 & 1.66 \\
Breadth of wrist & 1.4 & 1.25 \\
Length of palm & 1.9 & 1.7 \\
Breadth of palm & 1.66 & 1.5 \\
Length of finger & 1.5 & 1.3
\end{tabular}

\section{Petrolisthes asiaticus (LEACH)}

Text-fig. 27.

Pisidia asiatica LEACH, Dict. Sci. Nat., vol. 18, 1820, p. 54-Mauritius (Type-locality).

Porcellana asiatica H. MILNE-EDWARDS 1837, p. 252-Mauritius. 
Richters 1880 p. 159, Pl. 17, fig. 13--Mauritius.

Petrolisthes lamarckii var. asiaticus MIERS 1884, p. 269; p. 557North Australia.

Ellice Is.; Rotuma Is.

Petrolisthes asiaticus DE MAN 1896, p. 376, Pl. 32, figs. $48_{\mathrm{a}-\mathrm{b}}-$ Atjeh, North Sumatra.

DE MAN 1902, p. 694-Ternate, Moluccas.

SENDLER 1923, p. 41-Palau Is.

Mryake 1942, p. 335, text-figs. 1-2-Micronesia.

Petrolisthes yaeyamensis Mryake $1937_{c}$, p. 157, text-fig.-Isigaki I., Yaéyama-Group, Ryūkyū.

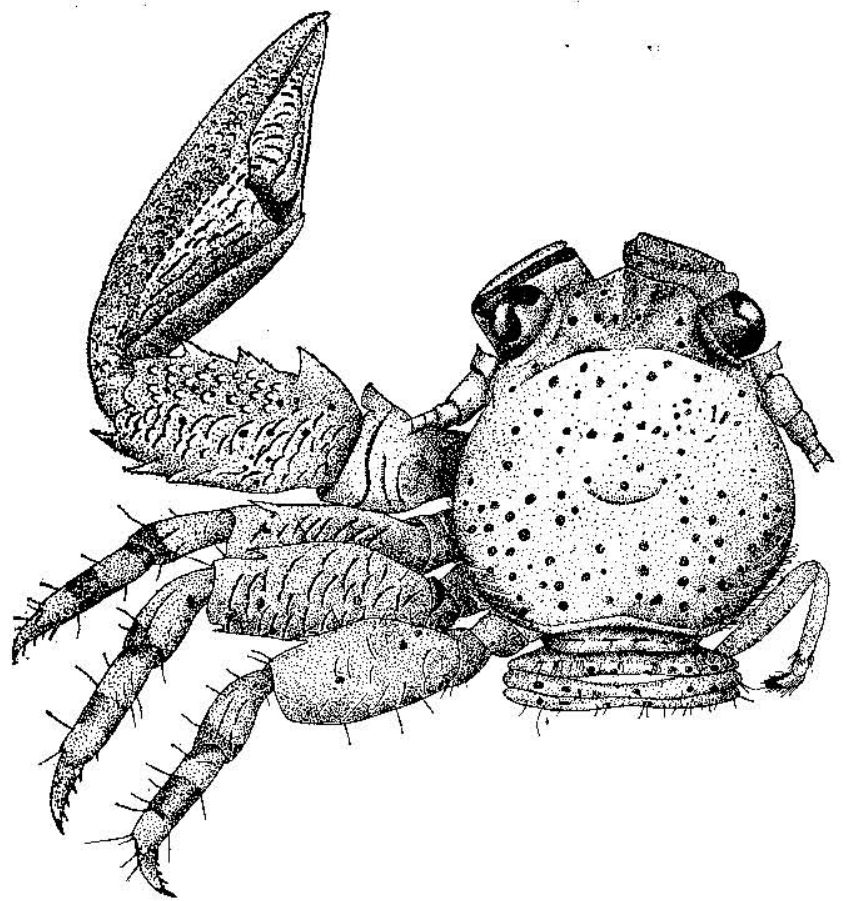

Fig. 27. Petrolisthes asiaticus (L $\mathrm{L}_{\text {:ACII }}$ ), male, $\times 7.5$ (after MrYake).

Material examined:

Ryükyū: Isigaki I., $11 \hat{\mathrm{s}} \hat{\circ}, 7$ ovig. 우 9,4 위 (MASAKI) $;{ }_{s}^{3} 2 \hat{\jmath}$ o, 5 ovig. 9 . 1 , 1 , May 25, 1940 (KAWAHARA and MiYaKe).

Micronesia: Palau, Tokobei and Kusaie Is., 11 ô 1 , 5 qㅜㅎ, 16 ovig. 우 후 (reported in my previous paper, 1942). 
Dimensions (in $\mathrm{mm}$ ):

\begin{tabular}{|c|c|c|c|c|c|c|}
\hline & \multicolumn{2}{|c|}{$\hat{0}$} & \multicolumn{2}{|c|}{ ovig. ㅇ } & \multicolumn{2}{|c|}{ ? } \\
\hline & $\overparen{\mathrm{CL}}$ & $\mathrm{CB}$ & $\overparen{C L}$ & $\mathrm{CB}$ & $\overparen{\mathrm{CL}}$ & $\overline{\mathrm{CB}}$ \\
\hline Isigaki I. & 11.5 & 11.5 & 13.3 & 13.0 & 5.0 & 4.8 \\
\hline , & 11.5 & 11.4 & 11.5 & 11.5 & 5.0 & 5.0 \\
\hline , & 10.2 & 10.2 & 9.8 & 9.8 & 4.3 & 4.1 \\
\hline Palau Is. & 8.0 & 8.0 & 9.2 & 9.5 & 7.9 & 8.6 \\
\hline , & 7.6 & 7.6 & 7.9 & 8.1 & 6.5 & 6.3 \\
\hline
\end{tabular}

Distribution: Mauritius, Sumatra, Micronesia, Ellice Is., Paumotu Is., North Australia, Ryūkyū.

14. Petrolisthes moluccensis (DE MAN) Text-fig. 28.

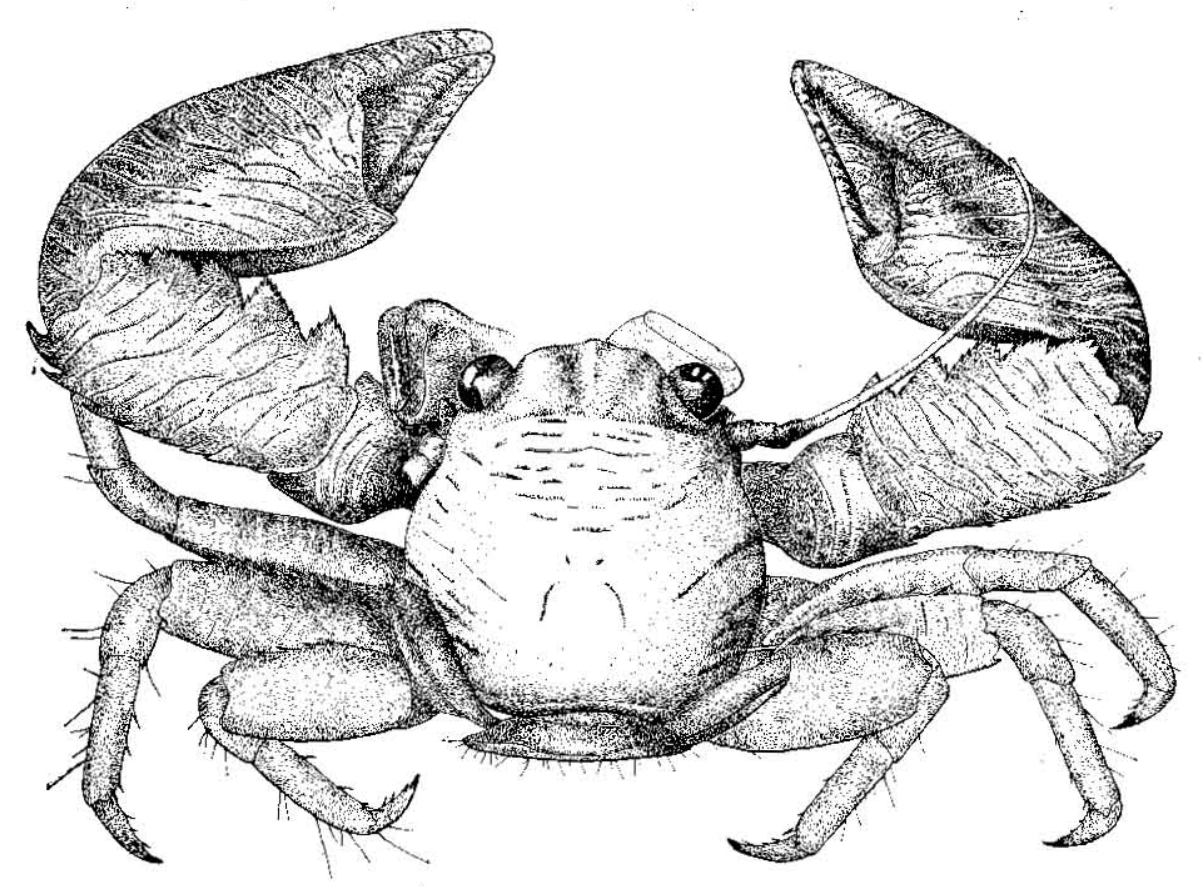

Fig. 28. Petrolisthes moluccensis (Dr Mar), male, $\times 10$ (after MiYakf).

Porcellana (Petrolisthes) moluccensis DE MAN $1888_{\mathrm{b}}$, p. 411, Pl. 12, fig. 5-Amboina (Type-locality).

Petrolisthes moluccensis DF MAN 1896, p. 378-No new locality. 
............... MiYAKe 1942, p. 337, text-figs. 3-4-Palau Is.

Material examined:

Ryūkyū: Isigaki I., 3 占令, 1 우, infested by Bopyrus, 1 ovig. + , May 20, 1940 (KAWAHARA and MiYAKE).

Palau Is., $7 \hat{\circ}$ o, 1 ovig. ㅇ, 1 ? (reported in 1942).

Dimensions (in $\mathrm{mm}$ ):

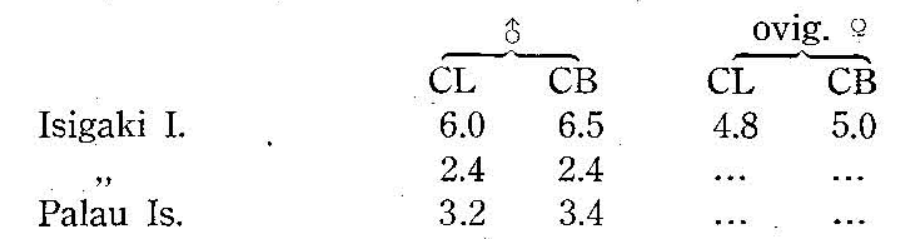

Distribution: Amboina, Palau Is., Isigaki I. (present paper).

\section{Petrolisthes lamarckii (LEACH) \\ Text-fig. 29.}

Pisidia lamarckii LEACH 1820, p. 54.

not Porcellana Lamarckii H. MLLne-EdwnRds 1837, p. 251 (syn.

Petrolisthes hastatus STIMPSON).

Petrolisthes lamarckii BORRADAILE 1898, p. 464; p. 465, P1. 36, figs.

1, $1_{\mathrm{a}}$-Ellice Is., Rotuma Is.

.............. Marcus 1911, p. 533, text-figs. 14-15; Pl. 26, fig.

3-Locality unknown.

.............. GORDON 1931, p. 526-Hongkong.

.............. MiYake 1942, p. 342, text-figs. 7-8-Micronesia.

Porcellana dentata H. MILNE-EDwards 1837, p. 251-Java.

Porcellana (Petrolisthes) dentata DE MAN 1888, p. 216; 1896, Pl. 32 , fig. $47_{b}-$ Mergui Is.

..................... DE MAN 1888 b. p. 409, Pl. 12, fig. 7-Java. Petrolisthes dentatus var. DE MAN 1896, p. 374, Pl. 32, figs. $47_{\mathrm{a}}$, $48_{c}$-Atjeh, North Sumatra.

Petrolisthes dentatus Haswejt 1882, p. 146-Port Denison, Queensland.

............... HENdERSON 1893, p. 426-Indian Ocean.

.............. RathBun 1910, p. 314-Moluccas; Amboina.

............... Sendier 1923, p. 41-Palau Is.

Porcellana speciosa DANa 1852, p. 417, p. 26, fig. 8-Sulu Sea; Paumotu; Ōtori-sima (=Wake I.). 
Petrolisthes speciosus STIMPSON 1858, p. 227; p. 241; 1907, p. 182, P1. 22, fig. 2-Kagosima Bay; Amami-Ōsima; Ogasawara Is. ........ ........ ORTMANn 1892, p. 262-South Sea; East Australia. …........... BALSS 1913, p. 30-Ogasawara Is.

Petrolisthes sp. PARISI 1917, p. 7-Ōtori-sima.

Porcellana bellis Heller 1865, p. 76, Pl. 6, fig. 4-Nicobars.

Petrolisthes obtusifrons MiYAKE 1937 , p. 155, text-fig.-Isigaki I.

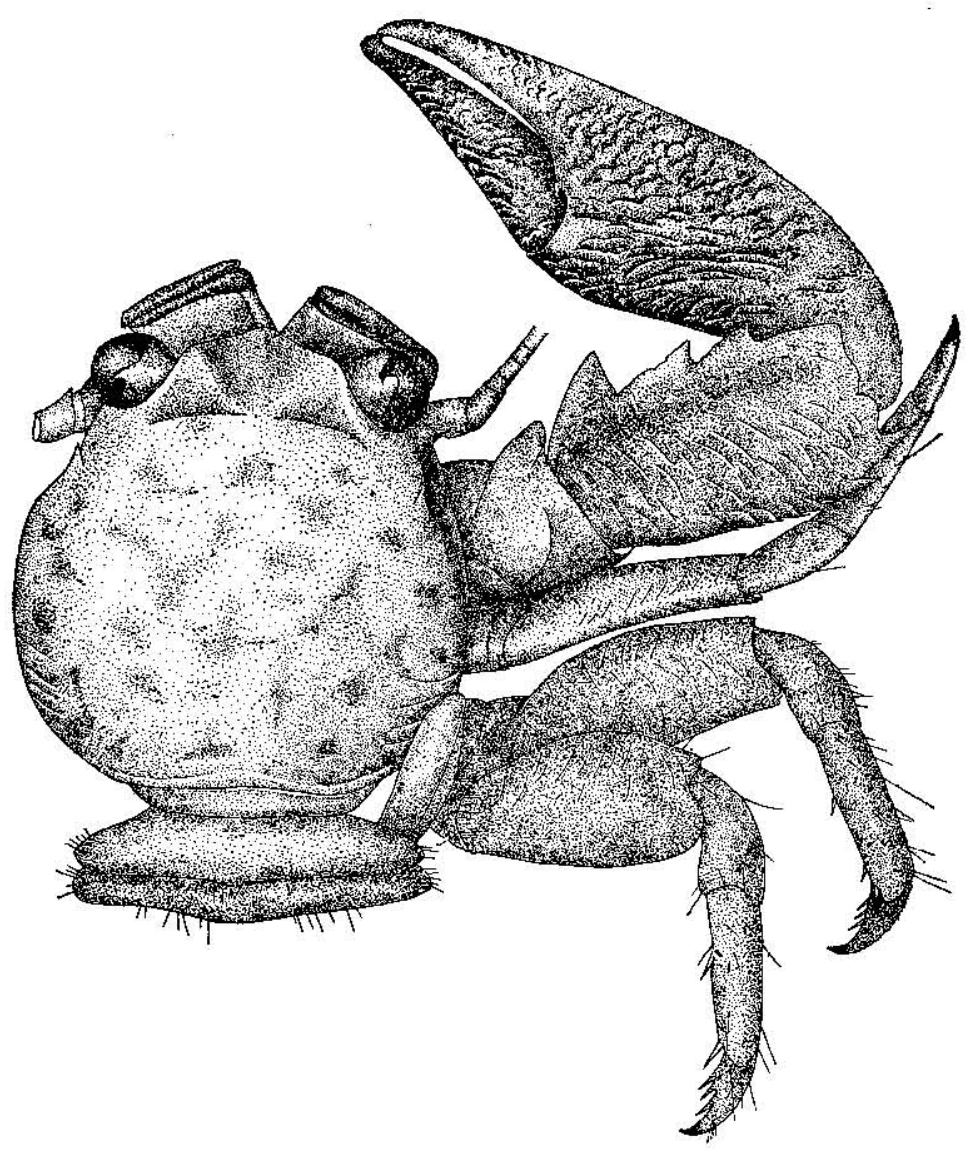

Fig. 29. Petrolisthes lamarckii (LEACH), male, $\times 7.5$ (after Mryake).

Material examined:

Amami-Ōsima, 1ㅅ․ Sept. 22, 1934 (TAKESITA).

Isigaki I., $12 \hat{\text { o }} \hat{\mathrm{o}}, 16$ ovig. 우 우, $7 \stackrel{9}{\circ}$ 우 (MASAKI); $13 \hat{s} \hat{b}, 14$ ovig. 


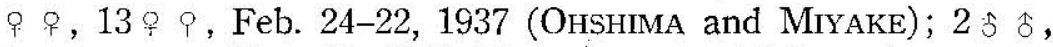
3 ovig. 우 우, May 22, 1940 (KAWAHARA and MrYaKe)

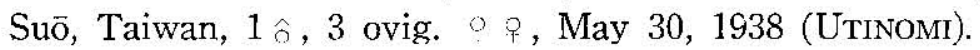

Ogasawara Is., 1 ovig. '尹 , deposited in the Tōkyō Science Museum, Cat. No. 400.

Micronesia: Palau, Tokobei, Kusaie and Jaluit Is., $20 \hat{\circ}\}$, 8 우 우, 35 ovig. 우 우 (reported in my previous paper, 1942).

Dimensions (in $\mathrm{mm}$ ):

\begin{tabular}{|c|c|c|c|c|c|c|}
\hline & \multicolumn{2}{|c|}{ 令 } & & \multicolumn{2}{|c|}{ ovig. ㅇ } \\
\hline & $\mathrm{CL}$ & $\mathrm{CB}$ & $\mathrm{CL}^{-}$ & $\mathrm{CB}$ & $\mathrm{CE}$ & $\mathrm{CB}$ \\
\hline Amami-Ōsima & 16.8 & 17.0 & $\ldots .$. & ....... & ....... & ...... \\
\hline Jsigaki I. & 8.5 & 8.3 & 8.3 & 8.0 & 8.5 & 8.5 \\
\hline$"$ & 8.0 & 7.8 & 6.8 & 6.5 & 6.0 & 6.2 \\
\hline " & 7.5 & 7.5 & 4.3 & 4.2 & 4.0 & 4.0 \\
\hline Suō, Taiwan & 3.1 & 3.0 & ...... & $\ldots \ldots$. & 3.6 & 3.5 \\
\hline Ogasawara Is. & & & & ....... & 9.0 & 9.0 \\
\hline
\end{tabular}

Distribution: Indian Ocean, East Australia, East Indian Ocean, Polynesia, Micronesia, Sulu Sea, Hongkong, Ogasawara Is., Otorisima, Taiwan, Ryūkyū, Amami-Ōsima, Kagosima Bay.

\section{5a. Petrolisthes lamarckii var. rufescens (Heller) Text-fig. 30.}

Porcellana rufescens Heli.er 1862, p. 255, PI. 2, fig. 4; 1865, p. 76 -Tahiti (Type-locality).

Petrolisthes lamarckii var. rufescens BoRRADAILE 1898, p. 465; p. 467-Ellice Is; Rotuma Is.

figs. 9-10-Micronesia.

Petrolisthes rufescens NoBILI 1906, p. 130--Red Sea.

........ ........ NoBILI 1907, p. 377-Polynesia.

…........... Balss 1915, p. 7-Suez.

Petrolisthes dentatus ORTManN 1892, p. 262-South Sea.

Material examined:

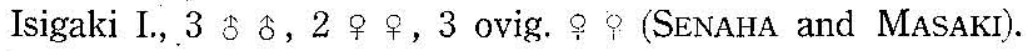

Micronesia: Palau, Kusaie and Jaluit Is., 3 하 $\hat{b}, 3$ 우 우, 3 ovig. 우 우 (reported in my previous paper, 1942). 
Dimensions (in $\mathrm{mm}$ ):

\begin{tabular}{|c|c|c|c|c|c|c|}
\hline & \multicolumn{2}{|c|}{$\hat{\delta}$} & \multicolumn{2}{|c|}{ 우 } & \multicolumn{2}{|c|}{ ovig. 우 } \\
\hline & $\mathrm{CL}^{-}$ & $\mathrm{CB}$ & $C \overparen{\mathrm{L}}$ & $\overline{\mathrm{CB}}$ & $\mathrm{CL}$ & $\mathrm{CB}$ \\
\hline Isigaki I. & 10.2 & 10.3 & 9.3 & 9.0 & 11.5 & 11.5 \\
\hline Palau Is. & 10.0 & 10.1 & 8.0 & 7.0 & 10.2 & 10.3 \\
\hline
\end{tabular}

Distribution: Red Sea, Suez, Polynesia, Micronesia, Ryūkyū (present paper).

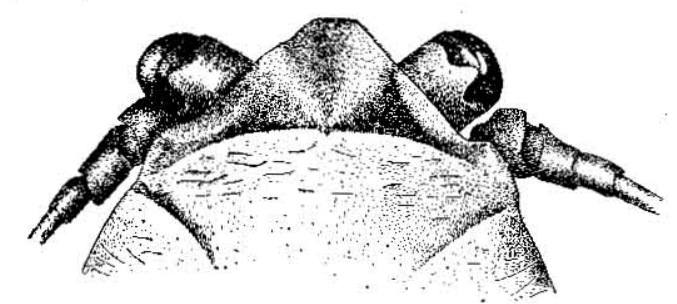

Fig. 30. Anterior part of Petrolisthes lamarckii var. rufescens (HELLER), male, × 7.5 (after MrYake).

Genus Neopetrolisthes MrYAKE

Neopetrolisthes MrYAKE 1937 a, p. 34; 1940, p. 349.

Carapace subovate, longer than broad and strongly convex in both directions, Front broad, much flattened and laminated; margin entire. Eyes small. First peduncle of antennule longer than broad. First peduncle of antenna very short; second peduncle of antenna more or less cristate. Chelipeds subequal, very short and robust. Wrist very short, being about half as long as carapace. Palm broad and flattened. Ambulatory legs short, robust, and are destitute of spines and hairs.

Type: Neopetrolisthes ohshimai MiхакE

Commensally living in the oral cavity of the gigantic seaanemone, Stoichactis kenti, on coral reefs of Ryūkyū, Palau Islands and Great Barrier Reef.

\section{Neopetrolisthes ohshimai MIYAKE}

Text-fig. 31.

Neopetrolisthes ohshimai MIYAKE 1937 a, p. 34, text-figs. 1-2Isigaki I., Yaéyama-Group, Ryūkyū. 
......... Mryake 1940 , p. 47 , Pl. 1 , fig. 8-Palau Is.

14-Palau Is.

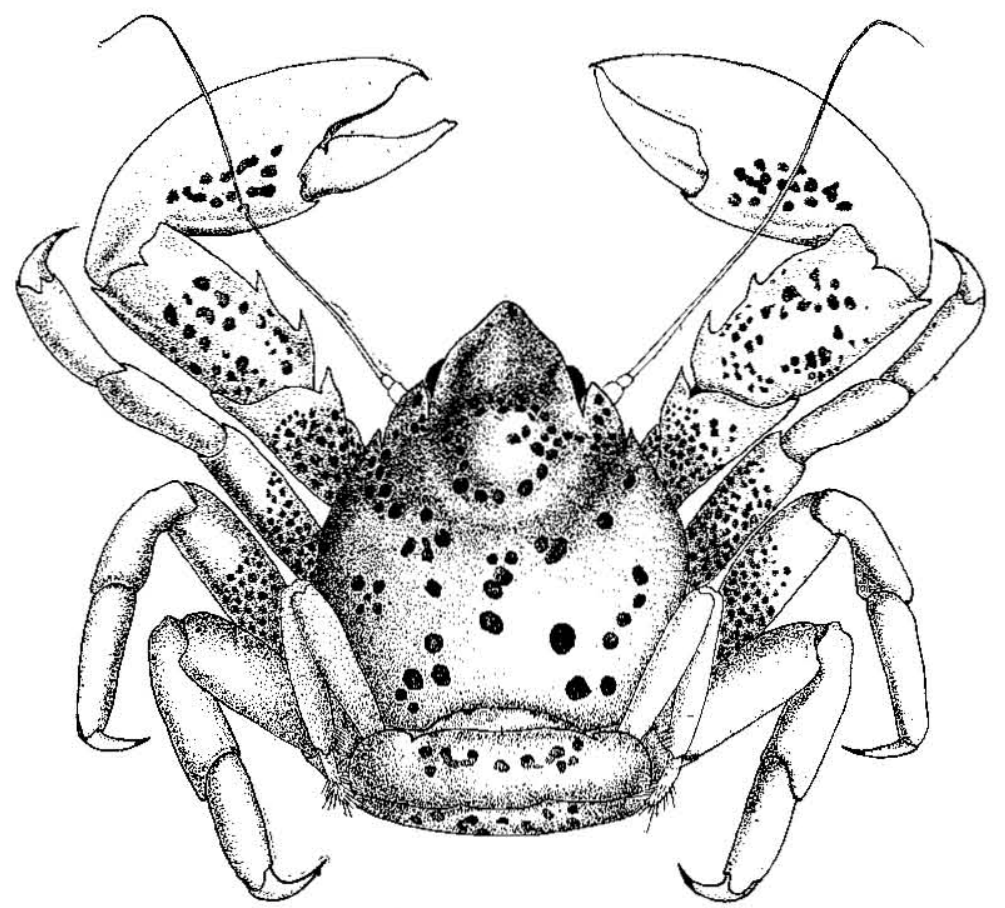

Fig. 31. Neopetrolisthes ohshimai MүуікE, female, $\times 3$ (after Miуаке).

Material examined:

Isigaki I., Ryūkyū, $3 \hat{\jmath} \hat{\circ}, 4 \rho \circ, 3$ ovig. $९$ ㅇ (MASAKI); $1 \hat{\jmath}, 1$ ovig. + , May 20, 1940 (KAWAHARA and MiYAKE).

Palau Is., 9 of $\hat{o}, 2$ ovig. $+\frac{+}{}, 2$ ? (reported in my previous paper, 1942).

Dimensions (in $\mathrm{mm}$ ):

\begin{tabular}{|c|c|c|c|c|c|c|}
\hline & \multicolumn{2}{|c|}{$\hat{0}$} & \multicolumn{2}{|c|}{ ovig. \& } & \multicolumn{2}{|c|}{ 우 } \\
\hline & $\overline{\mathrm{CL}}$ & $\overrightarrow{\mathrm{CB}}$ & $\overparen{\mathrm{CL}}$ & $\overrightarrow{\mathrm{CB}}$ & $\mathrm{CL}$ & Cl \\
\hline jig & 8.5 & 6.0 & 12.0 & 10.0 & 13.3 & 11 \\
\hline & 10.0 & 8.5 & 14.3 & 12.0 & 13.0 & 10 \\
\hline & 9.5 & 7.8 & 13.0 & 11.0 & 12.0 & 10.6 \\
\hline
\end{tabular}

Distribution: Great Barrier Reef, Palau Is., Ryūkyū. 


\section{Genus Pachycheles STimpson}

Pachycheles StimPSON 1858, p. $66 ; 1907$, p. 186. ORTMANN 1897, p. 290.

Carapace rounded-ovate, with lateral margins strongly cristate by an elevated line; upper surface of carapace smooth; front a little prominent at the middle, and subacute, but never dentate, with its apex concealed by pubescence; posterior part of epimera quadrate, and separated by a slight membranous interval from the larger anterior portion; first peduncle of antennule slightly elongated; chelipeds thick and rugose above; wrist remarkably short and broad; dactyli of ambulatory legs normal, telson five-lobed.

Type: Pachycheles grossimanus (GUE்RIN)

The genus is littoral in habits, and is an inhabitant of the temperate and warm-temperate zones in the Pacific and Indian Oceans.

Key to the species of Pachycheles

A) Cheliped without hair above, but granulated; wrist usually with three truncated teeth on anterior margin

AA) Cheliped with tomentum; wrist with two teeth on anterior margin, usually subdivided in irregular forms balssi

\section{Pachycheles stevensii STIMPSON}

Text-figs. $32-33$.

Pachycheles stevensii Stimpson 1858, p. 243; 1907, p. 187, P1. 23, fig. 6-West coast of Hokkaidō (=Jesso).

................. Miers 1879, p. 47-Strait of Tyōsen.

................ ORTMANn 1892, p. 267-Tōkyō Bay.

................. ORTMANN 1897, p. 294-No new record.

............... BALSS 1913, p. 32-Nagasaki; Vladivostock.

................ YoKoya 1928, p. 760-Mutu Bay.

........ ........ KIKUCH 1932, p. 7-Toyama Bay, Atami, Misaki, Hokkaido : Iburi, Osyoro. YoKoya 1939, p. 278-Onagawa Bay.

Pisosoma sculptum MrYaKe 1937 d, p. 217-Tanabe Bay. 
Carapace depressed, broader than long in larger specimens, but longer than broad in smaller ones; lateral margin strongly cristate, carina extending to the middle of branchial region; upper surface of carapace smooth, not areolated in the middle; on both lateral portions glabrous with transverse ridges. Sinus of the posterior margin shallow, broadly rounded, but rather sharp in larger specimens.

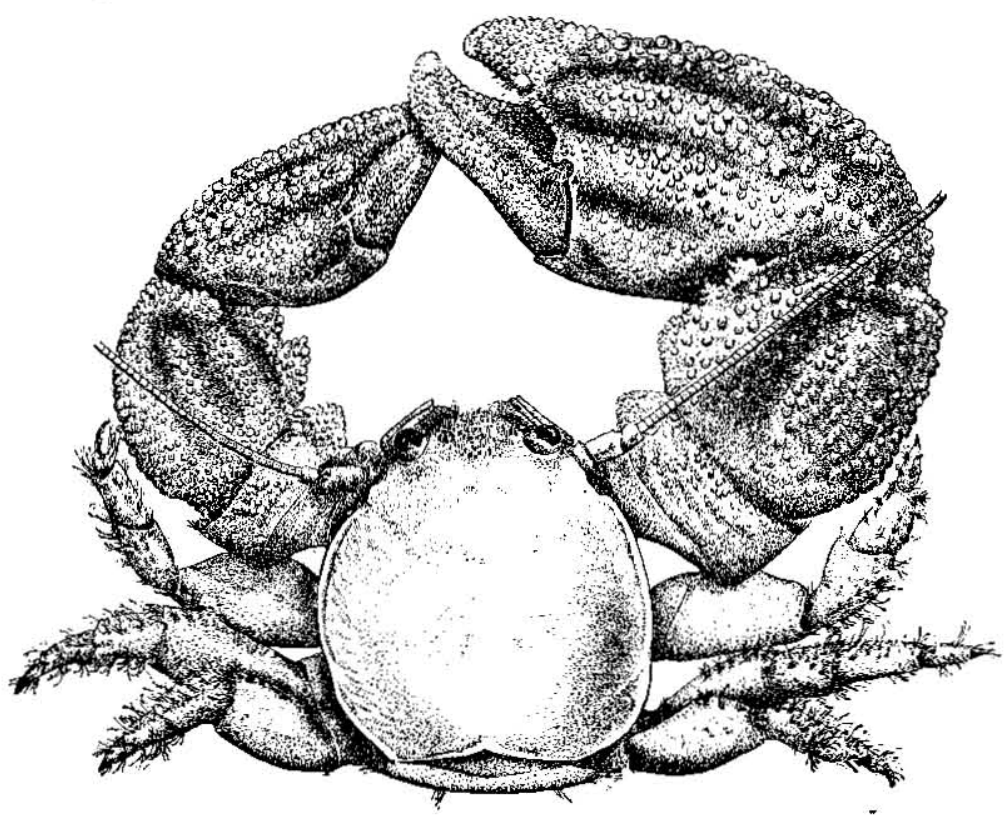

Fig. 32. Pachycheles stevensii Strmpson, male, $\times 4$.

First peduncle of antennule a little broader than long, ventral surface ornamented with a granulated line, being margined with hairs, its anterior margin of larger specimens provided with three minute teeth on inner side, a spinule produced at outer angle, while that of smaller specimens provided with granulated margin. Antennal peduncles almost smooth, cylindrical; first peduncle provided with a small tubercle on upper margin, second peduncle uneven on upper surface. Their relative lengths are II: III: IV $=$ 4: 10:3. Third maxilliped ornamented with short transverse striae on ventral surface; merus bears a laminate crest, its free margin rounded, somewhat undulated especially in larger specimens. 
Chelipeds unequal, robust ; upper and outer margins granulated, but lower margin smooth, punctate. Arm has a triangular tooth at the upper distal end, and on upper surface covered with transverse ridges which pass into granulated lines distally. Wrist

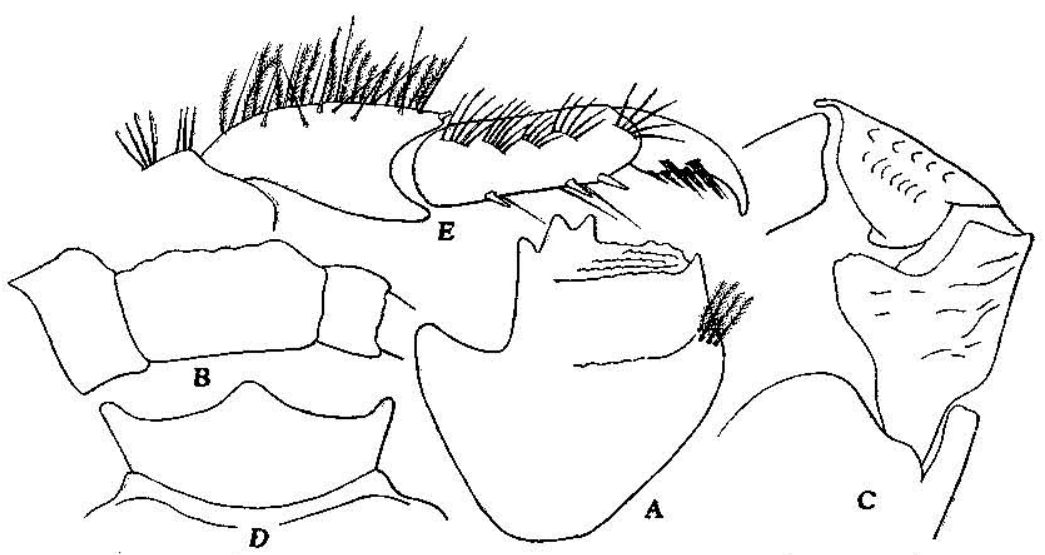

Fig. 33. Pachycheles stevensii Stimpsox.

A First peduncle of left antennule, ventral view, $x 25, \quad B$ Basal peduncies of antenna, dorsal view, $\times 12, \quad \mathrm{C}$ Merus and carpus of third maxilliped of left side, ventral view, $\times 12$, D Sternum of third maxilliped, $\times 12, \quad \mathrm{E}$ Second ambulatory leg of right side, $\times 12$.

broader than long, granulated; the granules unequal, the larger ones being arranged in more or less regular rows which are divided by three logitudinal grooves. The innermost groove largest and turns into transverse direction at subdistal margin. Anterior margin of wrist armed usually with three truncated teeth, but frequently with four or more spiniform ones. Palm also granulated, granules of outer margin rather prominent. Palm provided with three longitudinal grooves on upper surface. Fingers leave a large gap and there is a tuft of hair at the base in the larger hand, while in the smaller one no gap is formed between fingers and neither are there hairs.

Ambulatory legs robust and furnished with hairs thickly on outer margin. Carpus provided with two spinules at the upper distal end. Propodus armed with four spinules on posterior margin: two of them on the distal end in pair, one just in front of them, and the other before the middle of the segment. Propodus 
bears five or six spinules. Telson of abdomen five-jointed, the central plate being very small.

Colour in alcohol: Dorsal face light orange-yellow; ventral whitish.

Habitat: Found under stones at low tide.

Material examined:

Onahama, Hukusima-ken; 1 ovig. ơ, Cat. No. 7149, Saito Hō-on Kai Museum, 1930.

Tanabe Bay, $1 \%$, deposited in the Seto Marine Biological Laboratory attached to the Kyōto Imperial University.

In'no-sima, Prov. Bingo, Inland Sea, 2 호옹 1 ovig. 우, 1 juv., deposited in the Marine Biological Laboratory attached to the Hirosima Bunrika Daigaku, Jul. 7, 1917 (TAKI).

Prov. Tosa, 2 ovig. 우 9,1 古, Sept. 5. 1941 (IsIKaWA).

Dimensions (in $\mathrm{mm}$ ):

Length of carapace

古

Breadth of carapace

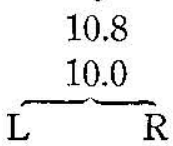

Length of wrist

$7.0 \quad 8.2$

$6.2 \quad 7.6$

$8.5 \quad 12.2$

$6.8 \quad 9.8$

$4.0 \quad 5.0$

$\begin{array}{rr}\begin{array}{c}\text { o } \\ 15.0 \\ \mathrm{~L}\end{array} & \mathrm{R} \\ 8.2 & 10.0 \\ 8.5 & 10.0 \\ 10.5 & 14.0 \\ 7.8 & 11.0 \\ 5.5 & 6.0\end{array}$

Distribution: Vladivostock (northern limit), Hokkaidō, Mutu Bay, Onahama, Onagawa Bay, Tōkyō Bay, Tanabe Bay, Inland Sea, Tosa, Nagasaki (southern limit), Strait of Tyōsen, Toyama Bay.

18. Pachycheles balssi nom. nov.

Text-figs. 34-36.

Pachycheles pubescens Balss 1913, p. 32, text-figs. 22-24-Misaki (not P. pubescens HoLmes 1900).

Carapace almost as long as broad, but very slightly longer than broad in our specimens; upper surface smooth, glabrous, not areolated in the middle, punctate or striated on both lateral portions, lateral margins almost parallel to each other and strongly cristate. 
First peduncle of antennule slightly longer than broad; outer lateral margin provided with four minute teeth; its anterior margin armed with five small teeth: one of them in the middle, the other

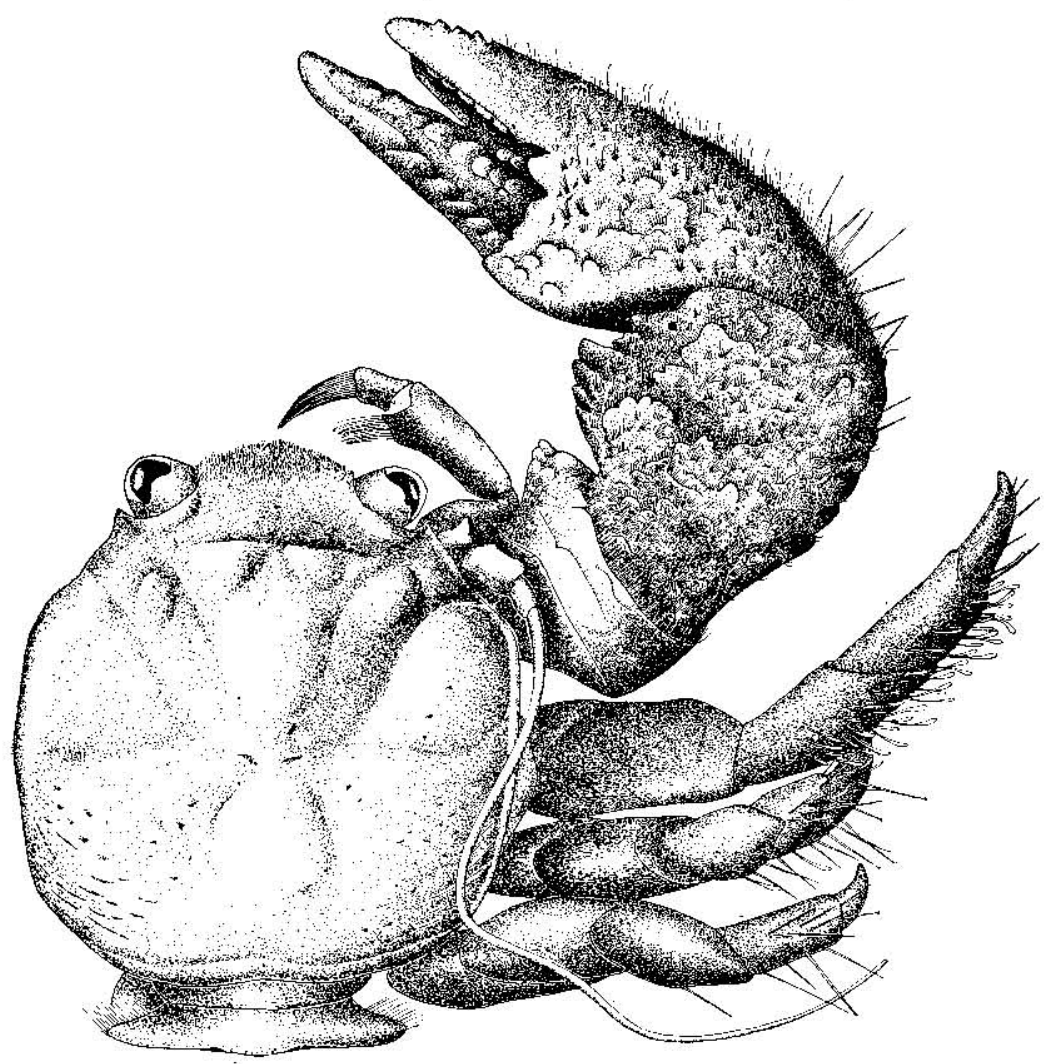

Fig. 34. Pachycheles balssi nom. nov., female, $\times 10$.

at the inner edge. Antenna smooth, glabrous; first peduncle very broad with acuminate edge on upper margin; second peduncle armed with a single spine on upper margin; upper margin of third peduncle provided with three tubercles: two of them stand near the proximal end, the other one at the subdistal end. The relative lengths of basal peduncles are II: III : IV=8: 15:7. Third maxilliped rugose or striated on ventral surface; merus ornamented with short transverse ridge, the crest of merus symmetrical, its anterior margin dentate; carpus much depressed, its ventral sur- 
face somewhat rugose or striated; sternum of third maxilliped as figured (Text-fig. $36 \mathrm{C}$ ).

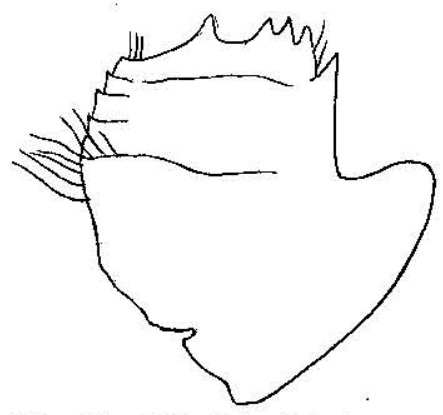

Fig. 35. Pchycheles balssi nom. nov. First peduncle of right antennule, ventral view, $\times 30$.

Chelipeds unequal; upper surface furnished with hairs and granules, or flattened squamiform scales; arm provided with a triangular tooth at the upper distal end; wrist a little longer than broad, upper surface furnished with squamiform scales beneath hairs on inner side and four or five tubercles arranged in two longitudinal rows on outer side; the inner margin armed with two teeth which are subdivided in irregular forms; palm ornamented with short hairs thickly, tubercles are scattered on inner sides; fingers granulated on upper surface, immovable finger provided with a few tubercles on outer margin.

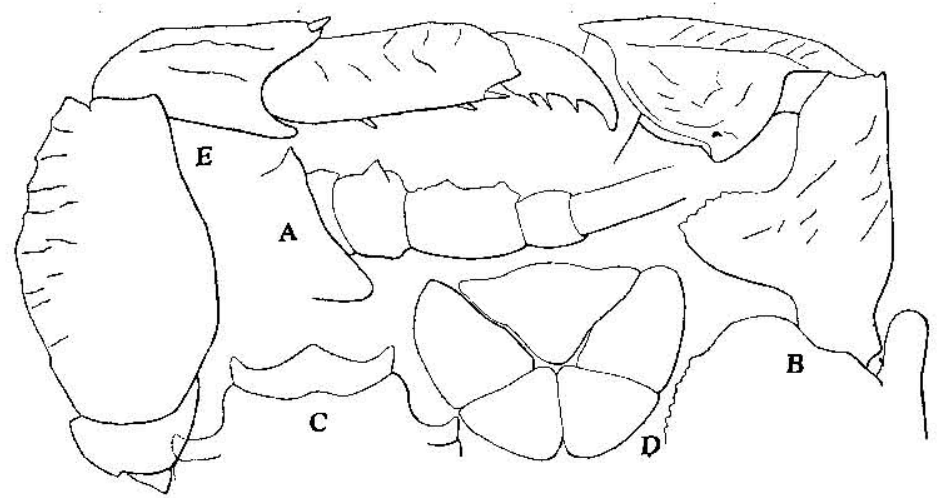

Fig. 36. Pachycheles balssi nom. nov.

A Basal peduncles of left antenna, $\times 20, \quad B$ Merus and carpus of third maxilliped of left side, ventral view, $\times 20$, C Sternum of third maxilliped, $\times 20$, D Telson of female, $\times 10$, E Second ambulatory leg of right side, dorsal view, $\times 10$.

Ambulatory legs robust, hairy; carpus of first two pairs armed with two spinules at upper distal end, that of third pair unarmed; 
propodus provided with four spinules on posterior margin: two of them at distal end, the others arranged in a longitudinal line; dactylus armed with three spinules on posterior margin.

Telson of abdomen five-jointed, antero-lateral and medio-lateral plates fused into one plate and central plate rather small.

In regard to the telson, BALss gives no mention. In the specimens from Misaki, the telson is composed of five plates, while that of Pachycheles pubescens Holmes is composed of seven plates.

Colour in alcohol: Body light yellowish brown, with brown hairs.

Habitat: Found under stones at low tide-marks.

Material examined:

Misaki, $1 \hat{o}, 1$ ovig. $?$, possessed by the Misaki Marine Biological Station (YERI); 1 ovig. $\div$ (UTINOMI).

Tanabe Bay, Prov. Kii, 1 ovig. of, in the collection of the Seto Marine Biological Laboratory (UTINOMI).

Okinosima I., Hukuoka-ken, 1 ? (holotype), deposited in the Zoological Laboratory, Kyūsyū Imperial University, May 19-29, 1933 (Ohshima, Ikeda and Yasumoto).

Dimensions (in $\mathrm{mm}$ ):

Length of carapace

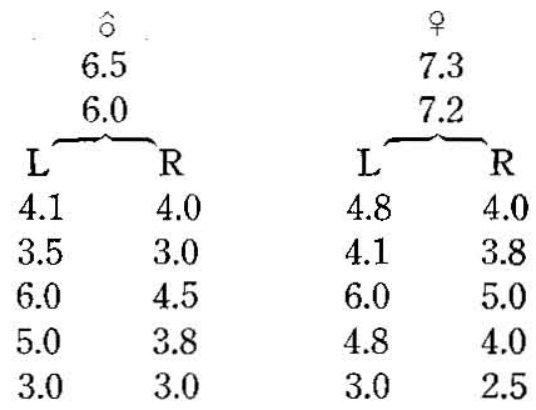

Length of wrist

Breadth of wrist

Length of palm

Breadth of palm

Length of movable finger

$3.0-3.0$

3.0

Distribution: Nippon endemic. Misaki, Tanabe Bay, Okinosima, Hukuoka-ken.

\section{Genus Pisosoma STimpson}

Pisosoma Stimpson 1858, p. 66; MiYake 1942, p. 374.

Porcellana H. Milne-Edwakds 1837, p. 253; DANA 1852, p. 412; HeLler 1865, p. 73 (in part). 
Pachycheles Miers 1884, p. 273; Henderson 1888, p. 114 ; Ortmann 1897, p. 249 (in part).

Diagnosis: Carapax rotundatus, sat convexus, non longior quam latior. Frons superne visa recta integra. Chelipedes crassi. Dactyli pedum ambulatoriorum normales (STIMPSON).

Carapace subovate, not longer than broad, median lobe of front so deflexed downwards, so that front forms an almost straight truncate margin; eyes of moderate size; antenna with small first peduncle, its second peduncle more or less cristate as in Petrolisthes; epimera composed of two pieces as in Pachycheles; chelipeds short and massive; ambulatory legs normal in form; telson fivelobed, its central segment being small.

Type: Pisosoma sculptum (H. MiLnE-EDwards)

Members of the genus inhabit under rocks of coral reefs between tide-marks and are distributed in Ryūkyū, Ogasawara Is., Philippines, East Indian Sea, Indian Ocean, Malaysia, East Africa, N. and N. E. Australia, Micronesia and Polynesia.

Key to the species of Pisosoma

A) Wrist and palm of cheliped covered with velvety tomentum especially in external half..................... fronto

AA) Wrist and palm of cheliped not hairy, but furnished with a few longitudinal grooves.

B) Palm granulated above............................ sculptum

BB) Palm smooth, not granulated ..................... pisum

\section{Pisosoma sculptum (H. MiLNE-Edwards)} Text-fig. 37.

Porcellana sculpta H. Milne-Edwards 1837, p. 253-Batavia, Java (Type-locality).

? .............. DANA 1852, p. 412; 1855, Pl. 26, fig. 2-Sulu Sea, Fiji Is.

Porcellana (Pisosoma) sculpta DE MAN 1888, p. 413-Java.

Pachycheles sculptus OrTMANN 1894, p. 29-Dar-es-Salaam, E. Africa.

........ ........ ORTMANN 1897, p. 294-No new record.

........ ........ DE MAN 1902, p. 701--Ternate, Moluccas.

Pachycheles (Pisosoma) sculptus BaLss 1913, p. 32-No new locality. 
Pisosoma sculptum ORTMANN 1892, p. 265-Amami-Ösima.

$$
\text { DE MAN 1896, p. 378-Atjeh, North Sumatra. }
$$

Miyake 1942 , p. 374, text-figs. 33-35-Palau Is.

Material examined: Isigaki I., Ryūkyū, 15 ô $\hat{o}, 9$ 우, 23 ovig. 우 우 (SENAHA and MASAKI); $8 \hat{o} \hat{o}, 11$ ovig. 우, May 20-25, 1940 (KAWAHARA and MiYAKE).

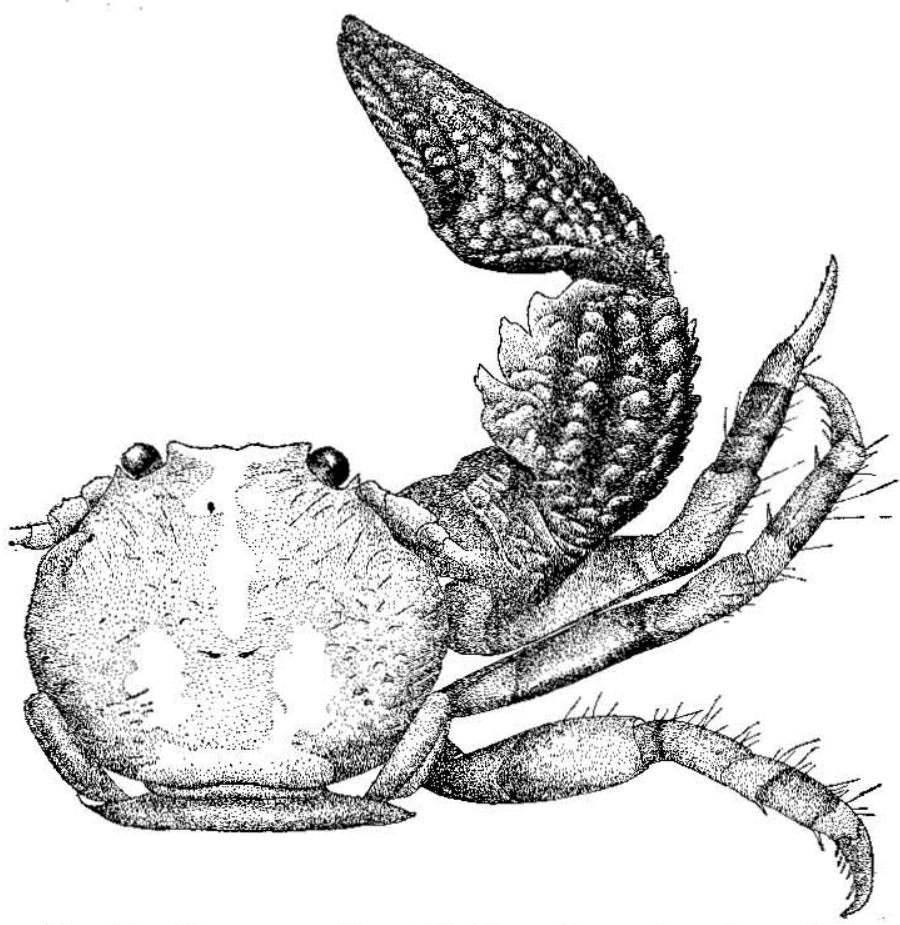

Fig. 37. Pisosoma sculptum (H. Mitne-Edwards), male, $\times 12$.

Dimensions (in $\mathrm{mm}$ ):

Length of carapace

Breadth of carapace

Length of wrist

Breadth of wrist

Length of palm

Breadth of palm

Length of movable finger

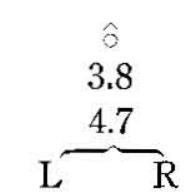

$2.2 \quad 3.0$

$\begin{array}{ll}2.0 & 2.2\end{array}$

$3.0 \quad 3.2$

$2.0 \quad 2.8$

$1.3 \quad 1.6$

\begin{tabular}{|c|c|c|c|}
\hline & & \multicolumn{2}{|c|}{ ovig. ? } \\
\hline & & & \\
\hline & & & \\
\hline$L^{\prime}$ & $\mathrm{R}$ & $\mathrm{L}$ & $\mathrm{R}$ \\
\hline 2.6 & 3.4 & 4.6 & 4.8 \\
\hline 2.2 & 2.4 & 2.9 & 4.0 \\
\hline 2.8 & 4.2 & 4.3 & 5.7 \\
\hline 2.9 & 3.6 & 3.2 & 4.6 \\
\hline 1.8 & 1.8 & 2.2 & 3.1 \\
\hline
\end{tabular}

ovig. ? 5.6 
Distribution: East Africa, Sumatra, Java, Fiji Is., Palau Is., Sulu Sea, Ryūkyū (present paper).

\section{Pisosoma pisum (H. Milne-Edwards) \\ Text-figs. $38-39$.}

Porcellana pisum H. MiLne-Edwards 1837, p. 254-China Sea (Typelocality).

........ ........ HELLER 1865, p. 73-Nicobars.

Pachycheles pisum ORTMANN 1897, p. 295-Thursday I.

........ ….... Rathbun 1924, p. 30-N. W. Australia.

........ ........ GoRdon 1935, p. 9-Eiland Enoe; New Guinea.

Pachycheles pulchellus Miers 1884, p. 273, P1. 30, fig. A-Torres Strait.

........ ........ HENDERSon 1888, p. 114-Flinder passage, Torres

Strait.

........ ORTMANN 1894, p. 30-Torres Strait.

........ ........ DE MAN 1902, p. 702-Ternate, Moluccas.

Pisosoma pisum DE MAN 1896, p. 380-Atjeh, N. Sumatra.

This species closely resembles $P$. sculptum in its outer appearance. In the forms of carapace, front, antennule, antenna, maxilliped, ambulatory legs, and in their ornamentation or armature, both these species agree strikingly.

This species, however, is distinguish-

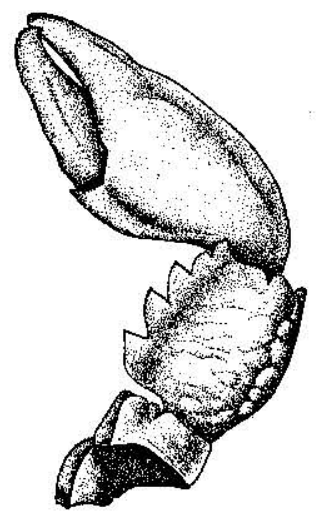

Fig. 38. Cheliped of Pisosoma pisum (H. Milne-Euwards), $\times 6$. ed at first sight by the ornamentation of the cheliped. Wrist slightly longer than broad, and armed with three or four acute teeth on anterior margin, its upper surface almost smooth, but somewhat uneven, presenting oblique elevations which pass into granules towards the posterior margin; palm bears three or four somewhat uneven longitudinal ridges, between which two or three longitudinal grooves are formed; the upper surface glabrous, but distinctly punctate.

Material examined: Isigaki I., Yaéyama-Group, Ryūkyū, 5 우 9,2 ovig. 우 May 23, 1940 (Kawahara and Miyake). 
Dimensions (in $\mathrm{mm}$ ):

Length of carapace

\begin{tabular}{|c|c|c|c|}
\hline & & & $\begin{array}{l}\text { g. } 9 \\
1.5 \\
.6\end{array}$ \\
\hline $\mathrm{L}$ & $R$ & $\mathrm{~L}$ & \\
\hline 2.4 & 2.8 & 3.0 & 3. \\
\hline 2.1 & 2.5 & 2.6 & 3. \\
\hline 3.2 & 4.0 & 4.0 & 4 \\
\hline 2.3 & 3.0 & 3.0 & 3 \\
\hline 2.1 & 2.9 & 2.9 & \\
\hline
\end{tabular}

Breadth of carapace

Length of wrist

Breadth of wrist

Length of palm

Breadth of palm

Length of movable finger

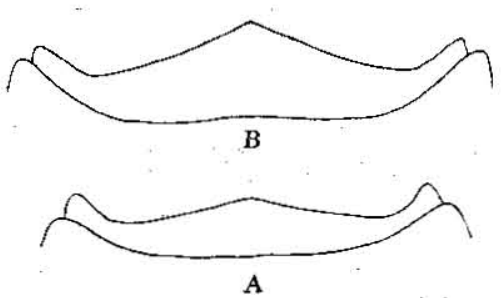

Fig. 39. Sternum of third maxilliped.

A Pisosoma sculptum, female, $\times 25$,
B Pisosoma pisum, ovigerous female, $\times 25$.

Distribution: Nicobars, Sumatra, New Guinea, North Australia, China Sea, Yaéyama-Group Ryūkyū.

\section{Pisosoma fronto (MELIN) New combination}

Text-figs. $40-41$.

Pachycheles fronto Melin 1939, p. 114, text-figs. 69-71-Ogasawara

Is. (Type-locality).

Carapace oval in outline, broader than long and in male broader than in female; upper surface punctate and sparsely hairy behind front; lateral portions glabrous with transverse ridges. Front without hairs and glabrous; frontal margin almost straight, slightly produced in the middle.

First peduncle of antennule broader than long; anterior margins undulated and toothless; ventral surface with three granulated lines, being margined with hairs. Antenna smooth, cylindrical; first peduncle provided with two protuberances on anterior margin 
and with hairs on outer margins; second peduncle granulated and much produced in the middle; third peduncle armed with one or two protuberances on the proximal part; third and fourth pedun-

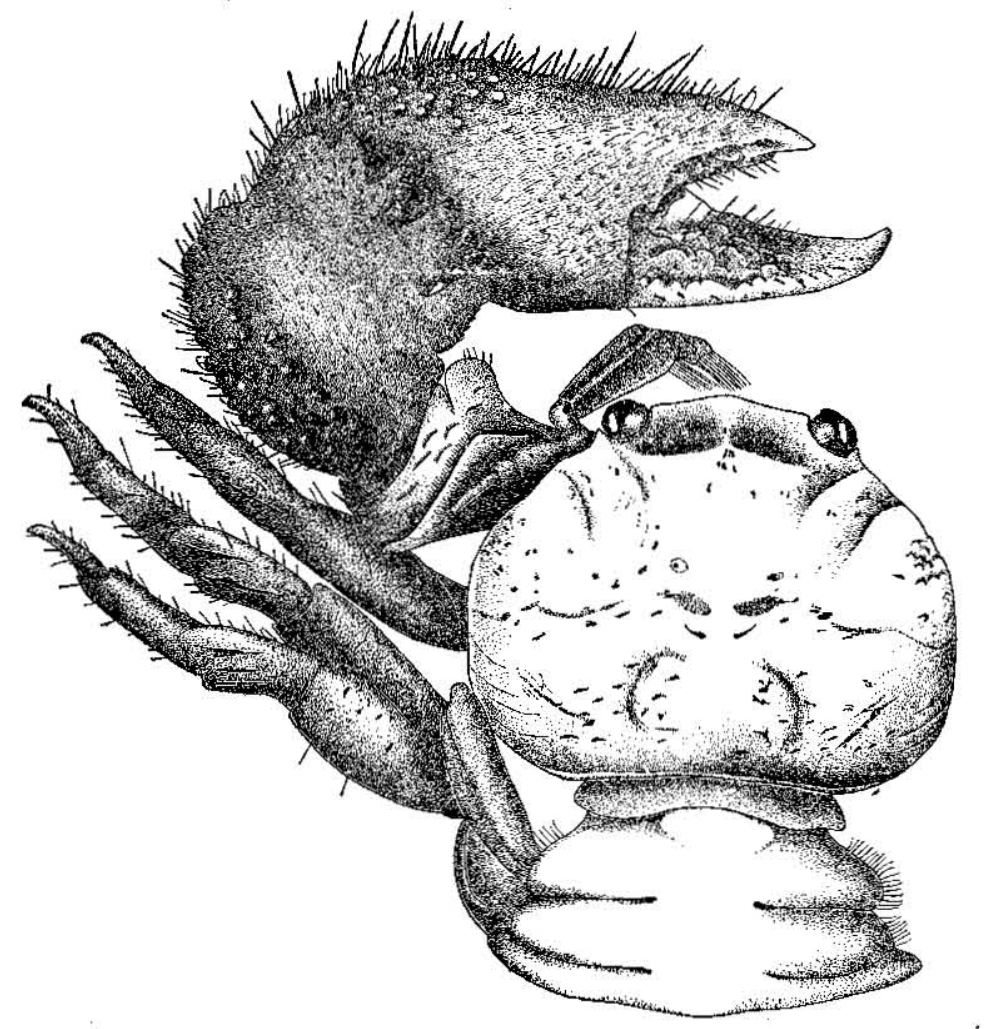

Fig. 40. Pisosoma fronto (MrLin), female, $\times 7.5$.

cles provided with some setae on upper surface. Their relative lengths are II : III : IV $=9: 12: 7$. Third maxilliped: Carpus smooth, and a little shorter than merus; merus furnished with short, transverse lines; the laminate crest of merus symmetrical, its inner and upper margins provided with rounded teeth. Sternum of third maxilliped: Central process very broad, antero-lateral margin almost straight; sinus of male deeper and more angular than that of female.

Chelipeds unequal; arm has a large lobe on the extremity; wrist armed with four saw-teeth on upper margin, the three prox- 
imal teeth almost equal in size, while distal one is rather small; upper surface of wrist covered with short setae on anterior half, but tuberculated on posterior half; palm covered with tubercles and short hairs on upper surface, its outer margin serrated posteriorly.

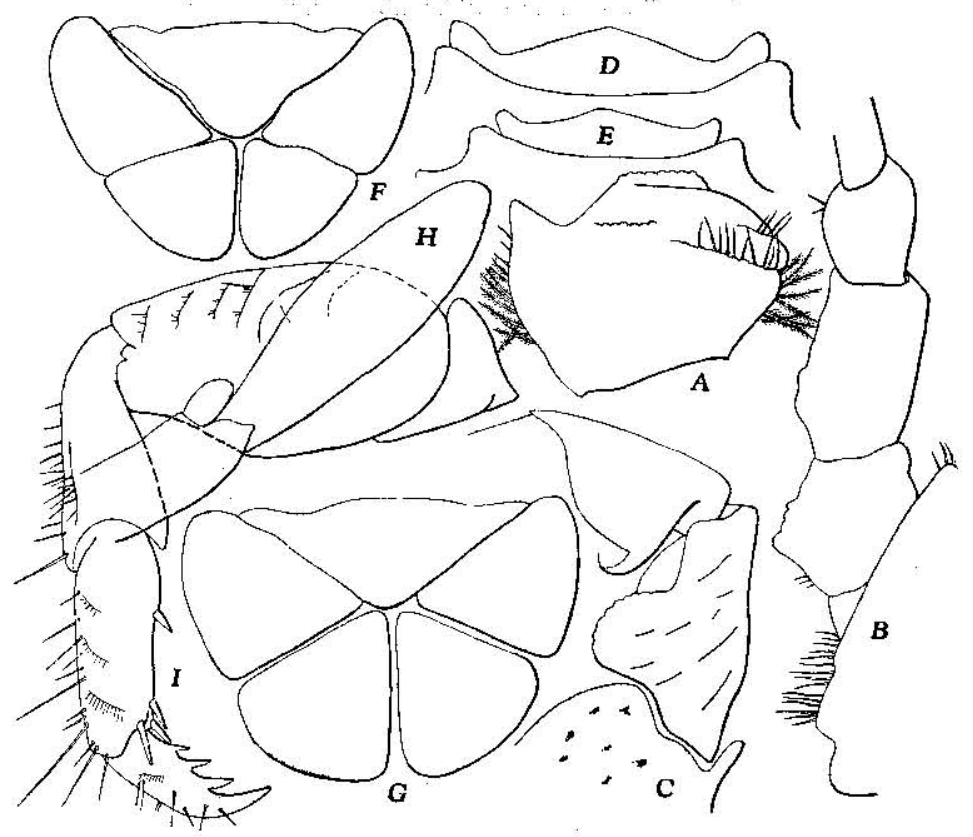

Fig. 41. Pisosoma fronto (MiLin).

A First peduncle of left antennule, ventral view, $\times 40, \quad$ B Basal peduncles of left antenna, ventral view, $\times 40, \quad \mathrm{C}$ Merus and carpus of third maxilliped, ventral view, $\times 25, \mathrm{D}$ Sternum of third maxilliped of male, $\times 25, \mathrm{E}$ Same of female, $\times 12, \mathrm{~F}$ Telson of abdomen of male, $\times 25, \quad G$ Same of female, $\times 12, \quad H$ Distal part of abdominal appendage, $\times 7.5, \quad$ I First ambulatory leg of left side, $\times 12$.

Ambulatory legs stout and hairy; carpus not armed with spinule at distal end of upper margin; propodus provided with four spinules; dactylus with three spinules besides the principal claw.

Telson of abdomen five-jointed, central plate very small.

Colour in life: Dorsal surface orange-yellow, ventral whitish.

Habitat: Found in coral reefs between tide-marks. 
Mcterial examined:

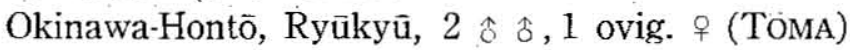

Isigaki I., Ryūkyū, many specimens (SEnAHA and MASAKI); $5 \preccurlyeq$, 6 ovig. क q , May 22, 1940 (Kawahara and MrYaKe).

Dimensions (in $\mathrm{mm}$ ):

1) Largest specimens of the collection.

Length of carapace

Breadth of carapace

Length of wrist

Breadth of wrist

Length of palm

Breadth of palm

Length of movable finger

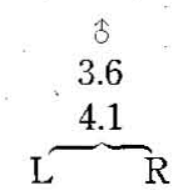

$2.7 \quad 3.5$

$2.0 \quad 2.0$

$3.0 \quad 4.0$

$2.3 \quad 3.2$

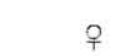

3.8

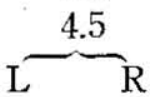

ovig. ㄱ.

$1.5 \quad 1.5$

4.7

$\mathrm{L}-\underbrace{5.8}_{\mathrm{R}}$

$4.1 \quad 3.8$

$3.3 \quad 2.4$

$4.8 \quad 3.6$

$3.8 \quad 2.7$

$2.6 \quad 1.8$

2) Mode of dimensions in the collection

Length of carapace

Breadth of carapace

Breadth of carapace

Length of carapace

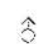

3.2

3.8

1.18
우

3.5

4.6

1.31 ovig. 우

4.0

5.0

1.25

Distribution: Ogasawara Is., Ryūkyū (present paper).

\section{Genus Porcellana LAMARCK restricted}

Porcellana Lamarck, Syst. des anim. sans vert., p. 153, 1801 (in part); H. Milne-Edwards 1837, p. 247 (in part); DE HAAN 1849, p. 199 (in part); DANA 1852, p. 410 (in part); STIMPSON 1858 , p. 66 ; 1907 , p. 187 ; Heller 1863 , p. 181; HASWELL 1882 , p. 147 (in part); HeNDERSON 1888, p. 109; MTYAKE 1942, p. 353.

Carapace usually convex, as broad as long, sometimes broader, suborbicular and depressed above; front prominent and dentate, the teeth usually well developed; eyes, of moderate size, the orbits deep; first peduncle of antenna large, projecting within in the form of a triangular tooth, and much produced outwards, far removing the second peduncle from orbit; its second peduncle 
cylindrical, not crested; second and third peduncles subequal in length; chelipeds variable in form, moderately flattened, wrist rather short, fingers often contorted; dactylus of ambulatory legs usually rather long and robust, terminating in a single claw, being sometimes short and armed with unguicles.

Type: Porcellana platycheles LAMARCK

The following five species have been reported in my previous paper (1942). 1. P. armata DANA, 2. P. suluensis DANA, 3. $P$. nitida Haswell, 4. P. murakamii MiYake, 5. P. melissa Mryake.

Key to the species of Porcellana

A) Carapace almost smooth, not areolated above. Eyes rather large

B) Dactylus of ambulatory leg rather short, and furnished with two or more unguicles

C) Dactylus furnished with two unguicles. Carapace armed with three lateral teeth. Wrist armed with three acuminate teeth on anterior margin .......................................... suluensis

CC) Dactylus furnished with three unguicles. Carapace armed with a single lateral tooth. Wrist toothless and provided with entire laminate crest throughout the margin...................... nitida

CCC) Dactylus furnished with two unguicles, proximal one of which more or less small; besides them there are two or three spinules

D) Wrist armed with three acuminate teeth on anterior margin. Dactylus with three spinules besides unguicles armata

DD) Carapace of entire lateral margin. Wrist armed with a single tooth on anterior margin. Dactylus with two spinules besides unguicles pulchra

BB) Dactylus of ambulatory leg of a normal form and provided with five spinules...................... serratifrons

AA) Carapace convex, areolated above. Eyes small. Palm of cheliped furnished with a line of stiff hair B) Carapace unarmed on the lateral margin...... murakamii 
BB) Carapace armed with minute teeth on the lateral margin

C) Cheliped and ambulatory legs rather broad. First antennular peduncle with acuminate spines on anterior margin................................ ornata

CC) Cheliped and ambulatory legs slender. First antennular peduncle granulated on anterior margin melissa

\section{Porcellana ornata STIMPSON}

Text-figs. $42-43$.

Porcellana ornata STIMPSON 1858, p. 242; 1907, p. 188-Hongkong (Type-locality). GORDON 1931, p. 529, figs. 1 A-D-Hongkong.

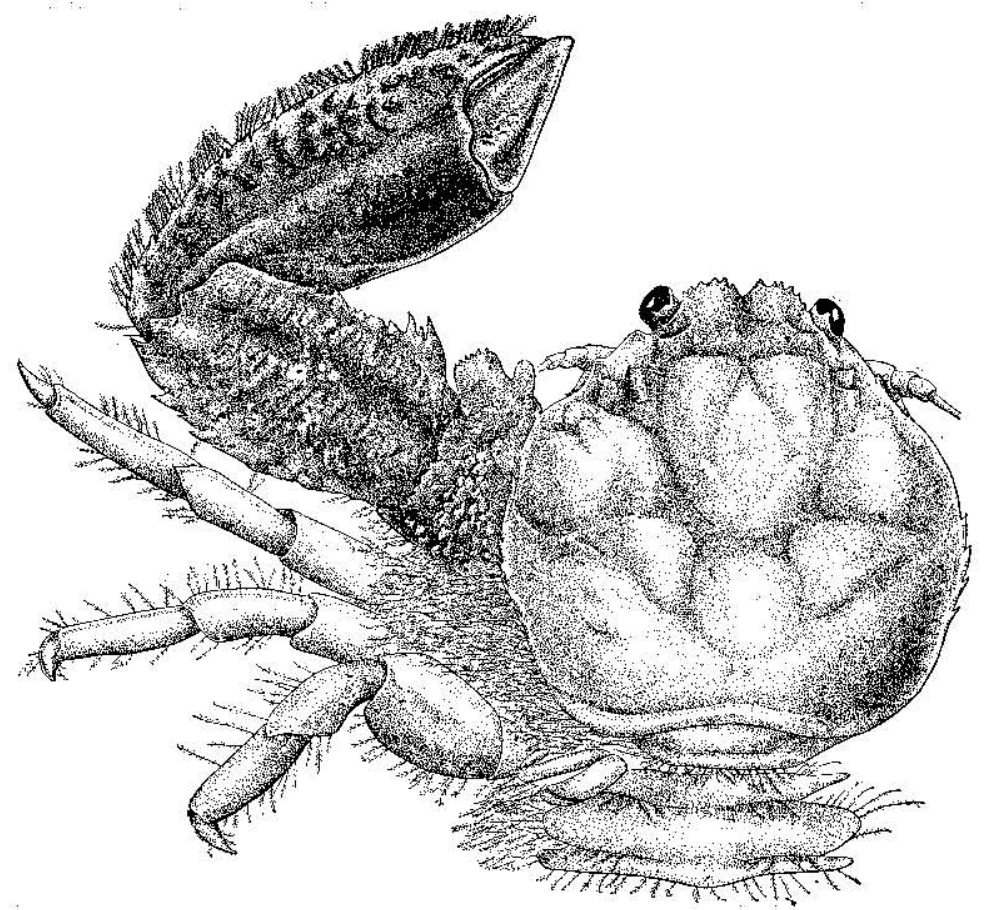

Fig. 42. Porcellana ornata Stimrson, ovigerous female, $\times 7.5$.

Carapace subovate, upper surface rather convex in both directions; regions areolated distinctly, protogastric and hepatic regions 
particularly prominent, epigastric region slightly elevated in front of protogastric which is divided into two lobes, outer lobe much smaller than inner one; mesogastric and urogastric regions fused into one lobe; cardiac region faintly distinct. Front divided into two lobes by a deep median sulcus, frontal margin minutely serrated; supraorbital margin provided with a prominent tooth above the eye. Lateral margin armed with two to six denticles on branchial region, and a small tooth produced in front of the outer protogastric lobe.

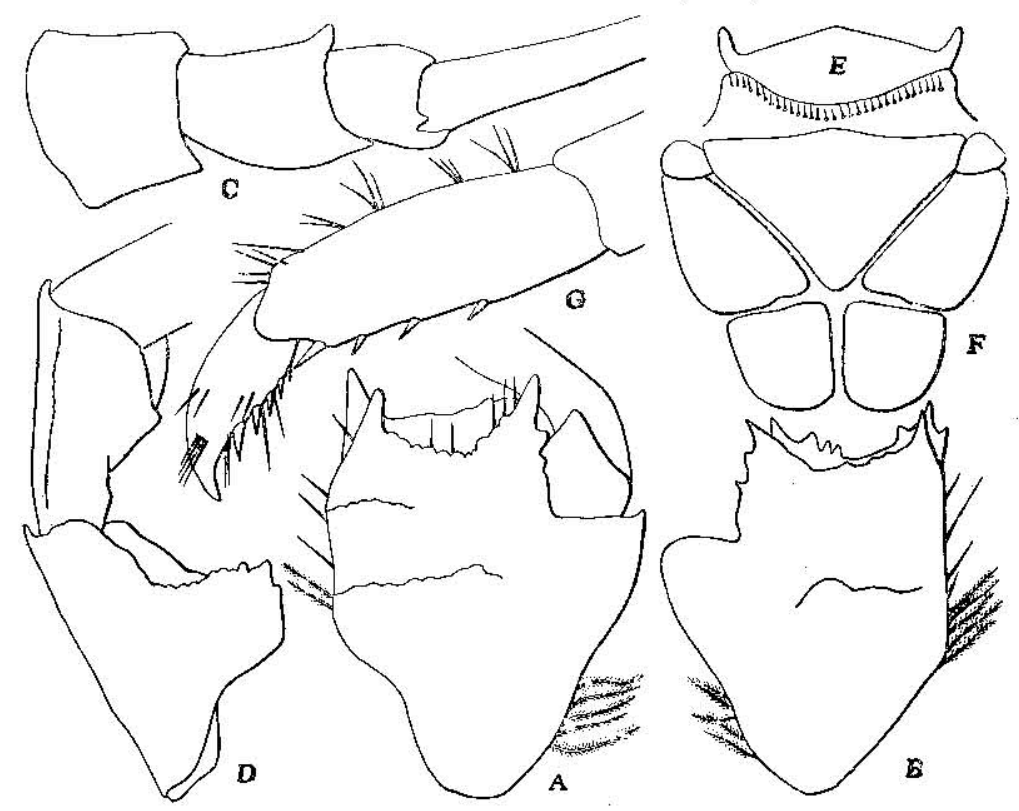

Fig. 43. Forcellana ornata STimrson.

A First peduncle of right antennule, ventral view, $\times 40, \quad B$ Same of another specimen left side, $\times 40$, C Basal peduncles of right antenna, dorsal view, $\times 40$, D Merus and carpus of third maxilliped of right side, ventral view, $\times 25, \mathrm{E}$ Sternum of third maxilliped of female, $\times 12$, F Telson of female, $\times 12, \quad G$ Dactylus and carpus of ambulatory leg, $\times 25$.

First peduncle of antennule smooth, much larger than broad, upper plate armed with four prominent teeth on each angle, sometimes one tooth wanting from the inner angle of dorsal side. 
Antenna smooth; second peduncle broader than long and divergent proximally; third peduncle a little divergent distally, the upper distal end much projecting into a lobe; fourth peduncle short. Their relative lengths are II $:$ III $:$ IV $=3: 3: 2$. Third maxilliped very smooth; the crest of merus subquadrate with its anterior margin undulated. The sternum of third maxilliped very short, its central process not so much produced as the lateral ones; margins almost straight; lateral process very slender and directed inwards; anterior margin of thoracic sternum strongly convex.

Chelipeds broad and rather flat, almost equal; upper surface sculptured with ridges and tubercles; arm has a large lobe on upper distal end; wrist oblong, quadrate, with two longitudinal ridges on upper surface, and with its anterior margin minutely serrated, sometimes straight and smooth, except at its inner extremity, where there is a small denticulated lobe; posterior margin of wrist dentate; palm very broad and flat, not twisted, with a rather prominent median ridge and acute, smooth, ciliated outer margin; fingers short, not gaping; dactylus a little longer than the other finger.

Ambulatory legs hairy; merus rather broad, its distal end of posterior margin unarmed; propodus armed with five or six spinules on posterior margin; dactylus with five spinules.

Telson of abdomen seven-jointed, central plate rather large, antero-lateral one very small, medio-lateral divergent posteriorly, postero-lateral rather large, being longer than broad.

Colour in life: Dorsal surface grayish white, ventral whitish; hairs brownish.

Habitat: Found under stones at low tide.

Material examined:

Tanabe Bay, Prov. Kii, 1 , in possession of the Seto Marine Biological Laboratory (UंTiNomi).

In'no-sima, Prov. Bingo, Inland Sea, 5 우, $1 \hat{\jmath}$, infested by Sacculina, deposited in the Onomiti Marine Biological Laboratory, July 7, 1917 (TAKI).

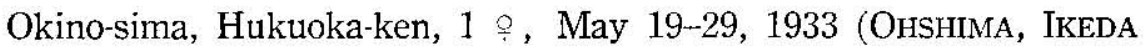
and YASUMOTO).

Tomioka, Amakusa, 3 ㅇ 우, Aug. 5, 1936 (BABA). 
Dimensions (in $\mathrm{mm}$ ):

$\begin{array}{lccc} & \hat{5} & \text { o } & \text { ovig. }+ \text { + } \\ \text { Length of carapace } & 6.0 & 4.0 & 6.0 \\ \text { Breadth of carapace } & 6.3 & 4.3 & 6.5\end{array}$

Distribution: Hongkong, Nippon: Tanabe Bay, Inland Sea, Okino-sima, Amakusa. This is the first record from Nippon.

\section{Porcellana serratifrons STIMPSON Text-figs. 44-45.}

Porcellana serratifrons STIMPSON 1858, p. 242; 1907, p. 189, Pl. 23, fig. 2--Hongkong (Type-locality).

............... DE MAN 1887, p. 417-Noorwachter I., Java.

........ ........ HENDERSON 1888, p. 110, Pl. 11, figs. 5, 5aHongkong, Arafura Sea.

China.
GORDON
1931,
p. 526-Hongkong; Pei-tai-ho,

Porcellana spinulifrons Miers 1879, p. 46-Strait of Tyōsen. GORDON 1931, p. 530, text-figs. 4-5-Hongkong.

Carapace slightly convex, nearly smooth, glabrous and anteriorly contracted, posteriorly broadly rounded and slightly striated towards the sides. Lateral margin acute, turning inwards a little on the surface of the carapace at the lateral notch. There is a small, sharp tooth at the middle of the lateral margin, and sometimes another smaller tooth in front of it on the antero-lateral margin; a spine over the insertion of the antenna, and another minute one just behind the external angle of the orbit. Front trilobed, lobes prominent, triangular; margins minutely serrated; middle lobe largest, but not much more produced than the others. Epimeral regions strongly striated.

The first peduncle of antennule longer than broad; lateral margins nearly straight, and almost parallel to each other, inner margin serrated distally and furnished with plumose hairs at the base; outer margin with thick hairs on anterior half; upper plate strongly concave, its margins armed with three or four teeth on each of four angles; the tooth of inner angle of ventral side subdivided into two or three spiniform teeth, ventral surface ornamented with a transverse line, which is margined with hairs. Antenna: First peduncle very broad, upper surface much de- 
pressed, with the extremity three-toothed; second peduncle rather short, provided with a small, acuminate tooth on upper distal end; third peduncle cylindrical, with two small teeth on upper margin;

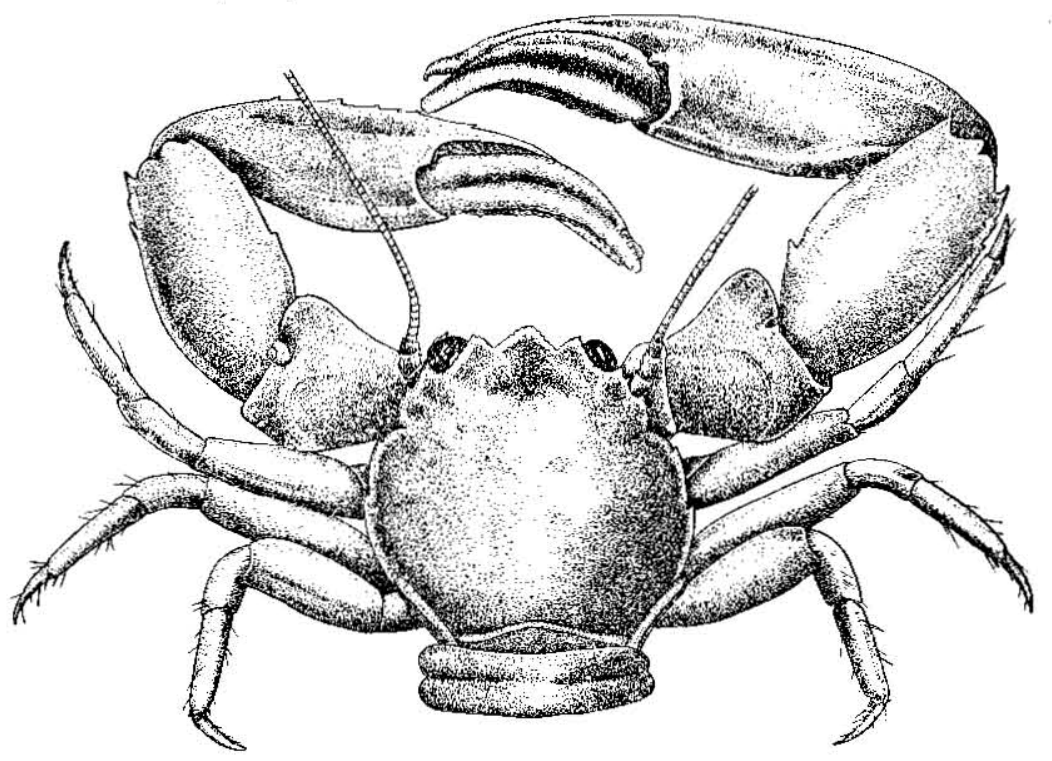

Fig. 44. Porcellana serratifrons STrMPson, male, $\times 5$.

fourth peduncle small, very short. Their relative lengths are II : III $:$ IV $=1: 2: 1$. Third maxilliped: The laminate crest of merus rounded, the margin of upper and outer angle somewhat undulated; carpus very much divergent distally, its distal margin strongly produced, and smooth, rounded. The sternum of third maxilliped very high, central process much projecting upwards, with its margin rounded, lateral process very small, separated by a large rounded sinus.

Chelipeds unequal in both sexes; angle at extremity of arm prominent, sometimes minutely bidentate; anterior margin of wrist armed with 3-5 teeth in smaller specimens, while there is only one tooth in larger specimen; the distal angle of anterior margin produced into an acute tooth, posterior margin armed with two or three spines on distal part; palm with a median angular ridge more or less prominent and obtuse; fingers twisted into nearly vertical plane, and pilose within. Smaller hand of young male 
less twisted than in adult; its outer margin spinulose; extremity of immovable finger deeply bifid; palm of female and smaller male specimens pubescent on outer margin and with its median ridge tuberculated or spinulated.

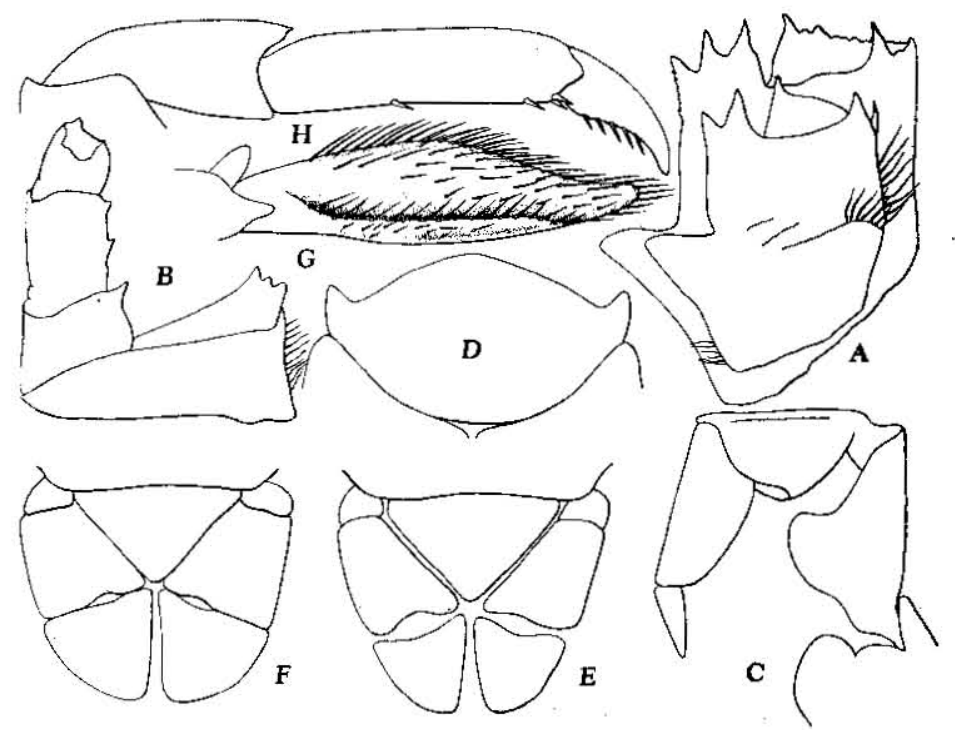

Fig. 45. Porcellana serratifrons STrmPson.

A First peduncles of left antennule, ventral view, $\times 20, \quad B$ Basal peduncles of left antenna, dorsal view, $\times 10, \quad \mathrm{C}$ Third maxiliped of left side, ventral view, $\times 10, \quad D$ Sternum of third maxilliped of male, $\times 10, \quad \mathrm{E}$ Telson of male, $\times 6, \quad \mathrm{~F}$ Same of female, $\times 6$, G Distal part of abdominal appendage, $\times 20, \mathrm{H}$ Second ambula. tory leg of right side, $\times 6$.

Ambulatory legs rather slender, hairy sparsely; carpus twothirds as long as propodus, propodus armed with four spinules on posterior margin; dactylus provided with five spinules on posterior margin.

Telson of abdomen seven-jointed; much broader in female than in male; distal joint of abdominal appendage spoon-shaped.

Colour in alcohol: Dorsal face yellowish-orange, ventral face whitish.

Habitat: Commonly found among fouling animals and seaweeds of ships' bottoms; sometimes living inside of dead shells between tide-marks. 
Material examined:

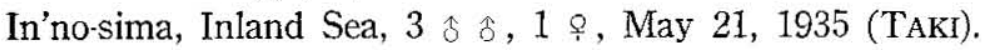

Bingo-Nada, 2 우 ㅇ, 1934 (TAKI).

Yanagawa, Ariake Bay, $1 \hat{0}, 2$ 우 우, found in dead shells, May 2, 1938 (MIYAKE).

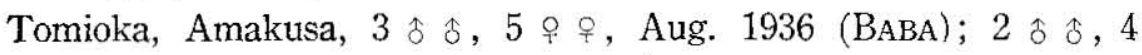

i 9 , attached to the bottom of a ship, Aug. 20, 1940 (MrYAKE).

Yusima, Amakusa, 2 상 ô, 2 우 우, July 3, 1937 (BABA).

Sasebo, rich materials from ships' bottoms (AKASI, NAKAo and MIYAKE).

Dimensions of the largest specimens in the collection (in $\mathrm{mm}$ ):

Length of carapace

Breadth of carapace

Length of wrist

Breadth of wrist

Length of palm

Breadth of palm

Length of movable finger
今

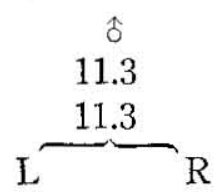

9.8

5.2

11.8

5.0

8.6 ovig. 우

7.8

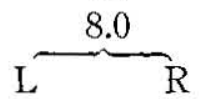

5.0

4.7

$2.8 \quad 3.0$

$6.7 \quad 5.1$

$3.2 \quad 2.9$

$3.2 \quad 3.0$

Distribution: Hongkong, Java, Arafura, Sea, Nippon: Inland Sea, Strait of Tyōsen, Ariake Bay, Amakusa.

\section{Porcellana pulchra STIMPSON}

Text-figs. 46-47.

Porcellana pulchra STIMPSON 1858, p. $243 ; 1907$, p. 192-Hongkong (Type-locality).

ORTMANN 1892, p. 268-Maizuru; Tanagava ( $=$ ? Yanagawa, Ariake Bay).

BaLss 1913, p. 31-No new locality.

............... GoRdon 1931, p. 526; p. 530, text-figs. 2-3-Peitai-ho, China.

Carapace rather convex laterally, smooth on the upper surface. Lateral margin regularly though slightly convex, expanded with a reflexed laminiform crest. Front very much projecting and laminiform, tridentate; median tooth much the largest, triangular, and 
acutely pointed; lateral teeth small, acute. External angle of the orbit acute, minutely serrated. Epimera somewhat concave.

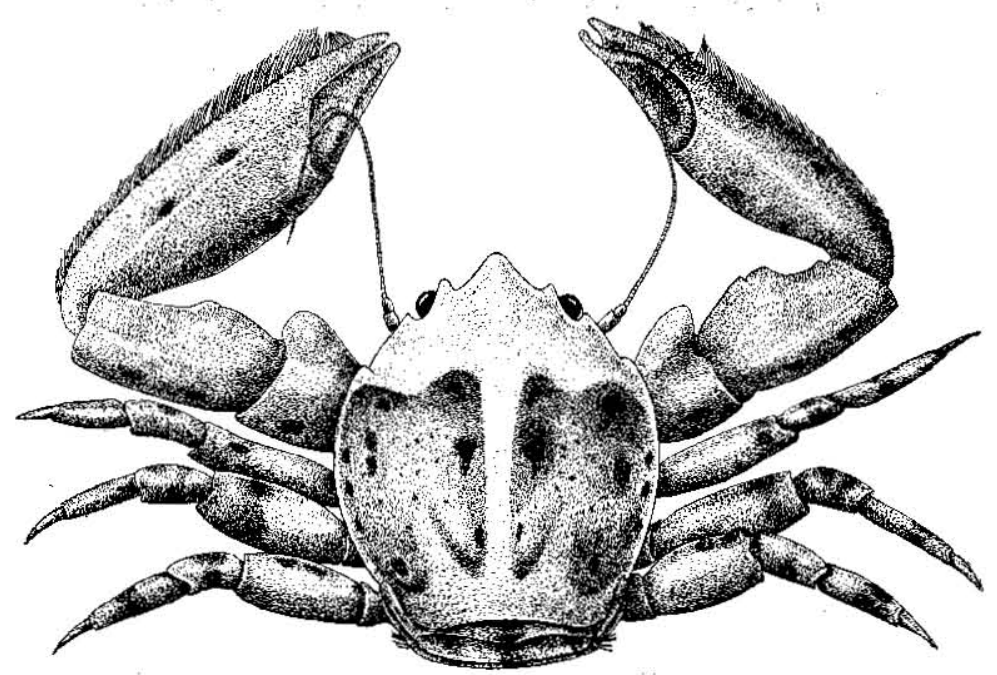

Fig. 46. Porcellana pulchra Stimsson, male, $\times 6$.

First peduncle of antennule longer than broad, its upper plate provided with three laminate teeth with apex rounded: the middle one stands on the dorsal side; the ventral surface with a transverse line, ornamented with hairs, the latero-exterior margin provided with a tuft of plumose hair on both distal and proximal sides, the latero-inferior margin also provided with similar hairs proximally. Antenna: First peduncle very much projecting outwards, with apex rounded; second peduncle slightly convergent distally, its upper margin provided with hairs; third peduncle cylidrical, but a little expanded near the distal margin; fourth peduncle small. Their relative lengths are II $: \mathrm{III}: \mathrm{IV}=5: 4: 3$. Third maxilliped: The laminate crest of merus asymmetrical, anterior margin almost straight, postero-lateral margin a little convex, its apex rounded; carpus almost smooth, its distal margin very much expanded. The sternum of third maxilliped trilobed, central process broad, rounded, and a little more projecting than the lateral ones.

Chelipeds rather small and slender; angle of arm rounded, very prominent; upper surface of wrist and palm with a median 
longitudinal ridge; a single tooth on the anterior margin of wrist; palm triangular, slender at base, its outer margin nearly straight, acute, and serrated beneath the marginal series of ciliae; posterior margin forming a ridge continuous with that of the movable finger.

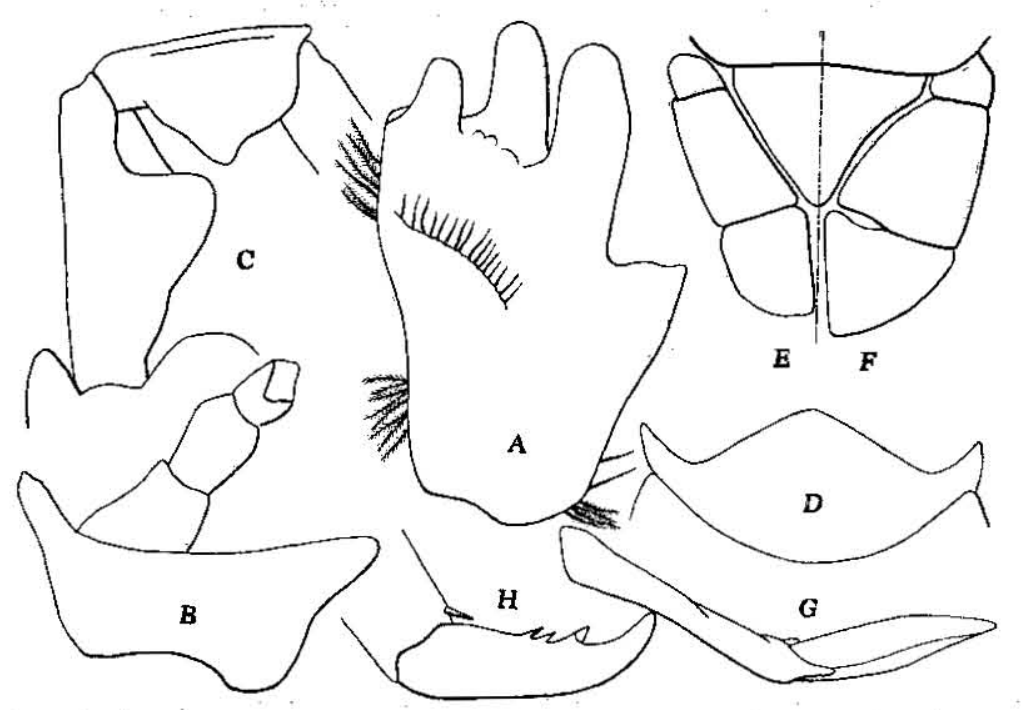

Fig. 47. Porcellana pulchra Stimrson.

A First peduncle of right antennule, ventral view, $\times 40, \quad$ B Basal peduncles of right antenna, dorsal view, $\times 25, \quad \mathrm{C}$. Merus and carpus of third maxilliped of right side, ventral view, $\times 25$, D Sternum of third maxilliped, $\times 25, \mathrm{E}$ Telson of male, $\times 12, \quad \mathrm{~F}$ Same of female, $\times 12$, G Abdominal appendage of male, $\times 25, \quad H$ Dactylus of ambulatory leg, $\times 25$.

Ambulatory legs sparsely provided with plumose setae; merus minutely serrulated above; posterior margin of propodus armed with a spinule at the distal end; dactylus provided with three or four spinules on posterior margin: the distal one largest.

Telson of abdomen seven-jointed; much broader in female than in male.

Colour in life: Front, of a light greenish-yellow colour; dorsal face of carapace bluish-brown, often with a greenish-yellow median line; legs clouded with a brownish colour, darkest at the middle of each segment. 
Habitat: Commonly associated with Pagurus haani (RATHBUN) and Scyphopatella walshi (REEve) ${ }^{1}$ inside of a dead shell.

Material examined:

Yanagawa, Ariake Bay, 5 今 $\hat{\circ}, 6$ ovig. 9 , May 2, 1938 (MrYAKE). Inland Sea: Bingo-Nada, 1 ovig. $q$, 1934 (TAKI).

Dimensions (in $\mathrm{mm}$ ):

$\begin{array}{lcc} & \text { s } & \text { ovig. } \\ \text { Length of carapace } & 7.0 & 5.5 \\ \text { Breadth of carapace } & 5.6 & 5.6\end{array}$

Distribution: Hongkong; Pei-tai-ho, China; Nippon: Maizuru, Inland Sea, Ariake Bay.

25. Porcellana armata DANA

Text-fig. 48.

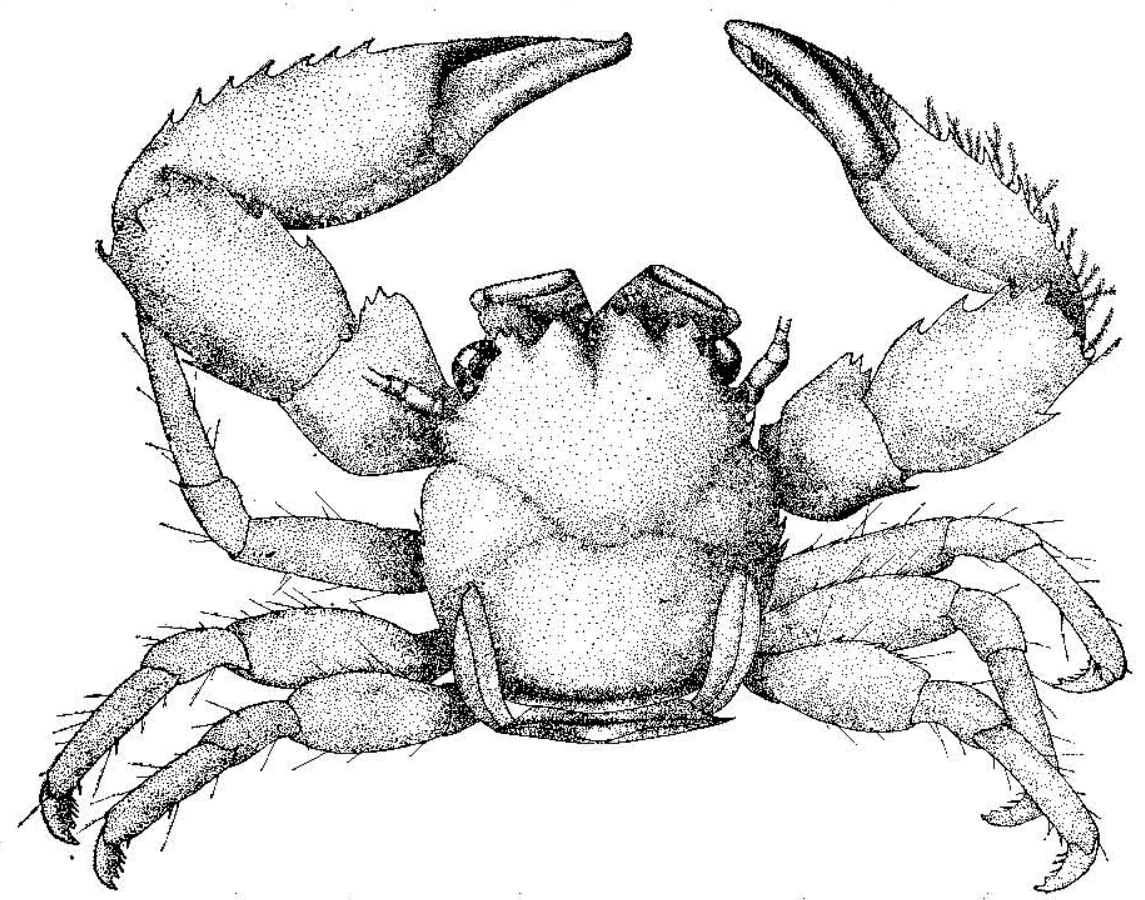

Fig. 48. Porcellana armata Dana, male, $\times 7.5$ (after Miyake).

1) According to the kind information by Mr. Tokubei Kuroda. 
Porcellana armata DANA 1852 , p. 426; 1855, Pl. 36, fig. 14 (as Porcellana spinuligera in the Plate)-Mangsi I., North Borneo (Type-locality).

.............. MiYAKe 1942, p. 356, text-figs. 17-19-Palau Is.

Porcellana latifrons StimPson 1858, p. 243; 1907, p. 190, Pl. 23,

fig. 4-Off Amami-Ōsima, Hongkong.

....... ........ DE MAN 1887, p. 415-Edam I., Java.

............... BaLSS 1913, p. 31-No new record.

............... Rathbun 1924, p. 31-N. W. Australia.

Distribution: North Borneo, Java, Palau Is., N. W. Australia, Hongkong, Off Amami-Ōsima.

26. Porcellana suluensis DANA

Text-fig. 49.
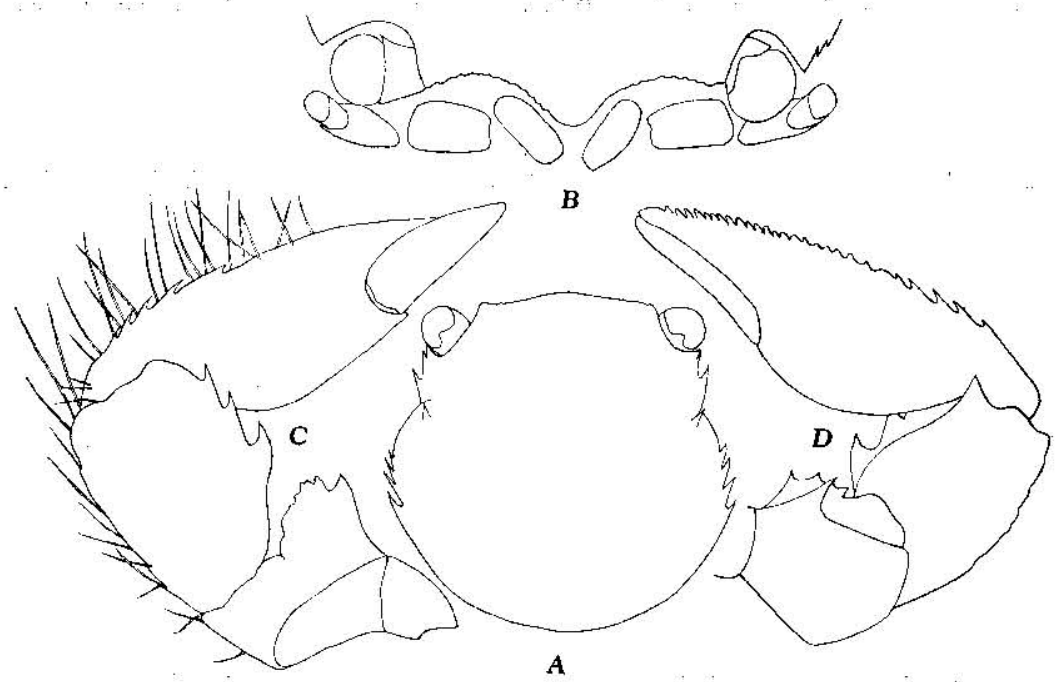

Fig. 49. Porcellana suluensis DaNA, female.

A Dorsal view of carapace, $\times 10, \quad$ B Front of carapace, $\times 16, \quad$ C Dorsal view of left cheliped, $\times 16, \quad \mathrm{D}$ Ventral view of same, $\times 16$ (after Mryake).

Porcellana suluensis DANA 1852, p. 414 ; 1855, Pl. 26, fig. 4-Sulu Sea (Type-locality).

Rathbun 1924, p. 30, Pl. 1., figs. 15-16-Northwestern Australia.

GoRdon 1935, p. 9, text-fig. 4-Eiland Enoe. 
........ ....... MrYạk 1942, p. 354, text-figs. 15-16-Palau Is.

Distribution: N. W. Australia, Eiland Enoe, Sulu Sea, Palau Is.

27. Porcellana nitida HASwELL

Text-fig. 50 .

Porcellana nitida Haswell 1882, p. 148-Port Denison, Queensland, Australia (Type-locality).

......... ....... MrYAKe 1942, p. 359, text-figs. 20-22-Palau Is.

Distribution: Queensland, Australia; Palau Is.

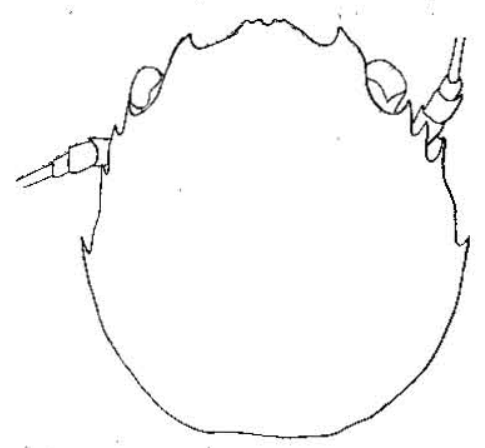

Fig. 50. Porcellana nitida Haswell.

Outline of carapace of male, $\times 7.5$ (after Mryake).

\section{Porcellana murakamii MrYAKE \\ Text-fig. 51.}

Porcellana murakamii MrYAKE 1942, p. 362, P1. 1, fig. 3; text-figs. 23-24-Palau Is. (Type-lacality).

Carapace longer than broad, subovate, rather convex, dorsal surface strongly areolated. Lateral margins entire, not dentate, expanded with a reflexed laminiform crest and separated from branchial regions by a deep groove. Front with a small median triangular lobe with apex concave strongly; frontal margin almost smooth, not serrated or denticulated.

First peduncle of antennule broader than long, anterior margin more or less undulated, projecting two or three lobes of irregular forms. Ventral surface smooth. First peduncle of antenna large, triangular, much produced beyond the upper margin of the carapace. Succeeding peduncles cylindrical, of which the third 
one projects upwards on the upper distal end as in the genus Petrolisthes. The relative lengths of basal peduncles are II:III: IV $=6: 7: 5$. Third maxilliped smooth on the ventral surface. The crest of merus much projecting inwards with rounded margins. The upper inner angle much curved in a convexed line.

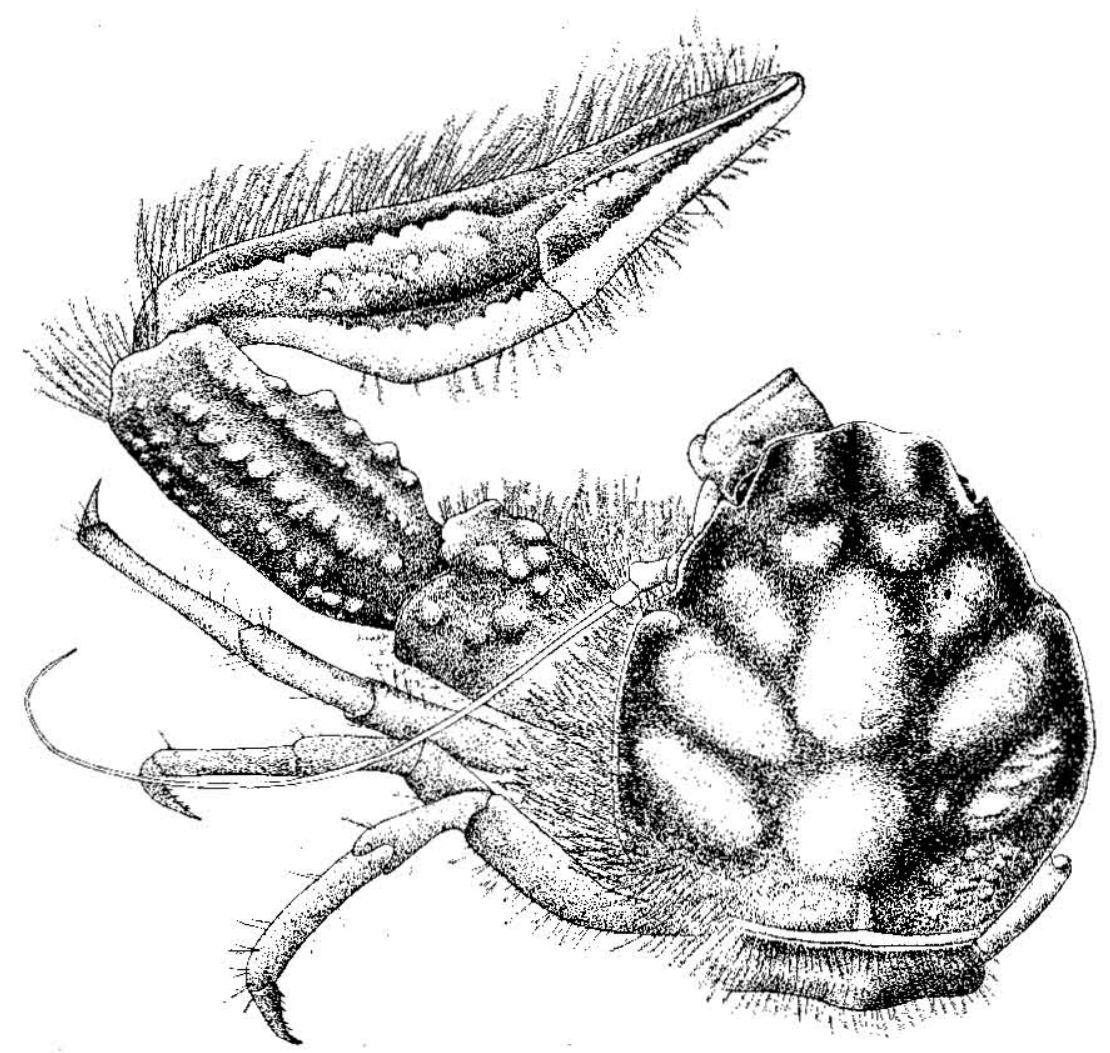

Fig. 51. Porcellana murakamii Mryakl, male, $\times 10$ (after Mryake).

Chelipeds unequal, the right one being larger in holotype; sculptured above with ridges, and somewhat irregularly tuberculated. Wrist oblong, quadrate, three longitudinal granulated ridges on its surface, and the anterior margin tuberculated, posterior margin straight. Palm broad and flat, with a rather prominent median ridge and an acute, denticulated, ciliated outer margin. Inner margins of fingers not dentate, with a little gap between them. 
Ambulatory legs rather slender, cylindrical, somewhat hairy. Meri smooth, unarmed. Propodi as a rule furnished with three spinules on the posterior margin: two of them at the distal end in pair, the other in front of them along the longitudinal axis. Dactyli rather long, usually furnished with four spinules along the posterior margin.

\section{Porcellana melissa MIYAKE}

Text-fig. 52.

Porcellana melissa Mryake 1942, p. 364, Pl. 1, fig. 4; text-figs. 2527-Palau Is.

Carapace subovate, as long as broad in holotype ( $q$ ), but a little longer than broad in cotypes (ovig. 우 \&). Upper surface areolated, protogastric, mesogastric, urogastric and branchial regions distinct. Urogastric and branchial regions covered with granules above. Front distinctly separated from supraorbital lobes by a notch. Median lobe of the front much deflexed downwards, forming a V-shaped notch between lateral lobes when seen from above. Frontal margins almost smooth, but serrated microscopically. Lateral margins of carapace furnished with two or three teeth at the middle; three in holotype. Orbit deep; eyes small.

First peduncle of antennule longer than broad. Upper surface furnished with two or three crest-like ridges and ornamented with granules in holotype, but cotypes lack such ridges on the upper surface. Ventral surface smooth. First peduncle of antenna large, its triangular teeth much produced under the eyes. Succeeding peduncles cylindrical, smooth in holotype, but more or less granulated in cotypes. In cotypes ventral surface of carpus granulated besides having a longitudinal line. Their relative lengths are II : III $: \mathrm{IV}=4: 5: 3$. Merus of third maxilliped longer than broad, smooth on the ventral surface. Laminate crest of merus on inner margin rather small, its anterior margin more or less undulated. Carpus also longer than broad.

Chelipeds subequal, left one being slightly larger. Arm smooth, very short, furnished with an obtuse tooth on the upper distal angle. Wrist quadrate, oblong; its breadth a little more than half the length and its length slightly larger than half the length or breadth of carapace. Upper surface ornamented with 
two longitudinal granulated ridges. Wrist of holotype armed with two obtuse teeth proximally on the anterior margin; proximal one rather broad, subdivided; in cotypes it is armed with two minute, acuminate teeth as in Porcellana ornata. Posterior margin of wrist

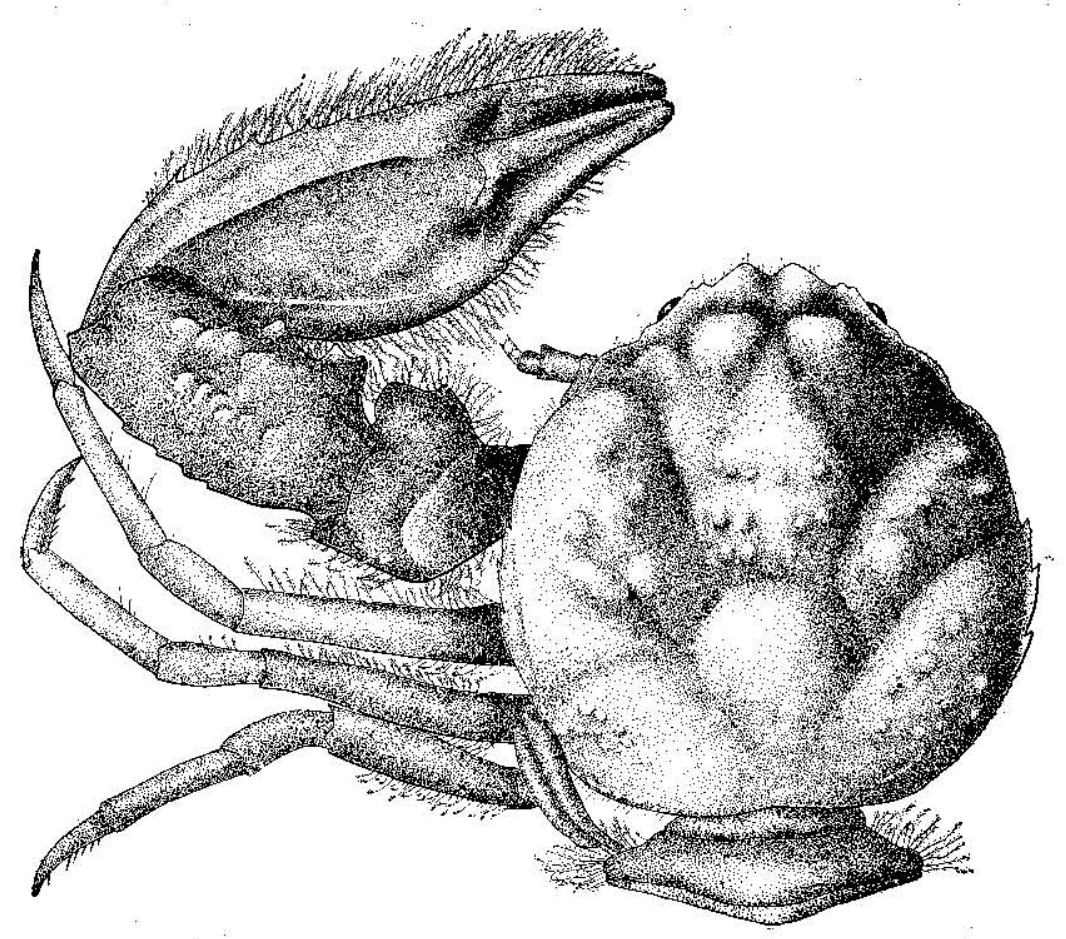

Fig. 52. Porcellana melissa Miyakr, female, $\times 7.5$ (after Mryake).

denticulated. Palm broad, flat, smooth on upper surface; median ridge on the upper surface rather prominent and straight; outer margin armed with many minute teeth beneath the feather-like hairs: three or four teeth on proximal ends somewhat larger. There is no gap between fingers.

Ambulatory legs rather slender, meri ornamented with short hairs closely. Propodi usually armed with three spinules on the posterior margin: two of them stand at the distal end in pair, the other in front of them. Dactyli rather long, armed with five spinules which increase in size distally. 


\section{Genus Porcellanella WhITE}

Porcellanella White 1852, p. 395 (sine descr.); STIMPson 1858, p. $243 ; 1907$, p. 192 ; HASWELL 1882, p. 149 ; HENDERSON 1888, p. 112; MiYAKE 1942, p. 368.

Carapace oblong, very much longer than broad, with lateral margins almost parallel. Upper surface of carapace smooth, polished, with peculiarly coloured markings, not areolate even in anterior regions. Eyes small. Front prominent, composed of three flattened horizontal teeth. First peduncle of antennule longer than broad. First peduncle of antenna elongated as in Porcellana. Chlipeds smooth, unarmed, with wrist short and palm strongly elongated. Ambulatory legs with merus robust and dactylus short, compressed and multiunguiculate.

\section{Type: Porcellanella triloba WHITE}

Members of the genus are known as commensal inhabitants. They are commonly found hiding themselves between the leaves of Pennatula. The distribution of the genus extends from Nippon, China Sea, Indian Ocean, farther eastwards as far as N. E. Australia, in waters of moderate depth. Only two species have hitherto been reported.

Key to the species of Porcellanella

A) Carapace very long, the proportion of length to breadth being 1.5:1. Apex of frontal lobes rounded. First peduncle of antennule convergent distally, provided with four or five close-set teeth. Dactylus of ambulatory leg armed with four unguicles, that of the penultimate one largest

triloba.

AA) Carapace not very long, the proportion of length to breadth being $1.22 \sim 1.3: 1$. Frontal lobes acuminate with apex pointed. First peduncle of antennule slightly divergent, provided with four spines on each anterior angle. Dactylus armed with four unguicles, that of third one largest .................................................. picta. 
30. Eorcellanellastriloba WHITE

Text-fig. 53.

Porcellanella triloba WHite, MacGILLIVRaÝ's voyage of H.M.S. "Rattlesnake"; vol. 2, 1852, Appendix, p. 394, Pl. 5, fig. 2N. Australia (Type-locality).

HASWEll 1882, p. 149-Cape Capricorn, Australia. Henderson 1893, p. 429-Rameswaram I., S.E.

India. ZeHNTNer 1894, p. 188, Pl. 8, fig. 17-Amboina. MiYaKe 1942, p. 368, text-figs. 28-29-Palau Is.

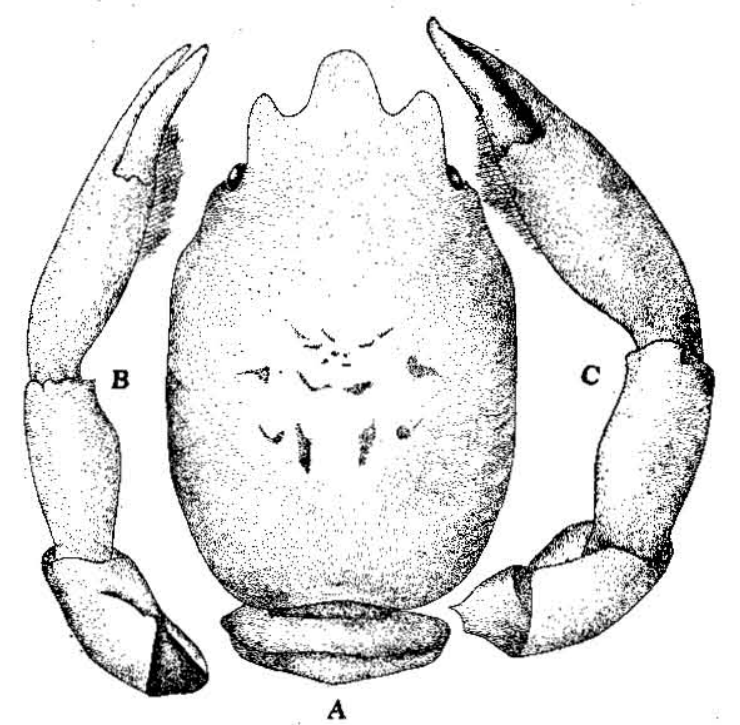

Fig. 53. Porcelanella triloba Whits, male, $\times 6$.
A Outline of carapace, B Left cheliped,
C Right cheliped (after MrчикE).

31. Porcellanella picta Stimpson

Text-figs. $54-55$.

Porcellanella picta StIMPson 1858, p. 243; 1907, p. 193, Pl. 22, fig. 6--Hongkong.

Porcellana (Porcellanella) picta DE MAN 1888, p. 220-King Island Bay, Mergui Is.

Porcellanella picta Yokoya 1933, p. 70-Toba, Ise Bay. 
Carapace oblong, depressed, longer than broad, the proportion of length to breadth being 1.22-1.3:1; upper surface smooth and even, glabrous, faintly striated anteriorly and on the sides. Lateral

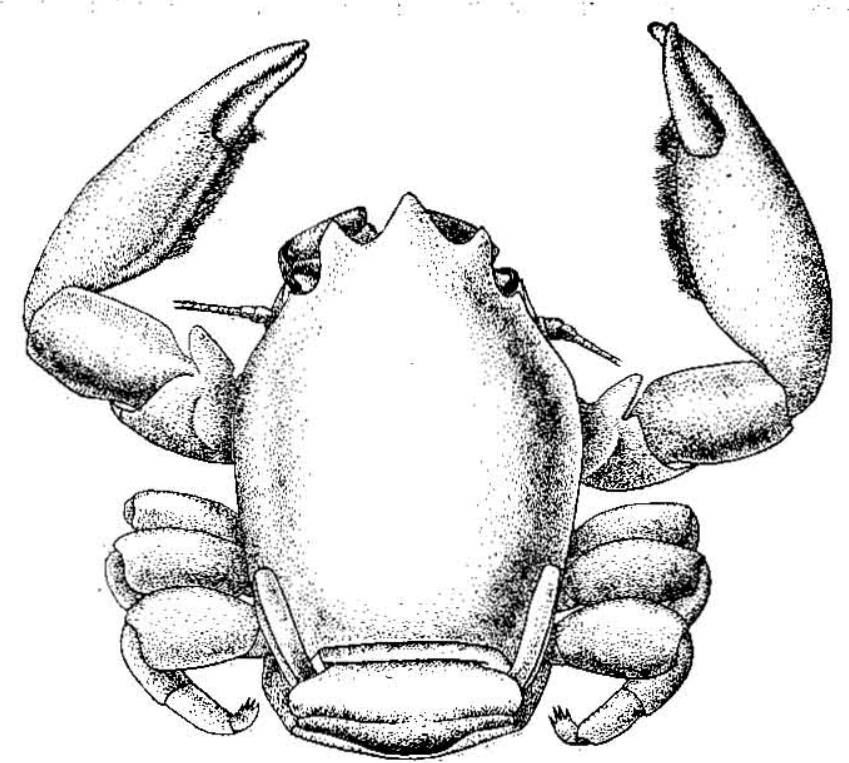

Fig. 54. Porcellanella picta Stimrson, male, $\times 4.5$.

margin scarcely acute, but distinct, with the epimeral suture running close beneath it. Front laminiform, tridentate; teeth acute: median tooth triangular and much larger and more projecting than the lateral ones; surface of front transversely striated.

First prduncle of antennule longer than broad, anterior plate much prolonged into acute tooth on each angle, so that four spines are visible from ventral side but sometimes without spine on outer two angles; anterior and exterior margins furnished with long hairs; ventral surface smooth, and with a line of hairs. Antenna cylindrical, glabrous; first peduncle very much larger, relative lengths of basal peduncles are II $: \mathrm{III}: \mathrm{IV}=5: 4: 3$. Third maxilliped smooth, striated; ischium very much projecting at the outer extremity, the laminate crest of merus asymmetrical, postero-lateral margin very long, with apex rounded; carpus triangular, divergent distally. Sternum of third maxilliped thick, central process strongly rounded, much larger than lateral ones. 
Chelipeds rather slender, sufficiently thick, somewhat rounded, smooth and glossy like the carapace; anterior angles of ischium and arm produced, acute; wrist small, with smooth margins; palm clongated, contracted at base, and ornamented within by a line of pubescence which extends longitudinally from the base of the fingers to the middle of the palm; fingers slender, tapering and irregularly curved, as if distorted; movable finger of larger hand much shorter than the immovable finger.

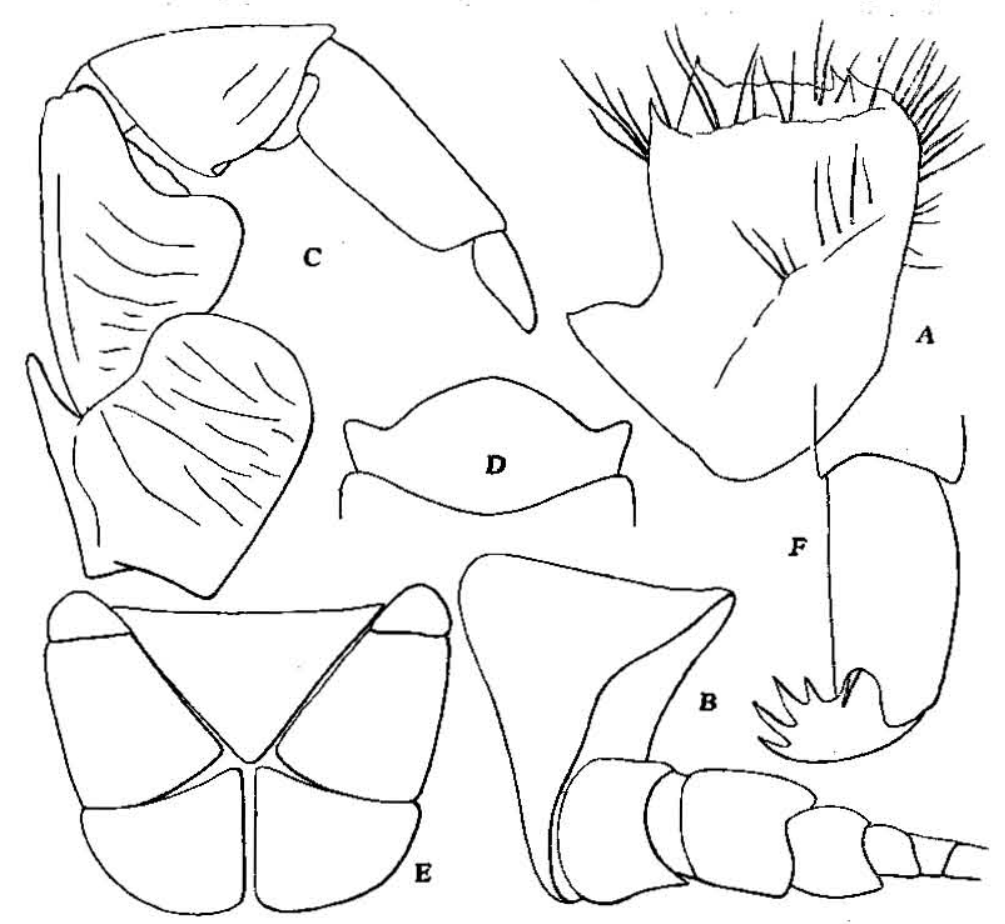

Fig. 55. Porcellanella picta Stimpson.

A First peduncle of left antennule, ventral view, $\times 25, \quad$ B Basal peduncles of left antenna, ventral view, $\times 25, \mathrm{C}$ Third maxilliped of right side, ventral view, $\times 15$, D Sternum of third maxilliped, $\times 12$, E Telson of male, $\times 12, \quad F$ Distal part of ambulatory leg, $\times 15$.

Ambulatory legs small, smooth, glossy, almost naked; merus oval, unarmed; propodus provided with a single spinule at distal end of posterior margin; dactylus armed with four sharp unguicles: proximal one a little smaller than distal one, next one largest. 
Telson of abdomen seven-jointed; central plate small, lateral plates very large.

Relationship: The carapace of $P$. picta is broader than that of $P$. triloba. In $P$. triloba, anterior angles of ischium and arm not produced. In other characters, it is distinguished from P. triloba WHITE by the structures of frontal teeth and first peduncles of antennule, and by spinulation of dactylus. HENDERSON and DE MAN have suggested that these two species may be united, but I cannot agree with their suggestion.

Colour in life is white, with a few large, blue, marginated spots or ocelli on the hands and the anterior portion of carapace (STIMPSON).

Colour in alcohol: Completely white.

Habitat: Commonly found living in leaves of Pteroeides chinense at 10-30 fathoms in Tanabe Bay.

Material examined:

Inland Sea: Bingo-Nada, $1 \hat{o}$, from Pteroeides, 1934 (TAKI).

Tosa, $1 \hat{\jmath}$, Oct. 17, 1941 (IsIKawa).

Tomioka, Amakusa, 1ㅎ․ Aug. 24, 1942 (Murakami).

Dimensions (in $\mathrm{mm}$ ):

P. picta

$\hat{\delta}$ (Inland Sea)

Length of carapace including frontal lobe

Breadth of carapace

Length of wrist

Breadth of wrist

Length of palm

Breadth of palm

Length of movable finger

\section{0}

3.5

8.9

4.9

4.5

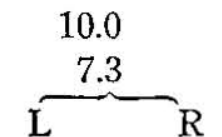

P. triloba

o (Palau Is.)

Distribution: Mergui Is., Hongkong; Nippon: Ise Bay, Tanabe Bay, Tosa, Inland Sea, Amakusa.

\section{Genus Polyonyx Stimpson}

Polyonyx STIMPSON 1858; p. 114 ; 1907, p. 194 ; Henderson 1888, p. 114 ; Shen 1936, p. 275; MiYake 1942, p. 370. 
Carapace suborbicular, broader than long, convex and smooth. Lateral margins strongly convex. Front rather narrow, much deflexed downwards, with an almost straight margin. First peduncle of antennule not toothed, but flattened or truncate at the anterior margin. First pednucle of antenna very broad, elongated and smooth. Chelipeds subequal, smooth, polished. Wrist very large, usually without teeth, but with a sharp entire internal crest. Palm with or without feather-like hairs. Fingers of smaller cheliped sometimes twisted into a vertical plane. Dactyli of ambulatory legs furnished with two or more unguicles.

Type: Polyonyx macrocheles (GIBBS)

Members of the genus are known to live commensally in the tubes of annelid worms, sometimes free-living. It is widely distributed from the east coast of North America, Australia, China Sea, Southern Nippon, Malay Archipelago, Indian Ocean and farther westwards as far as the Red Sea.

Key to the species of Polyonyx

A) Palm without a line of stiff hairs on outer margin .......

AA) Palm with a lines of stiff hairs on outer margin

biunguiculatus.

B) Wrist with one or two teeth on anterior margin ...

BB) Wrist furnished with a crest along anterior margin

C) The crest of wrist swollen at the middle; propodus armed with four spinules ............... sinensis.

CC) The crest of wrist not produced, having a straight free margin; propodus armed with three spinules ................................... utinomii.

\section{Polyonyx sinensis STIMPSON}

Text-figs. $56-57$.

Polyonyx sinensis Stimpson 1858, p. 244; 1907, p. 194, Pl. 19, fig. 5 -China Sea. (Type-locality).

Carapace convex, of a subquadrate form, with the corners rounded; the proportion of length to breadth being $3: 4$; upper surface smooth, glabrous to the naked eyes, transverse lineolate to magnifying lens near the margins. Front rather broad, measur- 
ing one-third as long as the breadth of carapace; it presents a much deflexed median lobe, which projects a little more forwards and downwards than lateral lobes. Orbits comparatively large, eyes concealed whithin them.

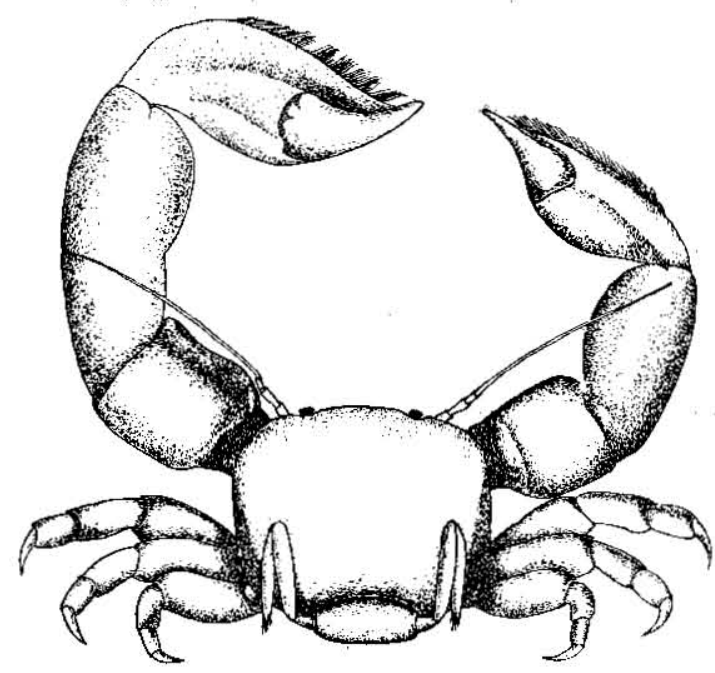

Fig. 56. Polyonyx sinensis Strmison, male, $\times 5.3$.

First peduncle of antennule of similar structure of other members of the genus; antero-inner lobe a little more produced than the upper plate. Relative lengths of basal peduncles of antenna are II $: \mathrm{III}: \mathrm{IV}=7: 10: 5$. The crest of merus of third maxilliped rather small, symmetrical and rounded. Sternum of third maxilliped slightly shorter than three-fourths as long as the anterior margin of thoracic sternum, with anterior margin almost straight; outer margin of the lateral process strongly rounded.

Chelipeds very unequal, smooth and glabrous; arm of larger one robust; convex above, upper distal angle distinct, but not produced; wrist much elongated, longer than palm and almost equal to the breadth of carapace, with its anterior margin expanded into a laminiform dilatation, broadest towards the palm; palm very thick, but much depressed towards outer margin which is lined with stiff hairs, extending almost to tip of the immovable finger. Fingers much twisted, with a gap between them; immovable finger armed with a tooth at the base of inner margin; 
- movable finger swollen basally, provided with a blunt tooth at the base. In smaller cheliped, merus, wrist and palm are almost similar in shape to those of the larger one. Fingers furnished with fine teeth along their inner margins, not gaping; tips pointed and slightly curved inwards toward each other.

Ambulatory legs smooth, slightly hairy; merus and carpus unarmed; propodi of first three pairs armed with two spinules along the longitudinal axis and two similar ones at distal ends of their posterior margins; dactylus terminates in an acute claw, in addition to it there are two smaller claws upon the principal claw, posterior margin of dactylus armed with two spinules. Telson of abdomen seven-jointed; central plate broader than long.

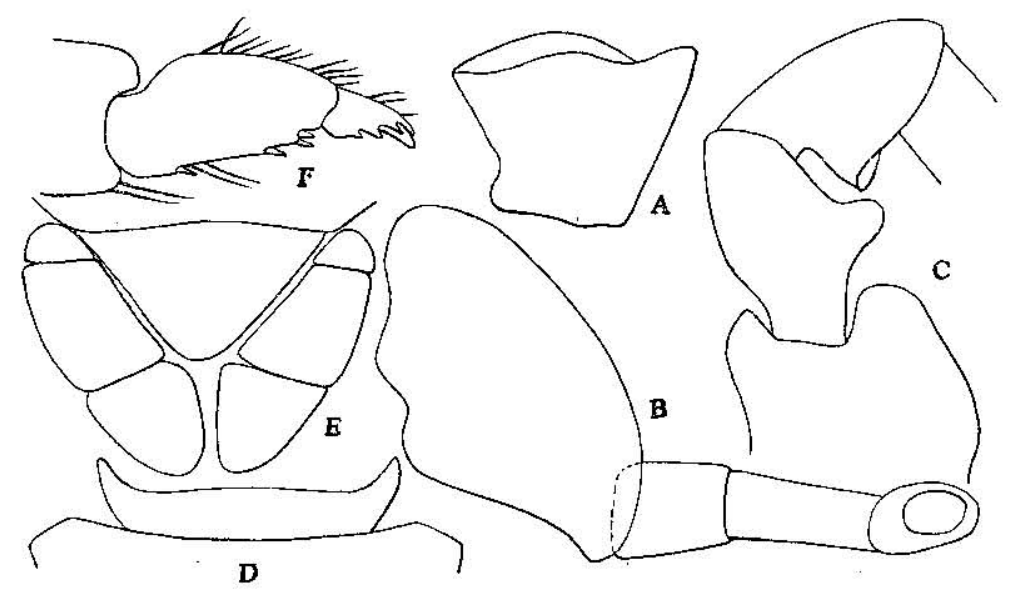

Fig. 57. Polyonyx sinensis Strmpson.

A First peduncle of right antennule, ventral view, $\times 40, \quad B$ Basal peduncles of left antenna, ventral view, $\times 40, \quad \mathrm{C}$ Merus and carpus of third maxilliped of right side, ventral view, $\times 40, \quad \mathrm{D}$ Sternum of third maxilliped, $\times 25, \quad$ E Telson of male, $\times 25, \quad F$ Dactylus and propodus of second ambulatory leg, $\times 25$.

Colour in life: According to Strmpson, "In life this species is of a clear, pale bluish-gray color, with large spots of a neutral tint or sepia color."

The markings and colour of the body turn pale and fade into whitish in alcohol. 
Habitat: Dredged from a bottom of shelly sand at twenty-six fathoms, in the China Sea, under the twenty-third parallel of north latitude (STIMPSON).

Material examined: Tomioka, Amakusa ; 1 s , Jul. 10, 1934 (MIYAKE).

Dimensions (in $\mathrm{mm}$ ):

Length of carapace

4.2

Breadth of carapace

Length of wrist

Breadth of wrist

5.1

Length of palm

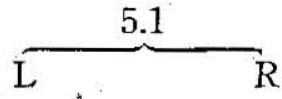

Breadth of palm

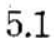

4.5

3.0

2.5

Length of movable finger

Distribution: China Sea, Amakusa.

33. Polyonyx utinomii nom. nov.

Text-figs. $\quad 58-59$.

Polyonyx asiaticus Mryake 1937, p. 216 (not P. asiaticus Shen, 1936).

Carapace much broader than long, the proportion of length to breadth being $1: 1.42$; upper surface strongly convex longitudinally, smooth, glabrous and transverse lineolate near the lateral margins; regions faintly indicated. Front rather broad, measuring one-third as long as the carapace; median lobe a little more projecting than lateral lobes. Antero-lateral margin of carapace cut into two arcs by a broad sinus above the base of antenna; posterolateral margin rounded; posterior margin slightly concave.

First peduncle of antennule smooth, very thickened distally; upper plate much concave laterally; antero-inner lobe not produced than the upper plate; the lateral margins much convergent basally. First peduncle of antenna very broad, elongated; upper plate elliptical, with the surface more or less concave. Succeeding peduncles cylindrical and smooth. The relative lengths of basal peduncles are II $: \mathrm{III}: \mathrm{IV}=5: 8: 4$. Third maxilliped smooth, with each segment very long; the inner crest of merus broad, rounded and almost symmetrical. The sternum of third maxilliped shorter 
than the anterior margin of thoracic sternum, the proportion of them being 7:8. Anterior margin of sternum of third maxilliped more or less convex, being destitute of middle process; outer margin of the lateral process straight. Anterior margin of thoracic sternum strongly concave especially near the middle.

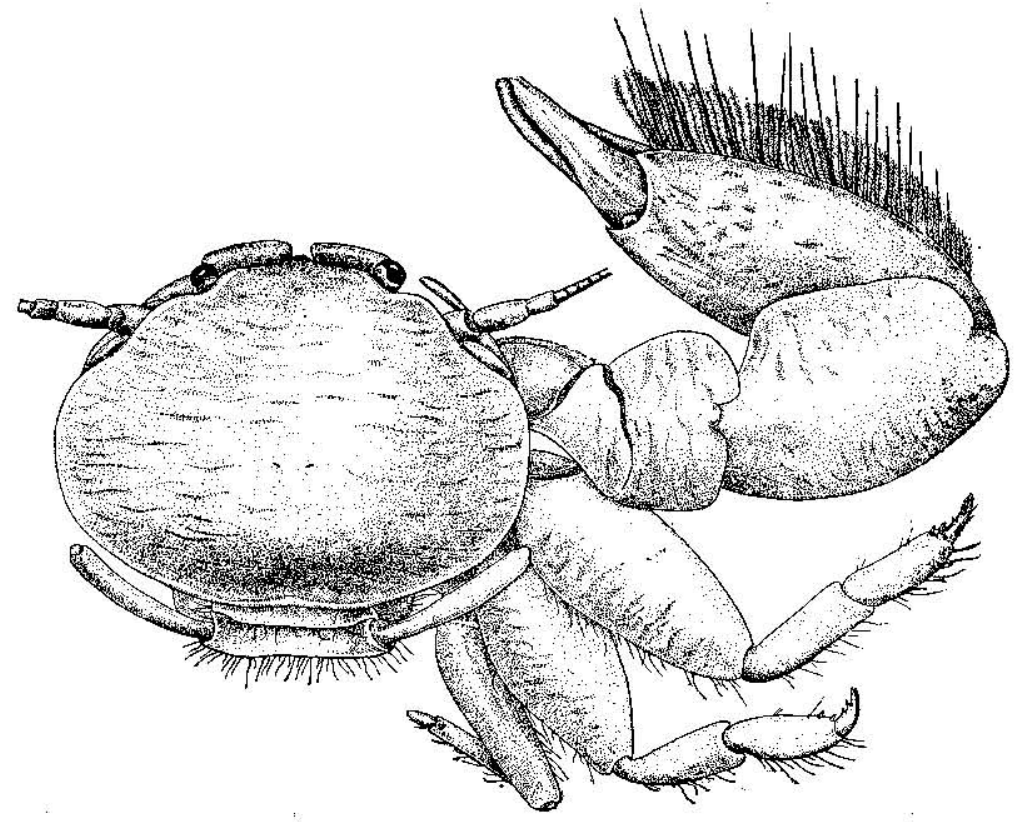

Fig. 58. Polyonyx utinomii nom. nov., female, $\times 12$.

Chelipeds unequal, the right one being larger in the holotype. Arm and wrist convex, smooth, though marked with some delicate transverse lines which are only visible by means of a magnifying lens on upper surface; their anterior margins project in the form of a crest, forming a deep concavity beneath for the reception of the inner part of palm. The crest of merus broad and rounded, that of wrist with straight free margin, not swollen; palm marked with short, microscopical longitudinal lines on upper surface and furnished with a line of stiff hair thickly on lower margin. Movable finger provided with a line of granules on outer surface, cutting edges of both fingers armed with small teeth.

Ambulatory legs successively decrease in length; merus very broad; carpus unarmed; propodus armed with three spinules on 
posterior margin: two of them in pair at distal end, remaining one just in front of them; dactylus terminates in a double claw, accessory claw above much smaller than principal one, in addition to them it bears two spinules on posterior margin. Telson of abdomen seven-jointed, central plate rather narrow.

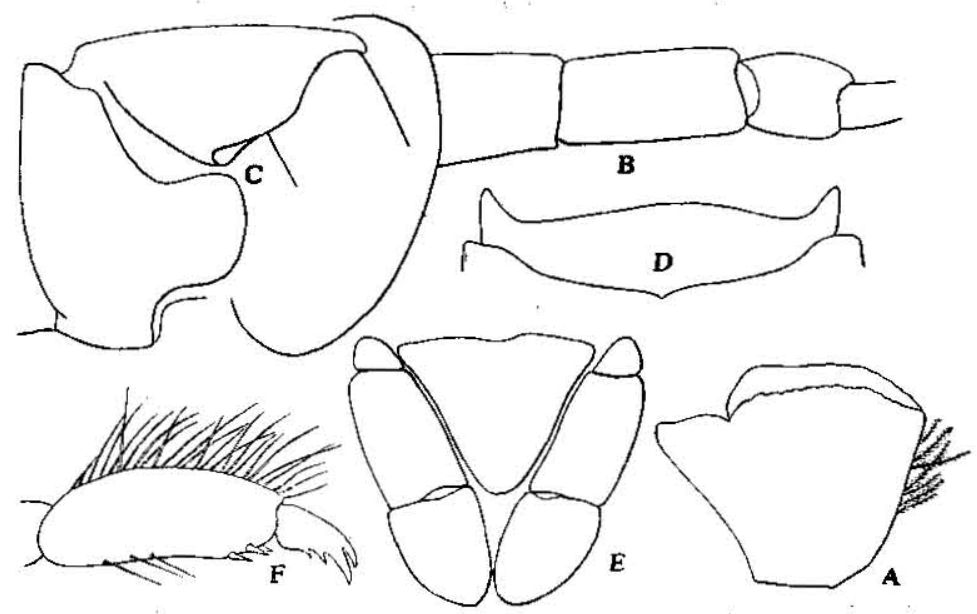

Fig. 59. Polyonyx utinomii nom. nov.

A First peduncle of left antennule, ventral view, $\times 40, \quad$ B Basal peduncles of right antenna, dorsal view, $\times 40, \mathrm{C}$ Merus and carpus of third maxilliped of right side, $\times 40, \quad \mathrm{D}$ Sternum of third maxilliped of right side, $\times 25$, E Telson of female, $\times 25, \quad F$ Dactylus and propodus of ambulatory leg, $\times 25$.

Remarks: This species is allied to P. asiaticus SHEN, 1936, but differs from it in shape of the crest of wrist, which is not so swollen as in that species. The crest of merus of third maxilliped is broader than that of $P$. asiaticus, and moreover, propodus bears only three spinules instead of four.

In my previous paper (MTYAKE 1937 $\mathrm{d}$ ), I referred a specimen from Seto, Prov. Kii to Polyonyx asiaticus SHEN from Chefoo, North China, but with some doubt as to its identification. However, after my closer investigation, I think it better at present to separate the Nipponese form from the Chinese as a distinct species.

Colour in alcohol: : Whitish.

Habitat: Commensal in Chaetopterus variopedatus. 
Material examined: Tanosaki, Prov. Kii; $1 \hat{\delta}$, S.M.B.L., IX J. Cat. No. 20, Apr. 20, 1927 (Utinomi).

Dimensions (in $\mathrm{mm}$ ):

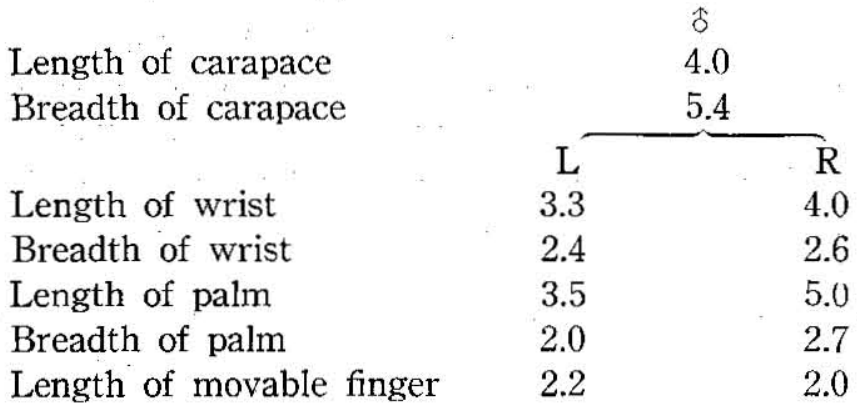

\section{Polyonyx carinatus ORTMANN}

Polyonyx carinatus ORTMann 1892, p. 268, Pl. 12, figs. 2, 2 e.

I have not had an occasion yet to examine this species. The following diagnoses were prepared from ORTMANN's original descriptions.

"Carapace rounded, not longer than broad, smooth, but somewhat hairy. Front short, almost straight, slightly produced only in the middle and with a faint median groove above. Chelipeds subequal, merus armed with a triangular tooth on distal end of inner margin, wrist with a longitudinal edge on upper surface and armed with one or two teeth on anterior margin, palm with a longitudinal edge on upper surface, its inner margin provided with two spines at distal end, its outer margin with a row of hairs, movable finger with a feeble longitudinal edge, dactylus terminates in two unguicles, the accessory claw of which being smaller than the principal one and tubercle-like."

Distribution: Amami-Ōsima (Type-locality).

\section{Polyonyx biunguiculatus (DANA) Text-fig. $60 .^{\circ}$}

Porcellana biunguiculata DANA 1852 , p. $411 ; 1855$, Pl. 26, fig. 1Locality unknown.

HaSwell 1882, p. 147-Off Port Denison, Queensland. Polyonyx biunguiculatus GoRDon 1935, p. 10, figs. 5b-d-Eiland Enoe. 


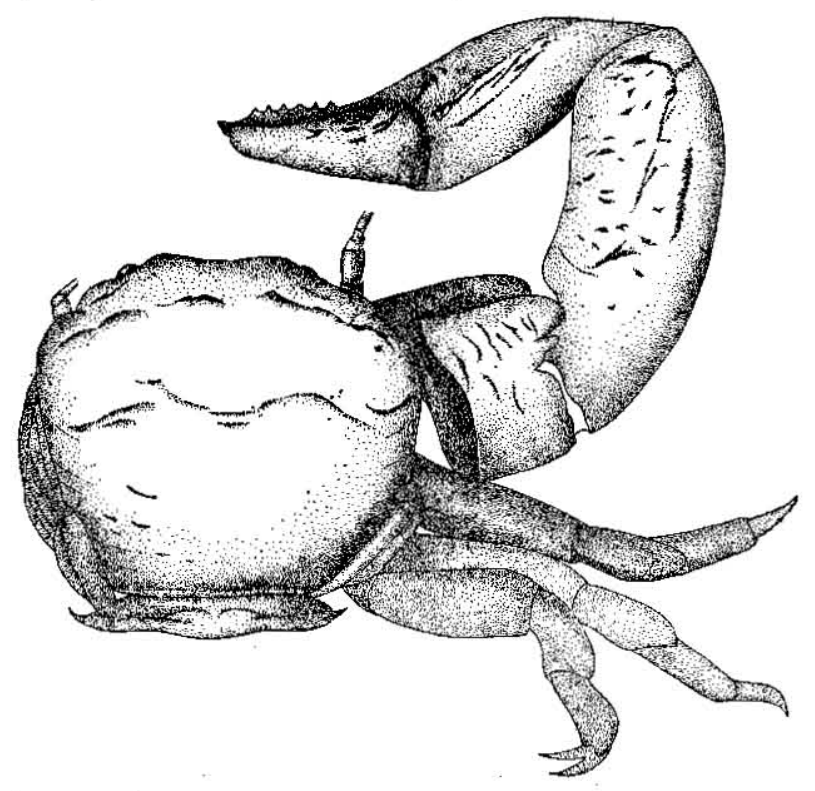

Fig. 60. Polyonyx biunguiculatus (DANA), male, $\times 7.5$.

Genus Raphidopus STIMPson

Raphidopus StIMPSON 1858, p. 66; 1907, p. 184 ; HeNDERSON 1888, p. 113.

The forms of the carapace, chelipeds, and ambulatory legs render this one of the most distinct genera in the Porcellanidae. Carapace suborbicular, broader than long, and much expanded at the sides. Front transverse, not prominent, and dentate. Eyes of small size. First peduncle of antenna elongated, jointing the upper margin of carapace. The third maxilliped of usual form; ischium, however, is short, very much dilated and rounded within, and its external apex not rounded. Chelipeds elongated, with narrow curved digits. Ambulatory legs slender, the dactyli flattened and ciliated, almost straight, with the apex sharply pointed, but without any indication of a distinct unguicle. Such a form of legs seems to be well adapted for moving about with ease through soft mud in which it lives. 
Type: Raphidopus ciliatus STIMPSON

Following two species have hitherto been described: 1. R. ciliatus Stimpson, 2. $R$. indicus Henderson from Madras, India.

36. Raphidopus ciliatus STIMPSON

. Text-figs. 61-62.

Raphidopus ciliatus STIMPSON 1858, p. 241; 1907, p. 185, Pl. 22, fig. 5-Hongkong (Type-locality).

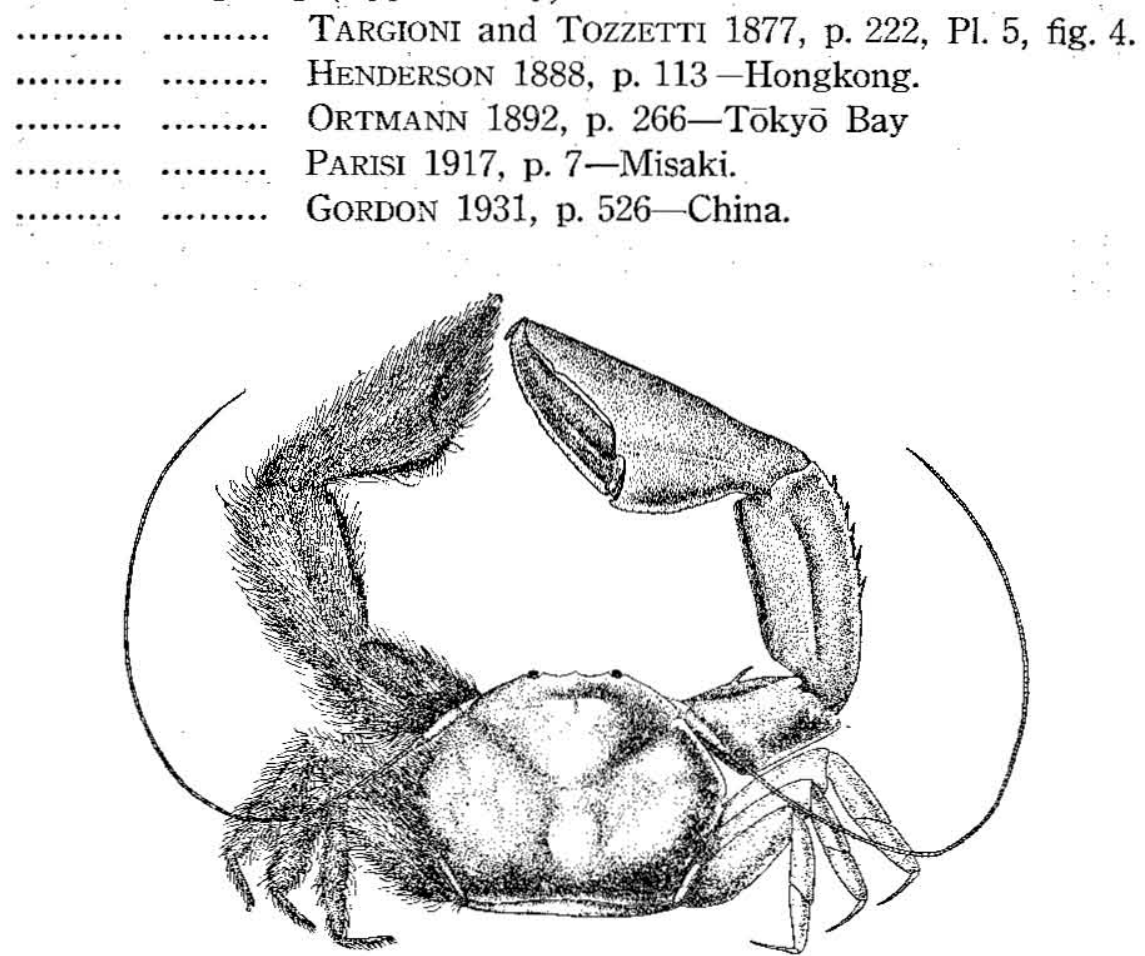

Fig. 61. Raphidopus ciliatus Strmrson, male, $\times 5.3$.

Sides of the body and margins of the legs thickly ciliated with long, fine hairs. Carapace rounded, broader than long, tomentum somewhat areolated; surface slightly uneven and transversely rugate especially on latero-inferior regions. Lateral margin strongly convex, with a sinus behind base of antenna at the position of epibranchial tooth in members of Petrolisthes, two small teeth or spines near the middle, and a spine on the postero-lateral margin 
at the extremity of a short oblique ridge. Frontal margin not produced, divided into three minute teeth, the median one most prominent. Antero-lateral margin slightly sinuated at the orbits.

First peduncle of antennule is tuberculated on anterior region, and ciliated on anterior margin. Antenna cylindrical and ciliated on the surface. Second peduncle provided with a small tubercle. The relative lengths of basal peduncles are II:III:IV= $5: 7: 3$. Merus of third maxilliped smooth, somewhat punctate on ventral surface. The laminate crest provided with rounded free margin.

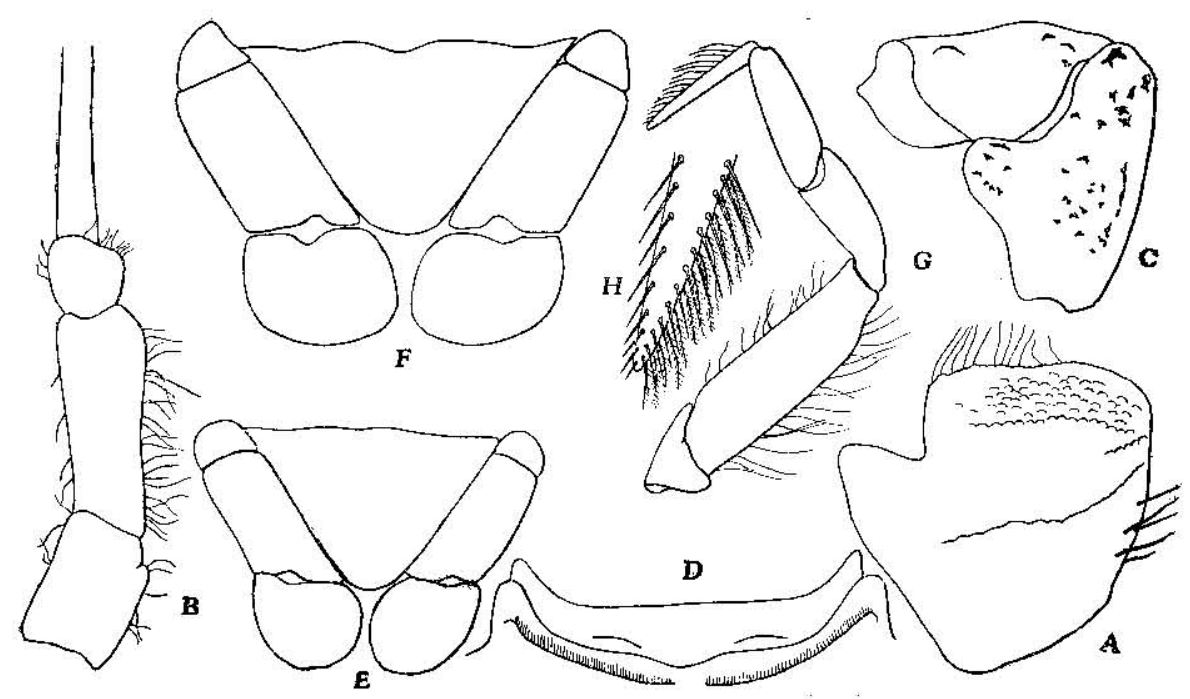

Fig. 62. Raphidopus ciliatus Strmpson.

A First peduncle of left antennule, ventral view, $\times 25, \quad$ B Basal peduncles of left antenna, ventral view, $\times 12, \quad \mathrm{C}$ Merus and carpus of third maxilliped of left side, ventral view, $\times 12, \quad D$ Sternum of third maxilliped of ovigerous female, $\times 7.5, \quad E$ Telson of male, $\times 12, \quad F$ Same of ovigerous female, $\times 7.5, \quad$ G Second ambulatory leg of left side, $\times 12, \quad H$ Dactylus of same, $\times 25$.

Chelipeds unequal, angular and very hairy; arm large, more than two-thirds as long as the wrist, with a longitudinal ridge on upper surface and armed with a single, sharp, curved spine on inner margin; wrist nearly as long as palm, with a median 
logitudinal spinulated ridge, its anterior margin not dilated, slightly concave and serrulated; its posterior margin convex and armed with four or five spinules; smaller palm elongated, subtriangular, with three longitudinal obtuse ridges, minutely crenulated or spinulated on the upper surface; fingers longer than palm, not gaping, tips much curved, crossing each other, cutting edges minutely denticulated but not toothed; inner edge of immovable finger slightly dilated. In the larger hand movable finger subcristate above, and armed with a tooth near the base on cutting margin; the immovable finger bears a strong tooth at the middle of cutting margin.

Ambulatory legs long, slender, slightly compressed; merus not dilated; dactylus as long as propodus, and slightly sulcated on one side toward extremity; dactylus of third pair shorter than the others. Telson of abdomen seven-jointed; its postero-lateral plate large, broader than long specially in female.

Colour in life: Body white; hairs yellowish brown.

Habitat: Taken with a trawl on muddy bottom at 1-6 fathoms.

Material examined:

Bingo-Nada, Inland Sea, 1 ô, 4 ovig. 우 우, Sept. 22, 1933 (TAKI).

Tomioka, Amakusa, 1 ovig. o, Sept. 10, 1934 (MIYAKE).

Dimensions (in $\mathrm{mm}$ ):

\begin{tabular}{|c|c|c|c|c|}
\hline $\begin{array}{l}\text { Length of carapace } \\
\text { Breadth of carapace }\end{array}$ & \multicolumn{2}{|c|}{$\begin{array}{c}3 \\
5\end{array}$} & & \\
\hline Length of wrist & 5.0 & 5.0 & 9.0 & 8.0 \\
\hline Breadth of wrist & 2.8 & 3.0 & 5.0 & 4.0 \\
\hline Length of palm & 5.0 & 6.0 & 6.0 & 8.8 \\
\hline Breadth of palm & 3.3 & 4.0 & 7.0 & 6.0 \\
\hline Length of immovable finger & 3.8 & 3.8 & 6.8 & 6.5 \\
\hline
\end{tabular}

Distribution: Tōkyō Bay, Misaki, Inland Sea, Amakusa, Hongkong.

\section{ZOOGEOGRAPHICAL AND ECOLOGICAL NOTES}

The forms of Nipponese Porcellanids, as far as known, are referable to 36 species and one variety. One of them Pachycheles 
stevensii STIMPSON is regarded as belonging to the northern group (2.8 per cent.), distributed from Vladivostock, Hokkaido, Nippon proper to the Inland Sea, while the others all inhabit in temperate or subtropical seas. These latter may be divided from the distributional and ecological view-point into three groups as follows:

\section{i. Common to Nippon proper and Hongkong}

( 6 species, 16. 6 per cent.)

This group inhabits in temperate zone, especially first two species are restricted in Nippon proper; they are considered as endemic species of Nippon. The last four species are distributed in Nippon proper, Hongkong and its neighbourhood in South China, being regarded as the Far Eastern species. The discontinuous range between Kyüsyu and Hongkong seems to be due to unfavourable habitat. HiRo's suggestion as to Cirripedia of the discontinuous distribution seems to be related closely to our case.

Table 1. Distributional list of first group

\begin{tabular}{|c|c|c|c|c|c|c|c|c|}
\hline \multirow[t]{2}{*}{ Species } & \multicolumn{7}{|c|}{ Localities } & Habitats \\
\hline & 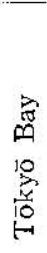 & 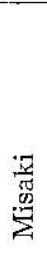 & 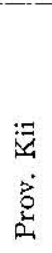 & 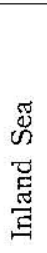 & 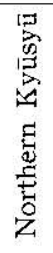 & 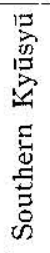 & 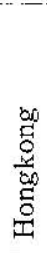 & \\
\hline 1. Pachycheles balssi & - & 0 & 0 & - & 0 & - & - & under stones \\
\hline 2. Polyonyx utinomii & - & 一 & 0 & - & - & - & - & commensal \\
\hline 3. Raphidopus ciliatus & 0 & $\rightarrow$ & - & 0 & 0 & $\mathrm{O}$ & 0 & muddy bottoms \\
\hline 4. Porcellana ornata & - & - & 0 & 0 & 0 & 0 & 0 & muddy bottoms \\
\hline 5. P. pulchra & 一 & 一 & 一 & 0 & 0 & - & 0 & commensal \\
\hline 6. Polyonyx sinensis & - & 一 & $\rightarrow$ & 一 & - & 0 & 0 & free living \\
\hline
\end{tabular}

Polyonyx utinomii MrYake is a commensal living in the Chaetopterus tube. ENDERS, SHELFORD and PEARSE have observed a peculiar mode of life. 
Polyonyx macrocheles (GIBBES) associated with Chaetopterus. P. macrocheles, after their statements, is strongly thigmotaxic and creeps into crevices or tubes; it becomes quiet when shadows pass over the body, it feeds by "net casting" after the manner of barnacles; it has a very long breeding season, producing one brood after another. The thigmotaxis would easily account for its entering host's tubes, and its feeding habit is admirably suited for the capture of food in such a situation. The quick cessation of motion when stimulated by a decrease in light might protect them from enemies when out of the tube.

A pair of Porcellana pulchra STIMPSON lives commensalistic with a hermit crab Pagurus haani (RATHBUN), occupying a shell of Rapana thomasiana CROSSE. A few Syphopatella walshi (REEVE) with white shell are attached to the inner face of shell. A similar mode of a peculiar association is also found in the case of Porcellana paguriconviva GLASSELL. In the Gulf of California, this Porcellanid is a commensal living with a large hermit crab Petrochirus californiensis BouvIER. The usual association is: the Pagurid host, occupying the shell of Phyllonotus nigritus (PHILIPPI), accompanied by a large Pollonoid worm and a pair of $P$. paguriconviva. At times the inner face of the shell may find a Crepidula nivea Gould attached, and this in turn may have its own Pinnotherid commensal Fabia granti GLASSELL.

ii. Indo-Malayan species commonly inhabiting in warmer waters of Nippon.

(11 species, 30.6 per cent.)

This group is commonly found in Nippon proper, South-West Islands, Hongkong, and also in the Indo-Malayan, South Pacific Seas; it was seldom obtained in North Australia, Hawaii Islands, and farther westward to the Red Sea.

These species are evidently recognised to belong to the IndoMalayan fauna, and may be considered to have propagated to the northern temperate zone driven by the warm current or Kurosio. These species have their northern limits of distribution in Tökyō Bay or Kominato, two of them living as commensals. The remainder are free-living, littoral inhabitants.

Porcellana serratifrons STIMPSON usually lives among fouling animals of ships' bottoms in the waters of Kyūsyū. Ships' bottoms 
are primarily occupied by a barnacle Balanus amphitrite, a tubicolous Polychaete Hydroides norvegica MARENZELLER and some Bryozoa. This little Porcellanid lives among the named fouling animals being accompanied by a crab Sphaerozius nitidus Stimpson. This secondary association seems to owe to their feeding habits. Ac-

Table 2. Distributional list of second group

\begin{tabular}{|c|c|c|c|c|c|c|c|c|c|c|c|c|}
\hline Localities & 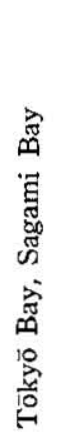 & 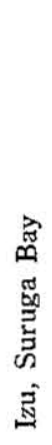 & $\begin{array}{l}\text { 涪 } \\
\dot{0} \\
\text { 品 }\end{array}$ & 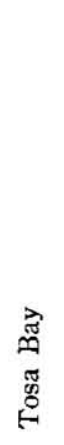 & $\begin{array}{l}\mathbb{J} \\
\tilde{n} \\
\vec{\Xi} \\
\mathbb{\Xi}\end{array}$ & 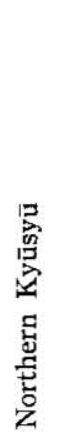 & & 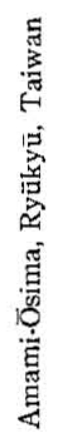 & 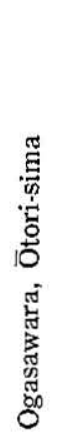 & 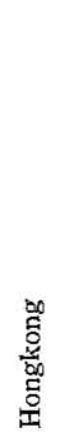 & 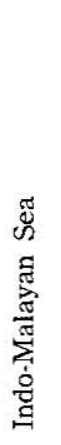 & 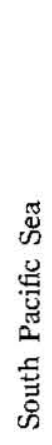 \\
\hline 1. Petrolisthes japonicus & 0 & 0 & 0 & - & 0 & 0 & 0 & 0 & - & 0 & 0 & - \\
\hline 2. P. coccineus & 0 & - & 0 & 0 & - & 0 & 0 & 0 & - & - & 0 & 0 \\
\hline 3. P. boscii & 一 & 0 & 0 & 0 & - & - & 0 & - & - & - & 0 & - \\
\hline 4. Porcellanella picta & - & - & 0 & 0 & 0 & - & - & - & - & 0 & 0 & - \\
\hline 5. Porcellana serratifrons & - & - & - & - & 0 & 0 & 0 & - & - & 0 & 0 & 0 \\
\hline 6. Petrolisthes hastatus & 一 & - & - & - & - & - & 0 & 0 & - & - & 0 & - \\
\hline 7. P. indicus & - & 一 & 一 & - & - & - & - & 0 & 0 & - & 0 & - \\
\hline 8. P. tomentosus & - & - & - & - & 一 & - & 0 & 0 & 0 & - & - & 0 \\
\hline 9. P. masakii & - & - & - & - & - & - & - & 0 & - & 一 & - & - \\
\hline 10. Polyonyx carinatus & - & - & - & - & - & - & - & $\mathrm{O}$ & - & - & - & - \\
\hline 11. Pisosoma fronto & - & - & - & - & - & - & - & 0 & 0 & - & - & - \\
\hline
\end{tabular}

cording to NICOL, the well-developed mouth-part of the majority of the Decapoda shows that they were originally carnivorous, feeding on large food masses. Departures from the normal methods of obtaining food are entirely secondary, and the feeding habits have developed independently in various groups, often in connection with 
peculiar habits. These Porcellanids feed on the larvae of Polychaetes and Molluscs.

Porcellanella picta STIMPSON is usually found attached to leaves of Pteroeididae. Its peculiar colour-markings as well as unguicles of dactylus are adapted for the commensal life.

The remainder are free-living, littoral forms. They are adapted to sedentary life in crevices and under stones, and can still creep rapidly on a substratum, walking backwards, but never forwards, and sometimes attempt to swim in feeble manner by flapping their tail. Some of them, however, have become still more sedentary, scarcely moving, relying on protective form and coloration for safety.

The last three species are inhabiting in the coral reefs of Southern Nippon. I have not examined the last mentioned form. $P$. indicus DE MAN is found under stones at extreme low tide. $P$. fronto (MeLrN) usually inhabits under rocks of barrier reefs.

iii. Subtropical and tropical forms living in coral reefs

(18 species, 50 per cent.)

This group is commonly found in coral reefs of subtropical and tropical seas in the Indo-Pacific region. These species are roughly divided into the following three subgroups from their distributional phase.

1. The forms widely distributed in the Indo-Pacific region contain four species, namely Petrolisthes asiaticus (LFACH), $P$. penicillatus (Heller), Pisosoma sculptum (H. Milne-Edwards), Petrolisthes lamarckii var. rufescens (Heller). Amami-Osima is regarded as their northern limit, while only one species, $P$. asiaticus spreads to Kagosima Bay.

2. The species inhabiting in the Indo-Malayan, South Pacific and North Australian Sea are eight in number, referable to five genera as enumerated in the following list. 1. Fisosoma pisum (H. MiLNEEDWARDS), 2. Petrolisthes lamarckii (LEACH), 3. P. moluccensis DE Man, P. militaris (Heller), 5. Porcellana suluensis Dana, 6. P. armata (DANA), 7. Porcellanella triloba White and 8. Polyonyx biunguiculatus (DANA).

Among these, the first three species inhabit the breaker zone of coral reefs exposed to strong tides. The remaining five species 
are found among submerged corals. Porcellana suluensis and $P$. armata are attached themselves to stagshorn corals at reef margins. Porcellanella triloba is commensal with leaves of Pteroeides as $P$. picla is. Usually a single pair occupies one host, but one or three may be present.

Table 3. Distributional list of third group

\begin{tabular}{|c|c|c|c|c|c|c|c|}
\hline Localities & 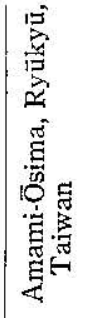 & 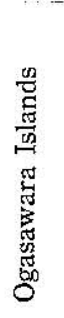 & 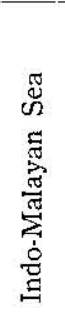 & 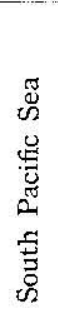 & 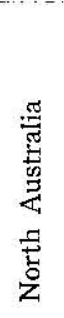 & 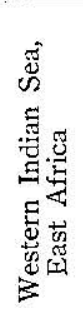 & 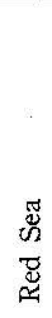 \\
\hline 1. Petrolisthes asiaticus & 0 & - & O & 0 & 0 & 0 & - \\
\hline 2. P. penicillatus & 0 & - & O & 0 & - & 0 & - \\
\hline 3. Pisosoma sculptum & 0 & - & 0 & 0 & - & 0 & 一 \\
\hline 4. Petrolisthes lamarckii var. rufescens & 0 & - & - & 0 & - & - & 0 \\
\hline 5. P. lamarckii & 0 & 0 & 0 & 0 & 0 & - & - \\
\hline 6. P. moluccensis & 0 & - & 0 & 0 & - & - & - \\
\hline 7. P. militaris & 0 & - & 0 & - & 0 & 一 & - \\
\hline 8. Porcellana suluensis & - & - & 0 & 0 & 0 & - & - \\
\hline 9. P. armuta & 0 & - & 0 & 0 & 0 & - & - \\
\hline 10. Pisosoma pisum & O & - & 0 & - & 0 & - & - \\
\hline 11. Porcellanella triloba & - & - & 0 & 0 & 0 & - & 一 \\
\hline 12. Polyonyx biunguiculatus & - & - & 0 & 0 & 0 & - & - \\
\hline 13. Petrolisthes unilobatus & O & - & - & o & - & - & - \\
\hline 14. P. fimbriatus & $\mathrm{O}$ & - & - & 0 & - & - & - \\
\hline 15. P. inermis & - & 0 & 一 & - & O & - & - \\
\hline 16. Neopetrolisthes ohshimai & 0 & - & - & 0 & 0 & - & 一 \\
\hline 17. Porcellana nitida & - & - & - & 0 & 0 & - & - \\
\hline 18. P. murakamii & - & - & - & 0 & - & - & - \\
\hline 19. P. melissa & - & 一 & - & 0 & - & - & - \\
\hline
\end{tabular}


3. These species are commonly distributed in South Pacific waters or Northern Australia, containing the following seven species. i.e. 1. Petrolisthes unilobatus HeNDERSON, 2. P. fimbriatus Borradaile, 3. P. inermis Haswell, 4. Neopetrolisthes ohshimai Mryake, 5. Porcellana nitida DANA, 6. P. murakamii Mryake and 7. P. melissa MiYAKE.

Petrolisthes unilobatus inhabits under stones of exposed reef flat in low tide, occasionally associated with Petrolisthes asiaticus. Porcellana nitida lives attached to soft coral of submerged reefs.

Neopetrolisthes ohshimai is commonly found residing commensally in the oral cavity of a gigantic sea-anemone Stoichactis kentii (HADDON and SHACKLETON), which measures 15 to $40 \mathrm{~cm}$ in diametre, seldom also inside Stoichactis haddoni (SAville-KenT). In the host animal, a single pair of the Porcellanid is associated with a couple of the prawn Periclimenes (Ancylocaris) brevicarpalis (SCHENKEL) and a few pretty fishes Actinicola percula (LAPCÉPÈDE), or Amphiprion frenatus BREVOORT. In coral reefs of Isigaki Island, in addition to the associates enumerated above, there were found a few snails Coralliophia stearnsii PILSBRY, attached to the outer surface of the body of the anemone.

The body of $P$. brevicarpalis is almost transparent, of a light brown colour with exception of a few parts of the surface which are covered with white and opaque speckles. The speckles of male and female are distinct. A fish Actinicola percula is usually found commensal with the host, it is measured 50 to $80 \mathrm{~mm}$ in total length, having strongly mucous surface; colour in life is yellowish brown with three pearl white cross-bands: first behind the head, second at middle, third around the caudal peduncle. According to AoYAGI (1941), some degenerative tendency is observed in gill raker, teeth and pyloric appendage of this fish.

The poison of the sea-anemone seems to be fatal to other animals. Nothing could be seen in the oral cavities of smaller anemones, say about $15 \mathrm{~cm}$ in diametre, after my obsevation, but a larger one was found to have fed on a crab or some fish. The fish was found dead. The crab had gone into pieces, but it was easily identified as Xantho sanguineus (H. MunE-EDWARDS) by an empty carapace, chelipeds and ambulatory legs. This crab is commonly inhabiting near the host. 
Concerning to poison of the anemone, the writer has assured of the following fact by personal experience. Coming across a coral reef standing out of clean sea-water, where no mangrove is seen, we may notice gigantic sea-anemones Stoichactis kentii, putting out their countles tentacles. The tentacles are tinged with brown, blue and purple, and they look so charming that one feels a temptation to touch them. These feelers have a peculiar nature of getting easily stuck to other objects, and once they get so clung, they will get detached from the body. If one thrusts one's bare hand into the tentacle-crown, the tentacles will stick to the hand firmly and the skin of the hand so touched will later become swollen up and a little pain is felt. The injury will last for a few days. One need not, however, feel uneasy about it, as these tentacles are not very poisonous.

This association, Young states, is more remarkable when it is realised that it is just those types of animals which form the normal food of the anemone. But those particular spccics seem to have developed immunity to the poison of the nettle cells, and probably make a good living out of the pickings from the fond of the anemone.

\section{BIBLIOGRAPHY}

Avyagr, $\mathrm{H}, 19 \mathrm{gi}$ The damsel ńshes in the waters of Japan. Biogeographica, Trans. Biggengr Soc Japan, vol 4 , no 1 . Tonkyō.

BaLss, H. 1913 Ostasiatische Decapoden. I. Die Galatheiden und Paguriden. K. B. Akad. Wiss., math.-phys. Kl., Suppl. Bd. 2, Abh. 9. München.

- 1915 Die Decapoden des Roten Meeres. II. Anomuren, Dromiaceen und Oxystomen. Expeditionen S. M. Schiff „, Pola " in das Rote Meer, Nördliche und Südliche Hälfte, 1895/96-1897/98, Zoologische Ergebnisse, Bd. 31. Wien.

BэrRadalli, L. A. 1898 On some Crustaceans from the South Pacific. Pt. 2. Proc. Zool. Soc., London.

Calman, W. T. 1909 On Decapod Crustacea from Christmas Islands collected by Dr. AnIR:ws. Proc, Zool. Soc., London.

Dana, J. D. 1852 Crustacea of the U. S. Exploring Expedition, and Atlas (1855). Philadelphia.

ENis:R, H. E. 1905 Notes on the Commensals found in the tubes of Chatopterus pergamentaceus. Amer. Nat., vol. 39. New York.

1909 A study of the life-history and habits of Chaetopterus variopedatus Rekier et Cr.Aparidide. Journ. Morph., vol. 20. Boston.

Estampadjo, E. P. 1937 A check list of Philippine Crustacean Decapods. Philippine Journ. Sci., vol. 62. Manila. 
Gordor, I. 1931 Galatheidea: in Brachyura from the coast of China. Journ. Linn. Soc., vol. 37. London.

- 1935 Anomura (excl. Paguridea): in Résultats scientifiques du Voyage aux Indes Orientales Néerlandaises de LL. AA. RR. le Prince et la Princesse Léopold de Belgique. Mém. Mus. Hist. Nat. Belgique, Hors Sér., Tom. 3, Fasc. 17. Bruxelles.

Glassfi.L, S. A. 1936 New Porcellanids and Pinnotherids from Tropical North American Waters. Trans. San Diego Soc. Nat. Hist., vol. 8, no. 21. San Diego. 1938 New and obscure Decapod Crustacea from the West American Coasts. Trans. San Diego Soc. Nat. Hist., vol. 18, no. 33. San Diego.

DE. HAAN, W. 1849 Porcellanidea: in Fauna Japonica, Crustacea. Batavia.

Haswell, W. A. 1882 Catalogue of the Australian stalk- and sessile-eyed Crustacea. Sydney.

Hellek, C. 1862 Beiträge zur Crustaceenfauna des Roten Meeres. II. Anomura und Macrura. S. B. Wiener Akad. Wissenschat., math.-phys. Kl., Bd. 44. Wien.

1865 Crustaceen: in Reise der Novara. Wien.

Henderson, J. R. 1888 Report on the Anomura, collected by the H. M. S. Challenger. Report of H. M. S. Challeger, Zool., vol. 27. London.

- 1893 A contribution to Indian Carcinology. Trans. Linn. Soc., Zool., Ser. 2, vol. 5. London.

Hiro. F. 1939 Studies on the Cirripedian Fauna of Japan. IV. Cirripeds of Formosa, with some geographical and ecological remarks on the littoral forms. Mem. Coll. Sci. Kyōto Imp. Univ., Ser. B, vol. 15, no. 2. Kyōto.

Holmes, S. J. 1900 Synopsis of California stalk-eyed Crustacea. Occasional papers Calif. Acad. Sci., vol. 8. San Francisco.

Kikuchr, K. 1932 Decapod Crustaceans of Toyama Bay. Toyama Kyöiku, 1932.

Lanciestik, W. F. 1900 On some Malacostracous Crustaceans from Malaysia in the collection of the Sarawak Museum. Ann. Mag. Nat. Hist., Ser. 7, vol. 6, no. 33. London.

Lauris, R. D. 1926 Anomura collected by Mr. J. Stanley Garirinir in the western Indian Ocean in H. M. S. "Sealark". Trans. Linn. Soc., Zool., Ser. 2, vol. 19. London.

LENz, H. 1901 Ergebnisse einer Reise nach dem Pacific (Schauinsland 1876-1897). Zool. Jahrb., Syst., Bd. 14. Jena.

McNert, , F. A. and WARD, M. 1930 Carcinological notes. I. Rec. Aust. Mus., vol. 17, no. 3. Sydney.

Marcus, K. 1911 Ueber Geruchsorgane bei Decapoden aus der Gruppe der Galatheiden. Zeitsch. Wiss. Zool., Bd. 97. Leipzig.

DE MAN, J. G. 1888a Report on the Podophthalmous Crustacea of the Mergui Archipelago, collected for the Trustees of the Indian Museum, Calcutta, by Dr. J. Annerson, F.R. S., Superintendent of the Museum. Part 4. Journ. Linn. Soc., vol. 22. London.

-.. 1888b Decapoden und Stomatopoden. Arch. Naturg., Jg. 53. Berlin.

1892 Decapoden des Indischen Archipels. Zoologische Ergebnisse einer Reise in Niederländisch Ost-Indien, Bd. 2. Leiden.

1893 Report on the podophthalmous Crustacea, collected in the year 1891 by 
Dr. H. Ten Kate in some islands of the Malay Archipelago. Notes from the Leyden Museum, vol. 15. Leyden.

Ie Man, J. G. 1896 Bericht über die von Storm zu Atjeh, den westlichen Küsten von Malacca, Borneo und Celebes sowie in der Javasee gesammelten Decapoden in Mus. Lübeck. Zool. Jahrb., Syst., Bd. 9. Jena.

19.92 Die von Prof. Küknntial in Indischen Archipel gesammelten Decapoden und Stomatopoden. Abh. Senckenb. Naturf. Ges., Bd. 25, Heft 3. Frankfurt a. $\mathrm{M}$.

Mli IK, G. 1939 Paguriden und Galatheiden von Prof. Dr. Sixten Bocks Expedition nach den Bonin-Inseln 1914. Kungl. Svenska Vetenskaps- Akad. Handl., Tredje Ser., Bd. 18, No: 2. Stockholm.

Mrers, J. E. 1879 On Crustacea from the Corean and Japanese Seas. Proc. Zool. Soc. London.

- 1884 Crustacea H. M. S. "Alert". London.

Mrsni:-Emarns, A. 1873 Description de quelques Crustacés nouveau ou peu connus provenant de Musée de M. C. Godeffroy. Journ. Mus. Godeffroy, Bd. 1, Heft 4. Hamburg.

Milne-Edwards, H. 1837 Tribu des Porcellaniens: in Histoire Naturelle des Crustacés, Tom. 2. Paris.

Miyake, S. 1937a A new crab-shaped Anomura living commensally with a gigantic sea-anemone (Neopetrolisthes ohshimai gen. et sp. nov.). Zool. Mag., vol. 49, no. 1. Tōkyō.

— 1937b Description of a new species of Petrolisthes from Yaéyama-Group, Riukiu Islands (Anomura, Porcellanidae). Zool. Mag., vol. 49, nos. 3-4. Tökyö. - 1937c Note on Petrolisthes yaeyamensis sp. nov. (Anomura, Porcellanidae). Zool. Mag., vol. 49, nos. 3-4 Tōkyō.

— $1937 \mathrm{~d}$ Porcellanids from Tanabe Bay. Annot. Zool. Japon., vol. 13, no. 3. Tōkyō.

- 1940 Various kinds of crabs in the South Sea Islands under Japanese mandate. Buil. South Sea Assoc., vol. 3, no. 6. Tōkyō.

— 19:2 Studies on the Decapod Crustaceans of Micronesia. III. Porcellanidae. Palao Trop. Biol. Stat. Stud., vol. 2, no. 3. Tōkyö.

Nicol, A. T. 1932 The feeding habits of the Galatheidea. Journ. Mar. Biol. Assoc., N. S., vol. 18, no. 1. Plymouth.

Noвı,I, G. 1905a Decapodes nouv. de côtes d'Arabie et du Golfe Persique. Bull. Mus. Hist. Nat., Tom. 11. Paris.

— 1905b Diagnoses préliminaires dc 34 espèces et variétés nouvelles et de 2 genres nouveaux de Décapodes de la Mer Rouge. Bull. Mus. Hist. Nat., Tom. 11. Paris.

1906 Crustacés et Stomatopodes. Bull. Sci. de la France et de la Belgique, Tom. 40. Paris.

Ortmans; A. E. 1892 Die Decapoden Krebse Strassburger Museums. II. Zool. Jahrb., Syst., Bd. 6. Jena.

1894 Crustaceen: in Semons Zoologische Forschungsreisen in Australien und dem Malayischen Archipel. Denkschr. Medizin.-naturw. Ges., Bd. 8. Jena.

- 1897 Carcinologische Studien. Zool. Jahrb., Syst., Bd. 10. Jena.

Parisi, B. 1917 I Decapodi giapponesi del Museo di Milano. V. Galatheidea e Reptantia. Atti della Soc. Ital. Sci. Nat, vol. 56. Milano. 
Pearse, A. S. 1913 On the habits of the Crustaceans found in Chaetopterus tubes at Hoods Hole, Massachusetts. Biol. Bull., vol. 24. Hoods Hole.

Ricitrers, F. 1880 Decapoda, Porcellanidea: in Beiträge zur Meeresfauna der Insel Mauritius und der Seychellen. Berlin.

Ratition, M. J. 1910 Decapod Crustaceans collected in Duch East India and elswhere by Mr. Thomas Borkot: in 1906-1907. Bull. Mus. Comp. Zoöl., vol. 52. Cambridge, U.S.A.

— 1924 Results of Dr. E. Mü̈вtra's Swedish Scientific Expeditions to Australia 1910-1913. Brachyura, Albuneidae and Porcellanidae. Arch. Zool, Bd. 16. Stockholm.

Schmit, W. L. 1921 The Marine Decapod Crustacea of California. Univ. California Public. Zool., vol. 23. Berkeley, California.

Srand, fr, A. 1923 Die Decapoden und Stomatopoden der Hanseatischen Suidsee. Expedition. Abh. Senckenb. Naturf. Ges. Bd. 38, Heft 1. Frankfurt a. M.

Sirerford, V. E. 1911 Physiological Animal Geography. Journ. Morph., vol. 22. Boston.

SHen, C. J. 1936 Notes on the genus Polyonyx (Porceilanidae) with description of a new species. Bull. Fan Memorial Inst. Biol., Zool., vol. 6, no. 6. Peking.

Strmpson, W. 1858 Prodromus descriptionis animalium evertebratorium, quae in expeditione an Oceanum Pacificum Septentrialem, Observavit et descripsit. Proc. Acad. Nat. Sci., vol. 10. Philadelphia.

- 1907 Report on the Crustacea of the North Pacific exploring Expedition 1853-56. Smiths. Misc. Coll., vol. 49, no. 1717. Washington.

WALKER, A. O. 1890 Note on a collection of Crustacea from Singapore. Journ. Linn. Soc., vol. 20. London.

YoKoYs, Y. 1928 Report of the Biological Survey of Mutsu Bay. 10. Brachyura and Crab-shaped Anomura. Sci. Rep. Tōhoku Imp. Univ., Ser. 4, vol. 3. Sendai.

-_ 1933 Porcellanidae: in On the description of Decapod Crustaceans inhabiting the continental shelf around Japan, chiefly based uppon the materials collected by S.S. Sôyô-Maru, during the years 1923-1930. Journ. Coll. Agr. Tókyö Imp. Univ., vol. 12 , no. 1 . Tōkyô.

- 1936 Some rare and new species of Decapod Crustaceans found in the vicinity of the Misaki Marine Biological Station. Japan. Journ. Zool., vol. 7, no. 1. Tōkyō.

- 1939 Macrura and Anomura of Decapod Crustacea found in the neighbourhood of Onagawa, Miyagi-ken. Sci. Rep. Tōhoku Imp. Univ., Ser. 4, vol. 14, nos. 2-3. Sendai.

Younc, C. M. 1930 A year on the Great Barrier Reer. London.

Zlintwis, L. 1894 Crustaces de l'Archipel malais Voyage de MM. M. BАDot et Ch. Picter dans l'Archipel malais. Revue suisse Zool. et Ann. Mus. d'Hist. Nat. de Genève, Tom. 2. Genève. 